\title{
Navigating Civic Space in a Time of Covid:
}

Synthesis Report

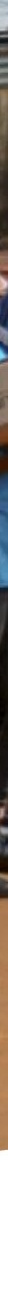

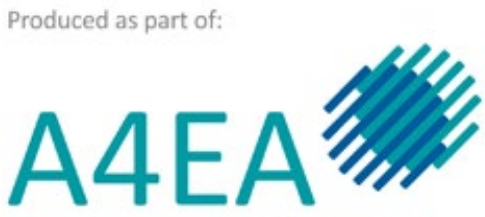

Action for empowerment and accountability research programme
(2) institute of development studies
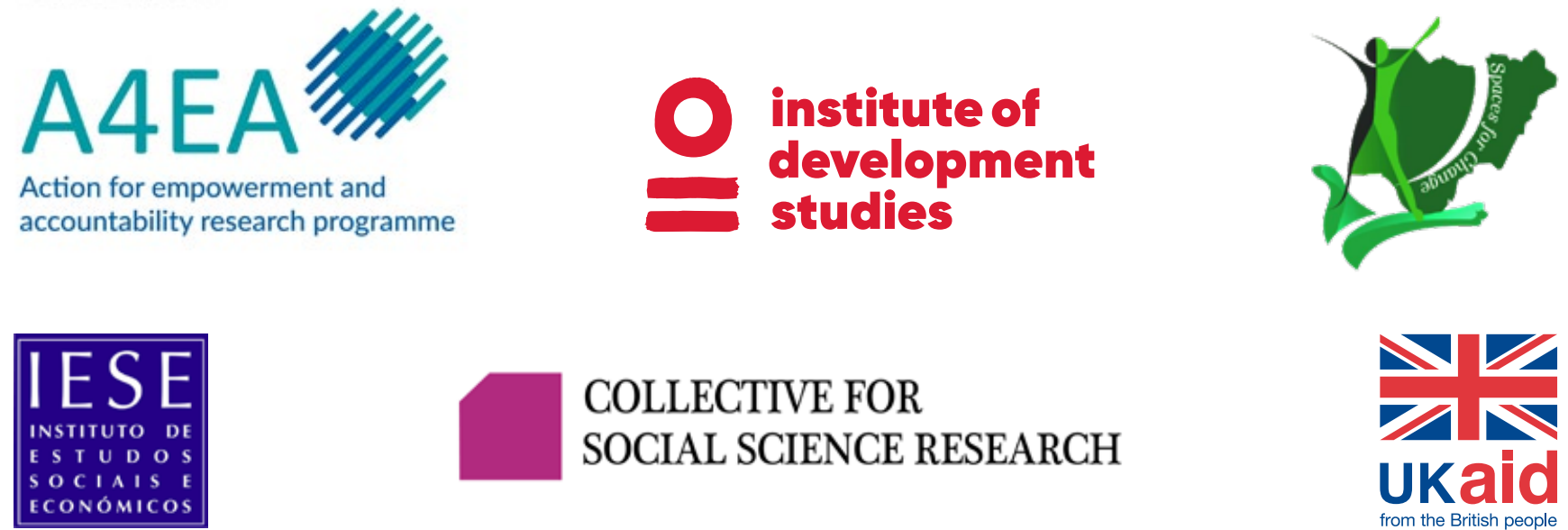

COLLECTIVE FOR SOCIAL SCIENCE RESEARCH

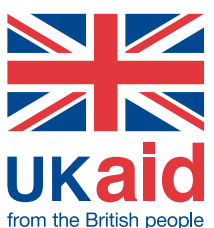




\begin{abstract}
About A4EA
Action for Empowerment and Accountability (A4EA) is an international research programme which explores how social and political action can contribute to empowerment and accountability in fragile, conflict, and violent settings, with a particular focus on Egypt, Mozambique, Myanmar, Nigeria, and Pakistan.

Led by the Institute of Development Studies, A4EA is being implemented by a consortium which includes: the Accountability Research Center, the Collective for Social Science Research, the Institute of Development and Economic Alternatives, Itad, Oxfam GB, and the Partnership for African Social and Governance Research. It is funded with UK aid from the UK government (Foreign, Commonwealth \& Development Office - FCDO, formerly DFID). The views expressed in this publication do not necessarily reflect the official policies of our funder.
\end{abstract}

\title{
About our research team
}

Rosie McGee, Alex Shankland, Niranjan J. Nampoothiri, John Gaventa, and Colin Anderson work at the Institute of Development Studies (IDS). IDS is a global research and learning organisation based at the University of Sussex, UK. It delivers world-class research, learning and teaching that transforms the knowledge, action and leadership needed for more equitable and sustainable development globally.

Ayesha Khan and Asiya Jawed are based at the Collective for Social Science Research (CSSR). CSSR is a centre based in Karachi, Pakistan, which conducts both quantitative and qualitative studies in the areas of social policy, economics, poverty, gender studies, health, labour, migration, and conflict in the region.

Salvador Forquilha and Crescêncio Pereira are from the Institute for Social and Economic Studies (IESE). IESE is an independent research centre based in Maputo, whose main vocation is to undertake research and, through that, to produce knowledge and intellectual capacity to feed the public debate on questions related to economic, social, and political development of Mozambique.

Victoria Ibezim-Ohaeri and Zikora Ibeh work at Spaces for Change (S4C). S4C is a non-profit organisation that provides cutting-edge expertise in policy analysis, community engagement and research advocacy, focusing on four thematic areas: urban justice, energy reforms, gender inclusion and defending civic space.

\section{Acknowledgements}

This research would not have been possible without the committed and sustained participation of Observatory Panel members in Pakistan, Mozambique and Nigeria. We thank them warmly for their inputs. We also thank Naomi Hossain for insightful review comments.

Citation: Anderson, C., R. McGee, N.J. Nampoothiri and J. Gaventa, with S. Forquilha, Z. Ibeh, V. IbezimOhaeri, A. Jawed, A. Khan, C. Pereira and A. Shankland (2021) 'Navigating Civic Space in a Time of Covid: Synthesis Report', Brighton: Institute of Development Studies.

ISBN: 978-1-78118-800-2

DOI: $10.19088 / A 4 E A .2021 .002$

(C) Institute of Development Studies 2021

Institute of Development Studies

Library Road, Brighton, BN1 9RE, UK

www.ids.ac.uk

IDS is a charitable company limited by guarantee and registered in England

Charity Registration Number 306371

Charitable Company Number 877338

This is an Open Access report distributed under the terms of the Creative Commons Attribution 4.0 International licence (CC BY), which permits unrestricted use, distribution, and reproduction in any medium, provided the original authors and source are credited and any modifications or adaptations are indicated. http://creativecommons.org/licenses/by/4.0/legalcode 


\section{Contents}

$\begin{array}{ll}\text { 1. Introduction and background } & 10\end{array}$

$\begin{array}{ll}1.1 \text { Introduction } & 10\end{array}$

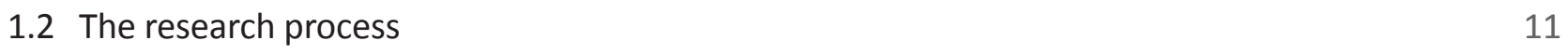

1.3 Civic space pre-pandemic: Civic energy amidst shrinking space for dissent 13

$\begin{array}{ll}1.4 & \text { The shock of the pandemic: Openings and closures } \\ \end{array}$

2. Mozambique, Nigeria, and Pakistan: Governance, civic space, and the unfolding of the pandemic 16

$\begin{array}{ll}2.1 \text { The governance contexts } & 17\end{array}$

$\begin{array}{ll}2.2 \text { Civic space before the pandemic } & 17\end{array}$

2.3 When the pandemic struck: Cases, policies, and narratives 19

2.4 A year of intersecting crises 22

$\begin{array}{ll}\text { 3. Civic space during the pandemic } & 23\end{array}$

3.1 Executive over-reach, securitisation and suppression of dissent 24

3.2 Freedom of press and of expression 26

3.3 Tightening online space 28

3.4 Social division, stigmatisation and polarisation $\quad 29$

$\begin{array}{ll}3.5 \text { Centralisation and sub-national divergence } & 30\end{array}$

$\begin{array}{ll}3.6 \text { Shifts in funding flows } & 31\end{array}$

4. Civic action during the pandemic; changes in salience in issues, actors and coalitions, and repertoires 32

4.1 Healthcare 33

4.2 Providing and monitoring Covid relief $\quad 35$

4.3 Education 36

$\begin{array}{ll}4.4 \text { Gender-based violence } & 37\end{array}$

4.5 Economic issues and livelihoods 38

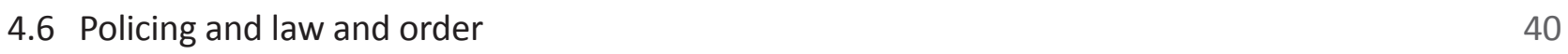

5. Implications: What does the 'new normal' mean for governance? 41

5.1 For civic space: 'No space to breathe' 42

5.2 For citizen-state relations: Prolonged post-pandemic polarisation 42

5.3 For civil society and civic action: Weathering, circumventing or countering the constraints 43

5.4 Conclusion 44 


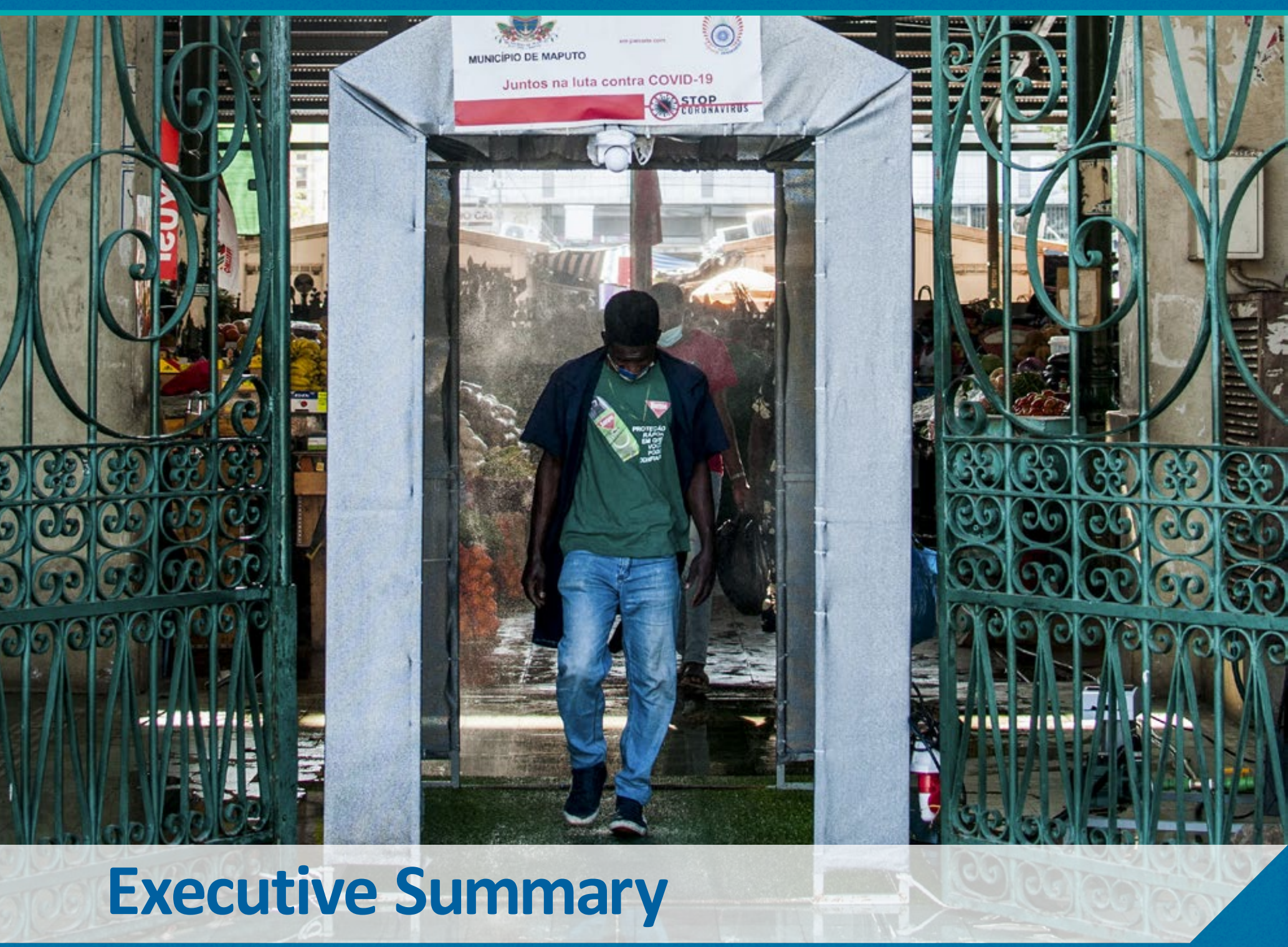

Since long before the Covid-19 pandemic emerged in 2020, civic space has been changing all over the globe, generally becoming more restricted and hazardous. The pandemic brought the suspension of many fundamental freedoms in the name of the public good, providing cover for a deepening of authoritarian tendencies but also spurring widespread civic activism on issues suddenly all the more important, ranging from emergency relief to economic impacts. The Navigating Civic Space in a Time of Covid project has explored these dynamics through real-time research embedded in civil society in Mozambique, Nigeria, and Pakistan, grounded in a close review of global trends.

Covid-19 disinfection tunnel at Mercado Municipal in Maputo, Mozambique, May 2020.

PHOTO:

SAM SHERRATT, VIA WIKIMEDIA COMMONS CC BY-SA 2.0 


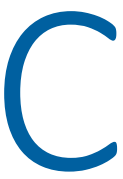

ivic space matters for a host of reasons. Our concern is how far it allows civil society actors freely and safely to advocate for rights, express dissent or opposition and contribute to public deliberation. In times of crisis, these freedoms acquire particular importance. The impacts of crisis usually fall disproportionately on marginalised people whose interests are least represented in formal democratic institutions, and need to be redressed through claim-making in the civic space.

Globally, the pre-pandemic year of 2019 has been described as the fourteenth consecutive year of decline in global freedom, with 'democracy and pluralism [...] under assault ${ }^{1}$. Yet even as the governance landscape has become more authoritarian and autocratic over the past two decades, instances of movement-based 'people power' have increased and diversified and online activism has burgeoned, even in settings of severely limited civic space.

From March 2020 the Covid-19 pandemic triggered a rash of policy and other measures that restricted civic freedoms in the name of public health, with striking similarities across the globe. The closing of civic space has taken a range of forms, overt and covert, from formal legislation and policy to highly targeted harassment, divide-and-rule and delegitimising tactics. The chilling effects of these tactics are often all the greater and more divisive because of their selective and arbitrary application. While both the autocratising trend and the resurgence of civic action were visible before, both seem to have accelerated and magnified since the onset of the virus.

This report presents the findings of a collaborative research study exploring these dynamics in Mozambique, Nigeria, and Pakistan, three countries whose hybrid regimes combine democratic institutions and processes with autocratic ruling practices and trends of narrowing civic space. Built around a monthly Observatory Panel methodology, continuous event cataloguing and key informant interviews from June - December 2020, this innovative real-time research captured the perspectives and experiences of civil society actors on changes in civic space and action, drawing on global literature and commentary to situate and interpret these. We sought to understand what the changes mean for the future of democratic governance in these countries and more broadly, and what strategies are needed to prevent and withstand further closure of civic space.

The amassed evidence and commentary show a surge in autocratic behaviour and decline in democratic freedoms during the pandemic.
An emergency heightens society's need to be governed. Protecting and restoring public health in a pandemic requires complex and restrictive regulation. Responding to crisis strains the social contract and tests states' and governments' systems for governing the collective and distributing public goods. But while measures were undoubtedly needed, the pandemic was used as cover for implementing emergency measures without time limits, silencing or eliminating critics, and curtailing the three freedoms most integral to civic space - freedom of peaceful assembly, freedom of expression and freedom of association.

Against this backdrop, commentators noted emergent forms of civic agency and mobilisation, and newly important issues, actors, repertoires, and opportunities. As often before under military or authoritarian rule, in this 'new normal' civil society organisations (CSOs) and activists are devising strategies to navigate the space available, minimise the risks they face, and grasp what opportunities they can.

\section{Mozambique, Nigeria, and Pakistan, far from being exceptions in an otherwise democratic world, illustrate both the pre-pandemic and in-pandemic trends set out above. The three countries also had some common characteristics in the 'old normal' before the pandemic, which they shared with many other countries as well.}

The democratic credentials of these three countries are neither the worst nor the best; they are hybrids, combining some elements of democracy, with others of more autocratic rule. They share post-colonial histories of repressive military rule; legacies of conflict and violence, continuing today in regions of each country; high levels of poverty and inequality; and low trust between citizens and government rooted in widespread perceptions of corruption.

Despite these challenging circumstances, each of the countries, to varying degrees, has a vibrant civil society and a history of informal protest and contention towards its ruling regime. However, true to autocratic regimes, this civic history does not reflect ample civic freedoms nor necessarily translate into greater voice and accountability. Pre-pandemic, each country was already seeing a tightening of civic space and activity, with growing pressure particularly against CSOs, media and activists directly critical of the status quo. A growth of restrictive legislation was tending to choke CSOs, online activism was under increasing surveillance and intervention, and the traditional media, although active, suffered frequent attack and sabotage in response to critical coverage. 
Less visible social and political pressures mobilised around religion, ethnicity, anti-Western sentiment or national security discourses conspired with this legislation to stifle dissent.

From early 2020, the spread and severity of the pandemic played out differently in Mozambique, Nigeria, and Pakistan. While official case and death rates were by far the most severe in Pakistan, similarly rapid and drastic policy responses were seen in all countries, accompanied by similar narratives and attitudes.

In each country the shock of the pandemic coincided with other major events, some of which overtook the virus in terms of public policy priority and even dwarfed it in terms of public perceptions. Key among these were the flood emergency in Pakistan, the pandemic-induced shock to Nigeria's oil-based public finances and in all countries flareups of violent conflict, never far away - Islamist insurgency in northern Mozambique, ethno-religious violence in northern Nigeria, and insurgency in Balochistan Province, Pakistan. These other shocks, some of them with profound economic and political ramifications, brought forth civic action of their own. The pandemic context both exacerbated the shocks' effects and shaped the ensuing civic action.

\section{What happened to civic space in Mozambique, Nigeria and Pakistan under the pandemic?}

\section{A key feature of the global commentary on governance and civic space during the pandemic has been the opportunity and impetus it gave states to consolidate and extend authoritarian and autocratic tendencies.}

Over and above the most obvious restrictions on freedom of assembly, human rights abuses and examples of state over-reach during the pandemic, more insidious and longer-standing assaults on civic freedoms continued. Moves to control the debate and silence critical voices applied as much online as offline. The pandemic exacerbated sources of division amongst civil society, and sometimes dissipated civic energy. Tensions and divisions also played out between different regions of each country, and between central and subnational authorities. The re-direction of public and international donor funds towards pandemic response provided important opportunities, but also threatened to be divisive.

In common with many countries around the world, the pandemic triggered emergency legis/ation and 'lockdown' restrictions on many facets of life in all three countries. This represented a significant shift towards executive authority, unleashing a concentration of power that undermined established processes for public deliberation and participation. Lockdowns offered new latitude for 'over-reach' by authorities, in particular police and security forces.

Alongside the attacks on human rights that flourished or ensued under cover of the pandemic, lockdown restrictions and the 'securitisation' response had the immediate effect of reducing the civic space available to challenge these tendencies. However, restrictions were not applied equally: different political parties, social classes, religions and livelihood groups experienced differential treatment. In all three countries the alreadyfamiliar tactic of forced disappearance continued, arguably made easier by stay-at-home orders, and particularly targeting journalists.

Even as the first wave of transmission waned, securitisation of the pandemic deepened, restrictive legislation was extended, and individual activists and dissenters were punished for protesting. In the background, longstanding legislative manoeuvres to tighten regulation of civil society continued unabated.

Press freedom was under pressure in all three countries, as the pandemic heightened the sensitivities of those in power while exposing them to critique.

Media outlets and journalists were singled out for targeted suppression or attack. States made use of both fake news and accusations of fake news in what became an information war. Over the year, as intimidation and fear gave rise to selfcensorship both on- and offline, general trust in even independent media outlets to reflect the situation on the ground fell away.

As civic action moved online, so did efforts to undermine and regulate it, and silence critical voices.

The public health measures of the pandemic closed down many 'offline' spaces for protest, hastening a move to online spaces. But repression rapidly caught up: legal regulations were used in both Pakistan and Nigeria to increase state control of digital tools and spaces and limit free expression, and online harassment and trolling targeted Pakistani women journalists critical of the government's Covid-19 narrative. 
Across the three countries, the response to the pandemic exacerbated existing social divisions, with discourse and action playing into tensions between communities, and the pandemic hitting harder those already excluded or vulnerable. A more fractious and antagonistic public debate raised the stakes for those acting in civic space, particularly those acting for the needs of stigmatised minorities.

In the early days of the pandemic, before cases were widespread and community transmission accepted, it was often framed as an 'imported' virus, and supposed 'carrier' population groups stigmatised. As transmission spread and the parallel actions of authorities to enforce lockdown measures and provide targeted relief ramped up, further tensions were inflamed, along pre-existing ethnic and religious fault-lines. Blasphemy accusations came to be used as weapons in deepening sectarian tensions particularly in Nigeria and Pakistan.

The need for decisive action in the face of the pandemic saw not only the shift of power towards the executive or military discussed above, but also a centralisation of authority and increasing tensions between national and sub-national authorities. This had consequences for the locally empowering and democratising effects - actual or potential - of each country's decentralisation trajectories to date.

State of Emergency legislation tended to centralise power and sow tensions or confusion around administrative and political decentralisation, with national and subnational authorities diverging in their approaches to the pandemic in some cases. Tensions also arose around distribution of pandemic relief and aid. Overlaid on the sub-national conflicts and ethnic and religious tensions already going on in all three countries, the combined effect was to make civic space far from uniform across the territories, with divides between rural and urban areas, capital cities and peripheries, conflictual and stable regions, governing-party-led and opposition-led areas.

The pandemic put significant financial pressure on governments and civic organisations alike. The need to re-direct resources to pandemic response had its own impacts on civic space. This included redirection of donor funds that previously supported a wider range of CSO activity and led to changes in the civic landscape in our three countries.

In our three contexts international funding of civic organisations, and larger CSOs, has been important historically in sustaining their role in civic space. The re-direction of these funds to Covid-19 relief had mixed effects: positively, a more adaptive attitude by donors towards local CSOs in Nigeria, and negatively, the favouring of less politically challenging, more welfare- and humanitarian-oriented organisations over advocacy and rights-focused organisations in Mozambique and Pakistan. Competition between CSOs was observed to increase, weakening the potential for collective voice and coordinated action.

\section{What happened to civic action?}

During the pandemic a host of public policy concerns became especially salient, and much civic energy and action shifted towards these. Action on these issues drew in and brought together new actors and new coalitions, sometimes expanding the repertoires of action they used to navigate the available space. This came about in part as the sectors and issues most affected by the pandemic acquired new urgency, but also in more subtle ways, as the pandemic laid bare the unfairness of the status quo.

Important shifts in civic action in Mozambique, Nigeria, and Pakistan since the onset of the pandemic have been both because of and in spite of the narrowing civic space. Whilst not without precedent in any of the countries, these shifts are clearly associated with the pandemic. The pandemic re-directed attention and civic energy towards certain issues that stood out in a global and national public health emergency. Drawn out by the changing salience of issues, new actors and new coalitions came to the fore, sometimes out of necessity and other times as a strategic response. With them came adjusted repertoires of action. The spread of digital protest sped up; citizen oversight mechanisms sprang up to monitor Covid-19 emergency relief, often empowered and emboldened by digital technologies; and unruly expressions of popular politics were common.

Unsurprisingly, the pandemic put public healthcare systems under the microscope, with health systems worldwide struggling to cope, and healthcare workers on the frontline of the fight against the pandemic. Correspondingly, these workers and their allies have mobilised across the world to demand more resources, greater protection in the form of PPE and risk payments, and greater recognition. Longerstanding grievances made common cause with pandemic-related mobilisations for better resourcing regulation and defence of public healthcare services. 
In these three countries as well as globally, CSOs set about repurposing themselves to do emergency relief work, as well as pressurising the state to provide relief and monitoring it when it did so. Taking on relief roles, sometimes even in partnership with governments, brought CSOs some room for manoeuvre in increasingly hostile environments. Attempts to hold government accountable for the management of significant Covid-19 relief funds raised domestically and from donors overseas - were witnessed in Mozambique and Nigeria. Coalitions proved crucial for both delivering relief and holding government accountable.

Education was one of the key sites of disruption and contention during Covid-19, against a background of widespread challenges in schools and university access and quality. Issues such as school and university closure and inequalities in remote learning brought forth demands for accountability from civic actors and the general public. Simultaneously students and teachers played a significant role in popular protests during this period. Concerns about student safety and possible transmission of the virus were highlighted by groups in all three countries, with a common theme being the public debate over reopening of schools.

Emergencies and crises are known to increase gender-based violence (GBV). Evidence confirms this for the Covid-19 pandemic globally. Responses and mobilisation from both organised and unorganised civil society emerged on these issues across all three countries in this project. The rise in GBV was met with petitions, physical protests, advocacy, digital activism, direct service provision and coordination with the state and other civil society actors. This civic action generated discussion and public condemnation of GBV both online and offline, and some significant moves to improve legal frameworks surrounding GBV and harassment in Nigeria and Pakistan.

The economic impact of the pandemic was significant in all three countries. Immediate restrictions on businesses and trading were followed as the pandemic wore on with escalating concerns about livelihoods, unemployment and the costs of basic goods, all of which triggered new action and demands from civic organisations. Those reliant on the informal economy were particularly vulnerable, and the inability of social security and social protection systems to cushion the economic fall-out was laid bare in many countries. Consequently, the pandemic provoked several prominent instances of civic action led by unions, professional associations and unique coalitions that sought to address issues concerning the economy and livelihoods.

The heavy-handed and securitised response to the pandemic brought to crisis point a range of longheld grievances about the insecurity facing people in their everyday lives, and the role of state actors in sustaining or causing that insecurity ${ }^{2}$. Around the world this manifested in a range of action, including protests against lockdown and public health measures. In all three of our countries, it created grounds for flashpoints in relation to law and order and the actions of security services of which the \#EndSARS campaign to abolish Nigeria's particularly brutal Special AntiRobbery Squad (SARS) was the most emblematic.

\section{So what does the 'new normal' mean for governance in the longer term?}

\begin{abstract}
A further narrowing of the democratic arena where contestations, differences and inequalities can be managed without recourse to violence has happened simultaneously with the undermining of the actors who play key roles in speaking out and staking claims democratically. The patterns and trends we have observed and our interpretations of them - grounded in active current engagement in Mozambican, Nigerian and Pakistani civil society - point to three sets of implications: for civic space; for citizen-state relations; and for civil society and civic activism.
\end{abstract}

In these contexts of fragile political pluralism, civic space at national and sub-national levels has been a crucial arena for critical dialogue, expression of difference and honing of oppositional stances. Yet the governments of Mozambique, Nigeria, and Pakistan have each been particularly swift and far-reaching in rolling back democratic progress under Covid by squeezing an alreadyconstrained civic space still further. Here and in a wide range of other countries, power seems likely to become more centralised and less shared, and civic space more constricted, unless there is a concerted global effort to protect it.

What we have seen in 2020-21 might be just the beginning of an enduring securitisation of public health and democratic governance, in 
which citizen-state relations are re-framed more antagonistically as one protects a securitised version of public health and civil liberties. As trust declines further and polarisation increases, elements within both 'sides' are likely to drive the other towards extremes. International aid actors seeking to support civil society have long needed to resist treating it as monolithic or uniform, but official and non-governmental donors to these three countries and the many other aidrecipient countries undergoing similar trends will likely need to make harder choices about which civil society actors to align themselves with. To continue providing effective support to civic space and action, official bilateral aid will need to become more politically informed and work more closely with diplomatic and multilateral channels.

Despite the evidence of newfound coalitions and solidarity especially early in the pandemic, the fissures, fragmentation and competitive dynamics showing up in civil society in all three countries look likely to increase. Civil society may well segment into actors that weather civil-society-restricting moves, those that circumvent them, and those that actively counter them. Mozambique, Nigeria, and Pakistan may see the emergence of small but stronger and more significant contentious segments of civil society than have existed before, even while other CSOs retreat from advocacy into uncontroversial service provision roles. Even in its evermore strategic use of online spaces and digital communications civil society will be hard-pressed to stay a jump ahead of state security forces' interference as regulation and technology in these spaces evolve.

More positively, spurred by new levels of outrage around issues of equitable distribution, transparency and accountability thrown into relief by the Covid-19 pandemic, civic action has found fresh impetus. At least some of the coalitions forged in the heat of the pandemic are likely to endure as a safer and surer way of operating, perhaps maturing into deeper, cross-class alliances as the longer-lasting effects of the pandemic and policy and budget responses to it are felt on livelihoods and lifestyles. No less will be needed to hold open a further-shrinking civic space.

The shifts in citizen-state relations we have seen intensify during the pandemic call for re-strategising, re-positioning and re-tooling by advocates of democracy and accountable governance at all levels. Activists and civic organisations will have

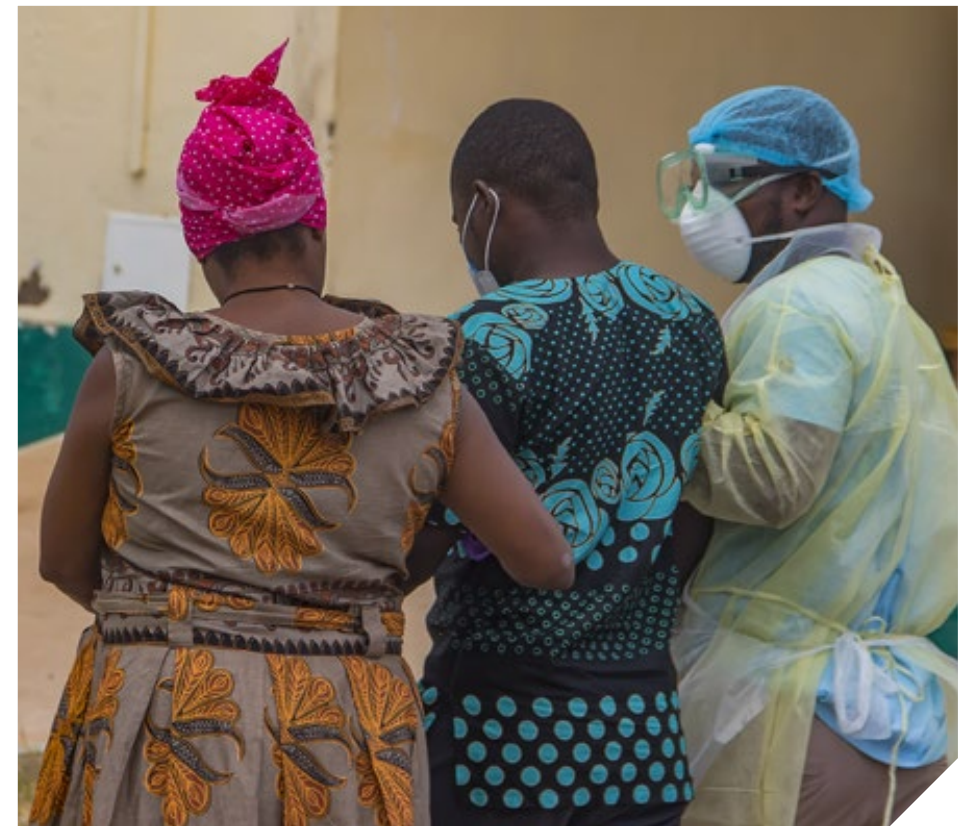

difficult choices to make, and need to chart a ABOVE careful path to maintain solidarity across causes and identities. International actors, including aid donors, need to revive approaches used in the least democratic settings and in less democratic global eras. In contexts where civil society, civic space and government notions of accountability have been heavily shaped by international aid, the defence of civic space and assertion of Covid-19 positive patient, taken to hospital by medical staff, Mozambique, Beira city, June 2020.

РНОTO:

MIROS LAV, SHUTTERSTOCK.COM accountability claims over the past year by domestic social actors - not dominated by donors or international NGOs - hold particular promise. The energy generated to monitor civic freedoms and call out the democratic backsliding we have seen during the pandemic must be sustained, and both national and international attention focused on the dangers of emergence from the pandemic with our civil liberties eroded and autocratic governance normalised. 


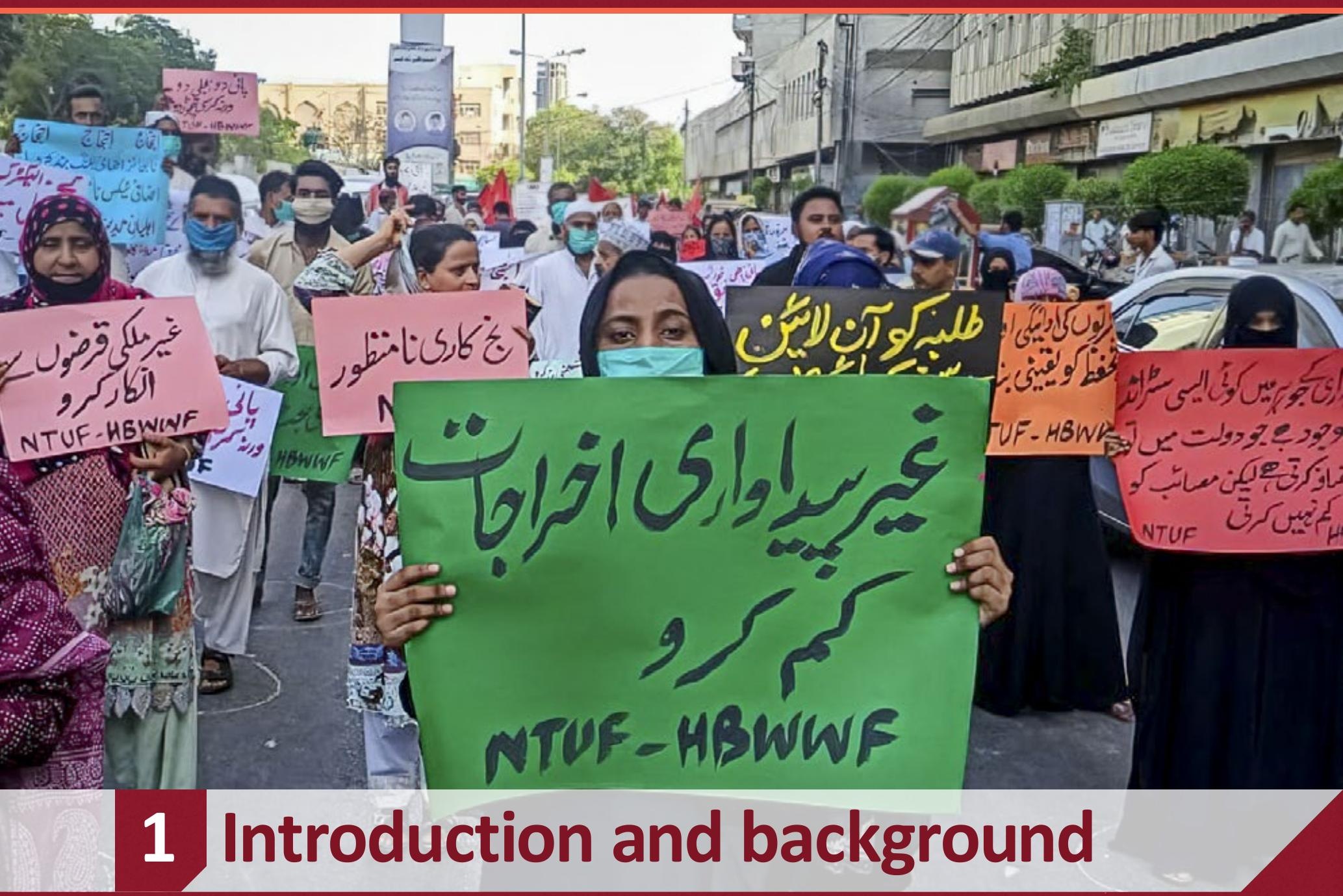

The crisis of Covid-19 arrived against a backdrop of declining civic freedoms in both newer and more established democracies, but also a widely observed and simultaneous resurgence of popular protest and people power. The emergency heightened the need for governance. But the measures adopted and the way that authorities applied them were quickly and frequently seen as suppressing dissent and targeting opposition voices, spurring an active global conversation about the long-run implications for civic freedoms and action, and democratic values and norms. This is a contribution to those debates. We report from six months of research in Mozambique, Nigeria, and Pakistan during 2020. Observatory panels of civil society leaders in each country monitored and made sense of events in real-time, alongside extensive event cataloguing and inputs from the live global debates.

Members of the National Trade Union Federation and Home-based Women Workers Federation take part in a sociallydistanced protest about economic pressures in Karachi, Pakistan, November 2020. PHOTO: KHIZER HABIB 


\subsection{Introduction}

Civic freedoms are in decline globally. Over many years pro-rights and accountability activists and campaigners in established and newer democracies alike have been operating in a space that is changing, in patterned ways. The crisis of the Covid-19 pandemic heightened attention to these patterns, as countries across the globe acted quickly and severely to restrict fundamental freedoms in the name of public health. As debates continue about 'building back better' in the wake of the pandemic, the reality is that many restrictions thought temporary one year ago are still in place. We face a world where the new language of lockdown heralds an acceptance, at least on some level, that fundamental freedoms can be suspended in the name of the public good. Not only are many restrictions still in place, but the evidence is increasingly clear that the cover of the pandemic has allowed governments to hasten their turn towards authoritarianism and autocratisation, changing the landscape in potentially permanent ways.

Simultaneously, we also witness a resurgence in people power and civic mobilisation both to claim rights and to call the system to account for injustices and lack of attention to issues of global urgency. Tightening civic space has not prevented the growth of mass movements, online campaigns, and popular protest. Anti-government protests are taking place on a significant scale in very different countries, and new digital tools and spaces afford new opportunities for action and connection. This civic energy was also an important part of the story of the pandemic - with self-help and mutual aid groups springing up, governments called out on their pandemic response, and issues of care, education, and social protection becoming a focus of active public debate.

These two trends - of increasing autocratisation, but also new expressions of 'people power' and civic dynamism - are clearly not new. But during a year of pandemic-induced crisis they have accelerated and magnified. This report looks at how these dynamics played out in Mozambique, Nigeria, and Pakistan three countries where the space for civic dissent and claims for accountability and better governance was already constricted, and practices of autocratic rule have sat alongside democratic processes and institutions for some time. Rather than being exceptional, these conditions of 'hybrid' governance are in fact common globally, as are their histories of colonial rule, internal conflict and division, and popular struggle for democracy.

The story we tell here comes from six months of collaborative research by institutes and civil society actors in each of the three countries, convened by a research team at the Institute of Development Studies under the
Action for Empowerment and Accountability research programme (A4EA). A4EA is a five-year programme that looks at how social and political action contributes to empowerment and accountability in contexts affected by fragility, conflict and violence ${ }^{a}$. Between June and December 2020, the research team undertook a monthly research cycle designed to capture events and changes in civic space and civic action in real time, and to understand these from the perspectives of those grappling with them. This report brings together key themes and findings from that process. Separate reports for each country are published by the research partners in the project ${ }^{3}$.

After more than a year of a global pandemic, space for organised citizens to engage with authorities on public policy choices, to examine the decisions being made, and critique and offer alternatives is more necessary than ever. But changes in the space available, the relationships between civic actors and governments that shape the space, and the kinds of issues that have salience raise crucial questions for the future. What genies has the pandemic let out of the lamp? What does that mean for our democratic futures in the coming years? What strategies do civic actors and those that support them need to take now to prevent further closures?

We turn to these longer-term questions in the final section of our report. The next part of this first section outlines the approach we took to researching these issues in real time from the perspectives of those grappling with them. We then look at the status of civic space, freedoms and action globally before the pandemic and during the past year. Section 2 turns to the countries, exploring the pre-pandemic context for civic action in all three and their similarities, and the different ways in which the pandemic played out in these contexts. Section 4 delves deeper into various ways that civic space has changed over the course of the year. Section 5 turns the lens on the civic action that arose or persisted as the space was changing - for the most part, closing.

The report is our evidence-based contribution to a multitudinous global conversation about how civil society organisations (CSOs) and active citizens can best strategise, act and navigate the turbulent dynamics we and many others are observing. Our data, generated from the ground up over this intensive six-month process spanning the first peak of the global pandemic, adds to the existing debates illustration, granularity and corroboration of a global phenomenon with farreaching, troubling consequences for democracy. It is addressed to advocates of democracy in both scholarly and activist roles who have focused on what is happening to civil society over recent decades, and to aid donors - official, philanthropy and non-governmental - who support democratisation and civil society, in the hopes of informing our collective strategies and actions. 


\subsection{The research process}

Navigating Civic Space in a Time of Covid-19 was a research project created under the Action for Empowerment and Accountability (A4EA) research programme in early 2020 , working with research teams in three of the A4EA focus countries: Mozambique, Nigeria, and Pakistan. The project design was methodologically innovative, based on a monthly research cycle intended to capture events and changes in civic space and civic action in real time and to understand these from the perspectives of civil society actors. Observatory panels of civil society leaders were established and met monthly in each country from June - December 2020, after the first waves of cases and lockdown measures, and through to the start, in most cases, of a second wave of infections. Effectively, these functioned as three recurrent focus groups, amassing qualitative panel data in fastchanging, and at times risky contexts. Together panel members reflected on the situation on the ground for the work they were trying to do, and commented on broader events, debates, and incidents. Relevant events were systematically catalogued by lead researchers based on a continual scan of traditional and social media. These 'event catalogues' provided content for debate in panel discussions, and provided a rich evidence base for a wide set of actions and patterns ${ }^{b}$. Panels had up to 10 members, representing different geographies and sectors. The members remained consistent throughout the project, allowing them to build relationships and continue a conversation together as the pandemic and policy responses played out. In some cases, panel members decided to continue collaborative analysis and advocacy work after the project finished. The panels met virtually using videoconferencing platforms, which meant that they could take place even during lockdown periods.

As a research team we mirrored this process at a crosscountry level: meeting monthly to digest and collectively analyse the discussions in each country observatory panel, finding commonalities and differences, and placing these against a monthly update on events in other countries or commentary from other studies. These layered discussions surfaced leads and insights that we fed back to the country observatory panels as themes for further discussion, and to be explored further in key informant interviews or 'guest appearances' of key figures holding dialogues with observatory panel members. Key informants were carefully selected to provide harder-to-reach perspectives, help ground-truth the other data, or fill in important gaps. Findings were compiled in reports for each country, complementing baseline studies completed by each country research team at the start of the project.

In a research process characterised by solidarity and mutuality, this approach privileged the voices of activists and organisers on the frontlines, valued their expertise and allowed us to bring together findings grounded in their particular priorities, surface cross-country patterns as they emerged, and place these in the context of a wider set of patterns from the global commentary on these issues.

\section{Figure 1. Our research process}

- Baseline studies: Understanding the recent trends in each country

- Event tracking: Media and social media scanning to identify relevant events and debates, fed into observatory panels

- Observatory panels: Around 10 civil society leaders in each country debating key themes and issues of the day each month

- Key informant interviews: Targeted interviews with civil society members and activists

- Global scanning: Summaries of new research and commentary on the pandemic, governance, and civic space, fed into monthly synthesis discussions

- Cross-country synthesis: Monthly dialogue on discussions in observatory panels, and patterns of events, informing new lines of enquiry

Country baseline studies

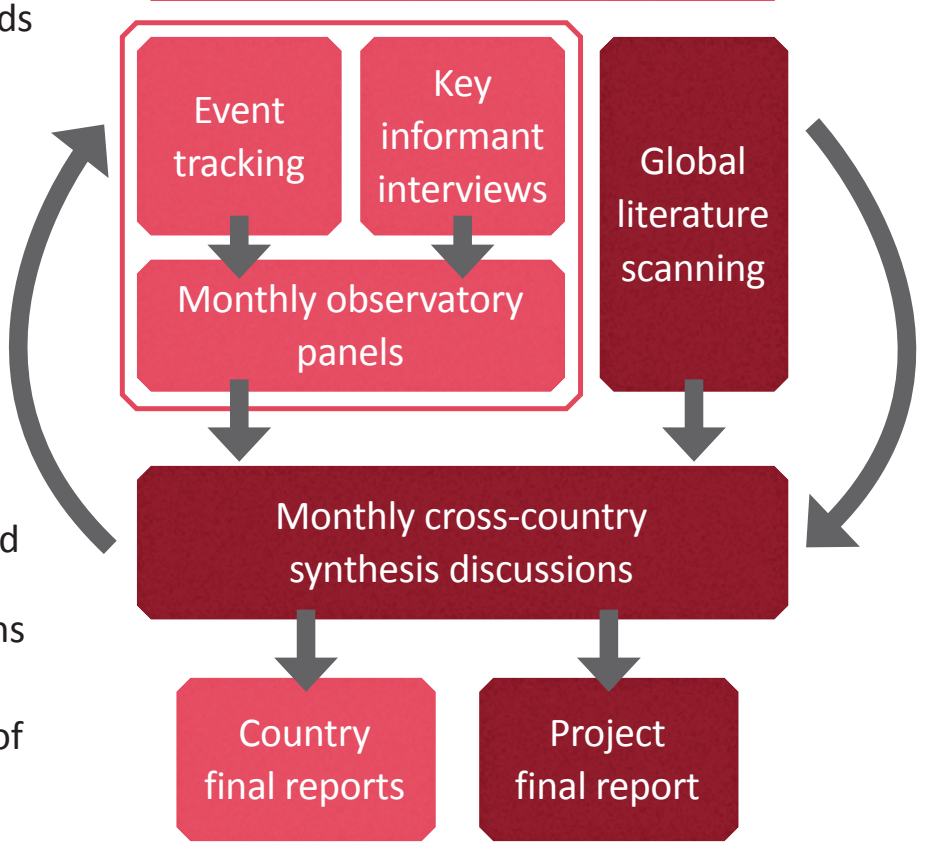

${ }^{\mathrm{b}}$ The event catalogue in Nigeria ran alongside the ongoing documentation maintained in the Closing Spaces Database by our Nigeria research partner, Spaces for Change. 


\subsection{Civic space pre-pandemic: Civic energy amidst shrinking space for dissent}

Commentators have been observing significant changes in civic space in countries around the world for several years now. Rising authoritarianism and autocratic ways of governing have put many civil society actors under significant pressure and eroded fundamental rights of association, assembly, and expression. Prior to the Covid-19 pandemic CIVICUS reported that 67 per cent of the world's population lived in countries where civic space was closed or repressed ${ }^{4}$. Freedom House declared that 2019 was the fourteenth consecutive year of decline in global freedom and that 'democracy and pluralism are under assault's. The 2021 V-Dem Democracy Report, entitled 'Autocratization Turns Viral', further documents these trends. According to this report, 68 per cent of the global population now live in autocracies, of which 'electoral autocracies' are most common ${ }^{6}$. These are regimes which fall short of democratic standards because of institutional weaknesses or limits on political competition, although they hold multiparty elections ${ }^{7}$. Hybrid regimes of this kind, where elements of democratic and undemocratic rule sit side by side ${ }^{8}$, are the reality for most people in the world.

In this paper we understand civic space broadly as the physical, virtual and legal place where people associate, express themselves and assemble. Civil society of course includes conservative, socially regressive and pro-government elements, as well as progressive critics of government. But we are specifically interested in how far the space available allows civil society actors to advocate for rights, express dissent or opposition, and contribute to public deliberation without, as Hossain and Khurana put it, 'fear of incurring official disapproval, hostility, violence or abuse, or without breaking laws or regulations ${ }^{\prime 9}$.

Sustaining more open civic space is fundamental to equitable and democratic dialogue, embracing pluralism and inclusion of the historically marginalised, and allowing people to realise fundamental rights to associate and speak freely. A United Nations Guidance Note from September 2020 pointedly notes that these freedoms and rights are especially important in times of crisis, and that when they are impaired this is often an early warning sign of further human rights
It is in times of crisis that civic space, transparency and the free flow of information

are more critical than ever for building and maintaining the trust needed for effective responses.

- UN Guidance Note on Civic Space, September 2020

violations. ${ }^{10}$ In addition, Hossain and colleagues make the developmental case that open civic space and the plurality it brings are central to the Sustainable Development Goals, arguing that progress on reducing inequalities is impaired when civil society groups can no longer empower and protect the poor and marginalised. ${ }^{11}$

There is a substantial literature evidencing a wave of actions that have closed civic space across diverse contexts in the past decades. ${ }^{12}$ Box 1 sets out the numerous forms they have taken. These actions are very often targeted at particular civic actors or organisations. Whilst some measures, like rules for CSO registration, might appear to apply to everyone, the space that different organisations and actors have available is far from uniform, and such rules are often applied arbitrarily. Based on country case studies, Hossain et al. argue that rather than an all-out closure in civic space what has been observed are selective and strategic changes that close down opportunities for those critical of governments and elites, including business elites. ${ }^{13}$ This finding chimes with those of Borgh and Terwindt, who show that the space available depends in part on the activities that CSOs pursue - with 'service-oriented' organisations having considerably more space under regimes that allow advocacy and rights-based organisations to be persecuted and closed down. ${ }^{14}$ Buyse notes the important role here of discourse that delegitimises 'political' actions by CSOs, advancing a narrative that sees civic organisations as primarily service providers. ${ }^{15}$

At the same time as these attacks, and often in the same places, many have noted a surge in civic energy and 'people power'. Maerz et al. argue that pro-democracy mass mobilisation was at an all-time high in 2019, and 'contributed to substantial democratization in 22 countries over the last ten years'. ${ }^{16}$ Others reflected too on 2019 as 'the year of protest', noting mobilisations around economic 
NAVIGATING CIVIC SPACE IN A TIME OF COVID: SYNTHESIS REPORT

crises as well as political leadership. ${ }^{17}$ Brannen et al. consider us in 'an age of global mass protests that are historically unprecedented in frequency, scope, and size'. ${ }^{18}$ Chenoweth contrasts the rise in nonviolent resistance with the decline in violent or armed campaigns since the 1970s, but also argues that in recent years - despite some clear wins by popular movements in a number of countries non-violent resistance has become less effective, partly as states have adapted their strategies to nullify or appease protests. ${ }^{19}$ Youngs argues that not only have the frequency and intensity of citizen campaigns and mobilisation increased since the turn of the 21st century, but that these have taken on new characters, strategies and tactics. ${ }^{20}$ He identifies a rise in movement-style politics and direct-action that corresponds with others' views of resurging popular mobilisation and protest, with rapid growth of online space providing new avenues for solidarity and transnational connections.

Whilst public protest and mass mobilisation depend on a degree of civic space, the hybrid political systems in much of the world mean that this surge of civic energy is not limited at all to more open or democratic places. The Carnegie Endowment for International Peace Protest Tracker finds that anti-government protests of significant scale happened in 78 per cent of 'authoritarian or authoritarian-leaning' countries since $2017 .{ }^{21}$ Nor do decades of increasing pressure on CSOs mean that they are out of the picture in these contexts. Instead, as often before under military or authoritarian rule, CSOs and activists adopt strategies to navigate the space available, minimise the risks they face, and take what opportunities they can. They might actively counter restrictions, for example mobilising people and international organisations or foreign governments in support. They might find ways to circumvent new restrictions to continue their activities. Or they may choose to weather the attacks in the hope of greater openness down the line. A review by the Norwegian development agency NORAD in 2018 distinguished between pro-active responses that sought to (re)claim spaces to operate and legitimacy, and reactive responses. Reactive responses they observed included self-censorship, shifting work towards service delivery, working in relatively more open sub-national areas, and challenging de-legitimising discourses. ${ }^{22}$ El Assal and Marzouk trace similar strategies of human rights organisation in Egypt in the crackdown that followed the Arab Spring, but also choices to relocate organisations outside of the country, cut ties with foreign donors and re-orientate to 'membership models' to secure funds. ${ }^{23}$

\section{Attacks on civic space take various forms and include ${ }^{24}$ :}

- Formal and legal restrictions and regulations on organisations, including the legal right of civic organisations to exist, curtailments on their income and activities, and supervision by the state

Restrictions in freedom of speech and press freedom

Restrictions in access to information and communication, notably through regulation and policing of digital and online space
- Targeting of activists and activist civil society organisations for individual harassment, persecution or violence, including malicious prosecution and selective assassination

- Tactics that divide and fragment civil society groups and campaigners

- Co-optation of CSOs by state or other actors, reducing their independence

- Anti-CSO discourses, negative labelling, and stigmatisation 


\subsection{The shock of the pandemic: Openings and closures}

An emergency heightens society's need to be governed. Protecting and restoring public health in a pandemic requires complex and restrictive regulation. Responding to crisis strains the social contract and tests states' and governments' systems for governing the collective and public goods. Covid-19 triggered a rash of policy measures that restricted civic freedoms in the name of public health, with similar policy responses spreading quickly across countries with diverse needs and exposure to the virus.

These policy measures and the actions of authorities were fast brought into focus by watchers of civic space and democratic standards, with numerous projects mobilising or pivoting to monitor newly restrictive changes in laws and governance practices worldwide $^{c}$. The evidence and commentary that resulted shows a surge in autocratic behaviour and decline in democratic freedoms. ${ }^{25}$ Whilst public health measures were undoubtedly needed, the threat of a global pandemic was used to implement emergency measures without time limits, curtail democratic freedoms and put critics behind bars in many countries. ${ }^{26}$ Many have argued that governments used the public health crisis to become increasingly authoritarian. ${ }^{27} \mathrm{~V}$-DEM, which launched a project on 'pandemic backsliding' on democracy and tracked violations of democratic norms across the year, observed that 55 autocratic regimes engaged in major or moderate violations of international norms ${ }^{28}$.

The pandemic response resulted in a global decline in the three freedoms that are integral to civic space - freedom of peaceful assembly, freedom of expression, and freedom of association. Freedom of peaceful assembly was the most affected due to the nature of the virus which required people to maintain social distance, and the widespread use of stay-at-home or lockdown orders ${ }^{29}$. Information and its accuracy took on new currency and became more contested in the face of an unknown virus and its rapid spread, leading to many measures curtailing freedom of expression. This 'infodemic'30 provided ample space for governments to pass new laws concerning fake news which in practice were used to curb dissent ${ }^{31}$, and use other laws, for example on sedition, to silence critics of pandemic responses ${ }^{32}$. Freedom of association was undermined through increased regulation of CSOs, particularly in relation to foreign funding, during the pandemic ${ }^{33}$. Online space acquired increasing relevance during the pandemic given the restrictions on physical assembly, building on the pre-pandemic trends noted above ${ }^{34}$. Activists used digital media to organise themselves, spread information, show solidarity and share resources in new ways. However as civic actors increasingly relied on online spaces, governments began closing these spaces $^{35}$. Various governments used contact tracing apps to increase surveillance, social media groups to censor narratives, and internet shutdowns to limit communication ${ }^{36}$. Section 3 illustrates how these trends played out in Mozambique, Nigeria, and Pakistan.

At the same time, we also see emerging forms of agency and civic action in response to the crisis, and newly important issues, actors, and repertoires. The areas of policy and of life that gained prominence as focuses of activism were those that were most acutely affected either by the pandemic itself or by policy responses to it. Mutual aid groups, community-based organisations, and informal networks came to the for $\mathrm{e}^{37}$. Emergent repertoires included use of digital spaces, online-offline protests, people-less protests and new coalitions ${ }^{38}$. New opportunities presented themselves for civic actors to work on issues of service delivery, spreading accurate information working in new coalitions, including with government actors. All of these developments provided signs of how civic groups' navigation of the pandemic might enable them to continue surviving in the context of closing civic space, a subject we return to in Section 4.

\footnotetext{
'See for example the V-Dem monitor of 'Pandemic Backsliding', the International Press Institute Covid-19 Press Freedom tracker, the International Centre for Non-profit Law COVID-19 Civic Freedom Tracker, and the Iransparency and Accountability Initiative's 'tracker of Covid trackers'.
} 


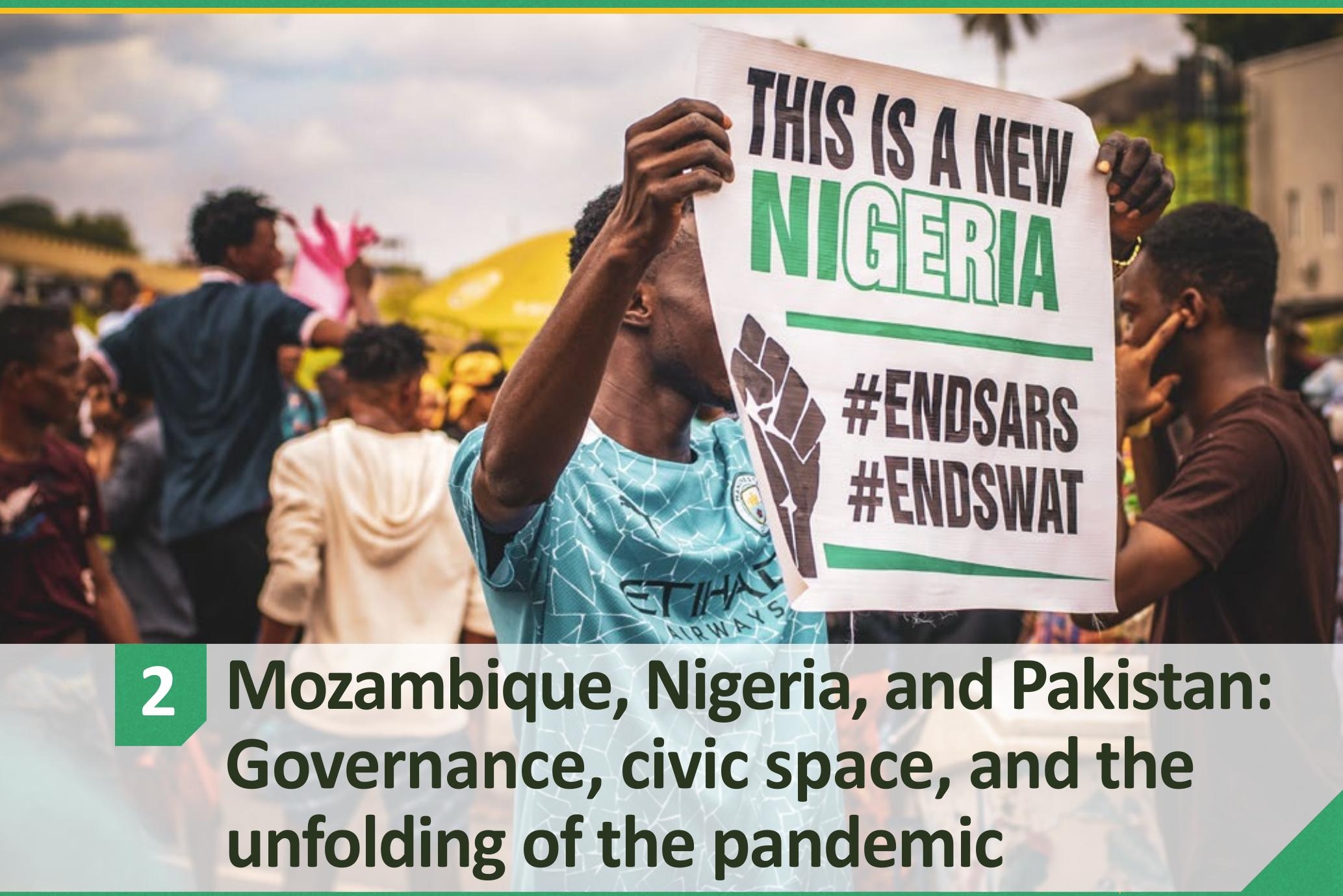

Mozambique, Nigeria, and Pakistan offer prime examples of the global trend that has been seen over the last decade towards increased authoritarianism and closing of civic space. The three countries also share histories of postcolonial military and single-party rule, legacies of violence and continued internal conflicts and security threats, a high degree of poverty and other human development needs, and weak forms of voice and accountability. Despite these challenges, each country also has a history of civic activism, which grew following the creation of spaces for democratisation in their respective constitutions. In more recent years, however these spaces have come under renewed pressure with both formal and informal attacks. The pandemic played out differently in each. While official case and death rates were by far the most severe in Pakistan, similarly rapid and drastic policy responses were seen in all countries, accompanied by similar narratives and attitudes. In each country the shock of the pandemic coincided with other major events, including natural disasters, economic crises, and resurgences of violence and sub-national conflict. The pandemic context both exacerbated the shocks' effects and shaped the ensuing civic action. 


\subsection{The governance contexts}

Mozambique, Nigeria, and Pakistan illustrate the global trends highlighted above. Rather than exceptions to an otherwise democratic world they reflect situations that are more common than not. While they do not represent the most 'closed' or autocratic settings, neither are they the most open. All three were classified by the V-Dem Global Democracy Report as 'electoral autocracies' in $2019^{39}$, and as 'hybrid' regimes by the EIU Democracy Index ${ }^{40}$. According to the Civicus Monitor on Civic Space, all three countries had 'repressed' or 'obstructed' civic space prior to the pandemic ${ }^{41}$.

The countries share other characteristics in addition to these broad indicators of democracy, which have long affected the nature of citizen-state relations ${ }^{42}$. Perhaps the most important of these is that they share histories of military rule, and memories of the repressive power of the military remain strong. Following independence from their colonial powers, both Nigeria and Pakistan have experienced intermittent military governments, up until 1999 in the case of Nigeria, and as late as 2007 in the case of Pakistan. In Mozambique, the dominant party, Frelimo, has been in power since 1975, and with that power has come the consolidation of control over the security apparatus.

Closely aligned to the history of military power, and dominant-party control of the security apparatus, these countries also share legacies of conflict and violence involving resource-rich but historically marginalised regions. Following independence, Mozambique experienced civil war up until 1992. Currently, security concerns continue with the increased violence linked to a jihadi insurgency in the northern Cabo Delgado region, as well as a renewal of conflict with a breakaway military branch of Renamo, the main opposition party, in Manica and Sofala provinces. Nigeria similarly faces the rise of the Islamist Boko Haram in the north, as well as ongoing conflicts amongst religious and ethnic groups, longstanding unrest over oil extraction in the Delta and a resurgence of pro-Biafra groups following its own civil war over fifty years ago. Pakistan faces conflicts related to Taliban insurgency in Khyber Pakhtoonkhwa (KP) and nationalist insurgency in Balochistan provinces. All three countries are regarded as 'highly fragile' in terms of security and either 'severe' or 'high' in terms of societal fragility ${ }^{43}$. Yet they are not fragile states in terms of their repressive power. As we shall see, in such settings 'national security' or 'anti-terrorism' can be invoked to suppress dissent and close civic space, and with the historically central roles of the military and secret police in these countries, these threats cannot be taken lightly.

It is also important to note that these are low income and highly unequal countries, where livelihoods and access to basic services such as health and education remain a daily struggle for vast numbers. Each of these countries sit at the extremely low end of the Human Development

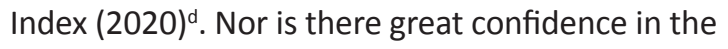
government's abilities to deliver on these needs for basic services, as these countries also rank relatively high in terms of perceived corruption, with high levels of mistrust of the state ${ }^{44}$. Even before the pandemic crisis, there were huge unmet needs and vulnerabilities within the population - which would continue to worsen when the pandemic began.

\subsection{Civic space before the pandemic}

Despite the challenging settings described above, each of these countries has a vibrant civil society and, to varying degrees, a history of informal protest and contention towards the regime. Pakistan, for instance, has over 45,000 registered non-profit organisations, and while the government favours those that focus on service delivery or humanitarian relief, many organisations have historically managed to work on more contentious issues of gender justice, human rights, and democratic politics. At key moments in history, mobilisations and protests have protected civic space or challenged government actions. Nigeria, similarly, has a large number and range of organised NGOs, as well as dense networks of more informal community-based organisations, faith-based groups, professional associations, trade unions, and others. Over 90,000 registered non-profit entities form a very important part of Nigeria's civil society sector, with their activities reaching millions of people ${ }^{45}$. Here, too, civic action is common, and the last decade has seen protest activity on the rise, with over 600 public protests recorded in 2019, an over 600 per cent increase from $2010^{46}$. In Mozambique, with its strong single party rule, civic space has historically been curtailed, and often dominated by party-affiliated mass membership organisations. In general, civic organisations here are more donor-driven, less established and less

\footnotetext{
${ }^{\mathrm{d}}$ In the Human Development Index, which is a composite index of health, education, standard of living and other factors, Mozambique ranked 181st out of 189 countries globally, Nigeria 161st, and Pakistan 154th in 2019.
} 
NAVIGATING CIVIC SPACE IN A TIME OF COVID: SYNTHESIS REPORT

MOZAMBIQUE, NIGERIA, AND PAKISTAN: GOVERNANCE, CIVIC SPACE, AND THE UNFOLDING OF THE PANDEMIC

autonomous from government than in the other two countries. Yet even here, since the 1990s CSOs have grown in number and type, and taken space to work on issues of rights and good governance.

Of course, in more autocratic regimes, this civic history does not necessarily translate into greater voice and accountability. Even before the pandemic, each of these countries was already seeing a tightening of civic space and activity, with growing pressure particularly against CSOs, media, or activists who challenged government or worked on governancerelated issues directly. The three countries rank low (Mozambique and Nigeria) or very low (Pakistan) and are on a downwards trend in the World Governance Indicators for Voice and Accountability ${ }^{47}$.

Many mechanisms contributed to this constricting of space, both formal and informal. Our baseline reviews of civic space before the pandemic pointed to the significance of legislative restrictions on CSOs, and tightening of online space (see Boxes 2 and 3), where legislation and regulation has actively reduced civic space or provided the tools to pursue critics. They also pointed to increasing pressure on press freedom, whether formally or through attacks and silencing tactics (see Box 4). Restrictions such as these interact with other more informal social and political pressures to silence or threaten dissenting voices. In both Nigeria and Pakistan, with deep religious divisions and growing fundamentalist movements, anti-blasphemy laws have been used to attack religious minorities or human rights activists. Groups may be stigmatised or attacked as antiIslam, pro-Western, terrorist, or threats to national security as pretexts to silence them. And in contexts with such histories of violence and repression, such threats may get put into practice through forced disappearances or abductions of journalists or activists. Examples of these actions, arbitrary arrests, and malicious prosecution of government critics exist in all three countries. In Pakistan official statistics recorded over two thousand pending cases of forced disappearances at the end of $2019^{48}$.

In each of these contexts, pressures or funding from international donors have historically been important for keeping democratic space open, or for supporting the work of human rights or prodemocracy groups. For example, in Pakistan other A4EA research ${ }^{49}$ has established how important international support for feminist activism and campaigning has been. However, increasing controls over financial flows, as well as anti-Western sentiments, have arguably limited the supportive role that even outside donors could play.

Box 2

\section{Restrictive legislation}

Although all three countries have constitutions that provide for civic freedoms, they have also, like so many around the world, seen the growth of regulations and rules which pose new hurdles for CSOs to register, receive funding and carry out their activities.

In Nigeria these include the NGO Regulatory Bill 2016 and Civil Society Regulatory Commission Bill 2020, various state level bills regulating NGOs, and other restrictions on financial flows, such as the National Risk Assessment Bill 2016.

In Pakistan, such moves have included the registration of all foreign-funded NGOs since 2015, registration of domestic NGOs with the Economic Affairs Division of government, and new Charity Commissions at provincial level that started to be established in 2018, as well as the use of 'No Objection Certificates' to gain approval for individual activities.
Restrictive legislation has been on the books in Mozambique for several years, although had not passed into law by the time of the outbreak of the pandemic. A new press law, however, has been widely criticised for restricting the freedom of operation of non-state media, reversing the tendency of previous decades when much progressive legislation (including on freedom of information) had been passed.

While such legislation in and of itself may not be restrictive, it has been seen to be used selectively, especially for instance in Pakistan against Western organisations who are accused of anti-Islamist values, or in Nigeria, against groups which officials may falsely claim are supporting terrorism, as seen in the closure of the Action Against Hunger offices, a charity based in Borno and Yoruba states. 


\section{Tightening of online space}

In each country the internet has become an increasing source of communication and mobilisation by activists and civil society, especially perhaps as the restrictions in the offline spaces increased. Yet this area too has seen increased restrictions, in common with global trends. Pakistan is regarded as 'not free' and Nigeria 'partly free' in the Freedom House 'Freedom on the Net' index in 2020 . In Nigeria legislation was passed in 2015 and 2019 to regulate social media and online speech, and allow prosecutions for statements and actions online. In Pakistan, the Prevention of Electronic Crimes Act 2016 (PECA) and Citizens Protection (Against Online Harm) Rules 2020 have empowered authorities to pursue activists and target commonly used platforms. The new press law in Mozambique included provision to regulate online journalism and online speech. These rules have been used selectively to target bloggers or citizen activists for 'cybercrimes' or messages that are regarded as hate speech or blasphemy, and there are growing concerns on the use of these to stifle dissent and free speech. Such attacks to the online space are not only through regulation. In Mozambique pro-Frelimo 'trolls' have become increasingly active in recent years, with a rising number of online attacks and threats against civil society leaders, journalists and opposition activists.

\section{Box 4}

\section{Limiting of media and press freedom}

Each country has an active press, yet each also ranks relatively low on the Press Freedom Index, ranging from Mozambique at 104th (out of 180 countries), Nigeria, 115th and Pakistan, 145th. In some cases there have been highly visible attacks on journalists who challenged government corruption publicly, or the closure of media offices. In Mozambique these include the attacks on well-known media commentators Erico de Salema and José Jaime Macuane, and the murder in 2015 of constitutional law professor Gilles Cistac after a media interview in which he expressed agreement with a decentralisation proposal that was in line with what the opposition Renamo movement was advocating.

\subsection{When the pandemic struck: Cases, policies, and narratives}

Mozambique, Nigeria, and Pakistan were hit quite differently, and at different points as the pandemic spread in early 2020 (see Boxes 5, 6, and 7$)^{\mathrm{e}}$. None reached the degree of transmission or fatality of the most-affected countries globally, or in the case of Mozambique and Pakistan even their near neighbours, although the extent of population testing and data quality issues almost certainly led to underestimates in these official reports. As Figures 2 and 3 on page 20 show, Pakistan saw the greatest reported health impact of the pandemic by the end of 2020 .

However, the global call to action from the World Health Organisation, scenes of overwhelmed hospitals in Western Europe, and rapid transnational diffusion of public policies seen as necessary to control the pandemic brought

${ }^{e}$ All commentary on reported case numbers in this section uses information from Our World In Data. Case numbers are as reported by John Hopkins University. 
about significant changes in each country from March onwards. In each country these policy responses included states of emergency or exceptional restrictions on individual freedoms, changes to health services, economic stimulus or protection, and relief or aid to those vulnerable to the shocks of the pandemic.

As well as similar policy responses there were similarities in narratives and discourse around the pandemic in all three countries, resonating with framings elsewhere. Most notably the initial transmission through cross-border and internal travel led to characterisations of the disease as imported. In Mozambique and Nigeria this was linked to foreigners and political and business elites travelling internationally. In Pakistan Shia Muslims returning from pilgrimages from high-prevalence Iran, and cross-border traders were vilified for carrying the virus. Where case transmission was slow to take off but severe social and economic limitations were imposed, rumours of the virus being a hoax, or less dangerous for non-Western countries, spread widely. As in many countries, concerns that the harm caused by closing down economic activity would out-scale the harms of the virus were commonplace.
Figure 2. Cumulative confirmed Covid-19 cases per 1 million population (31/12/20)

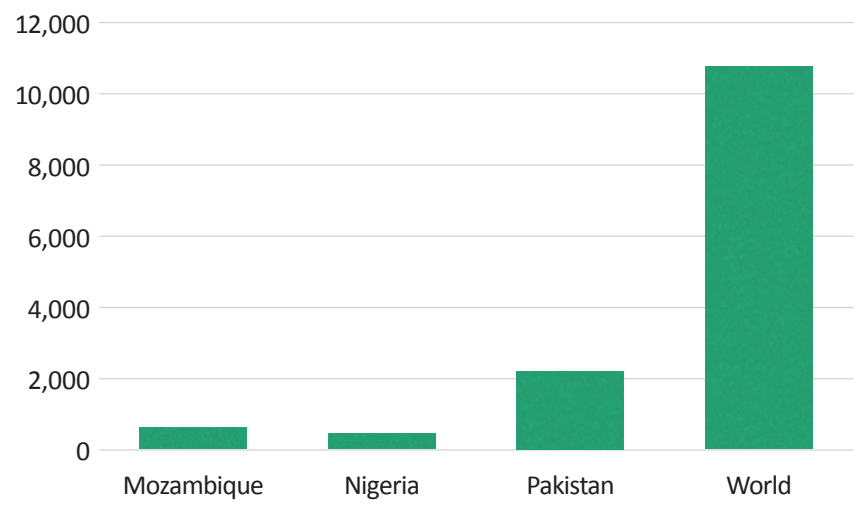

\section{Figure 3. Total reported Covid-19 related deaths per 1 million population (31/12/20)}

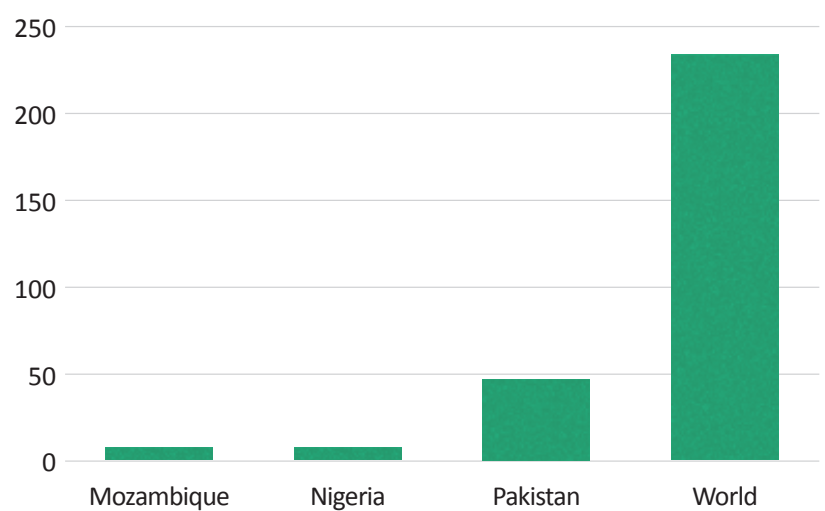

Source: Our World in Data, data from COVID-19 Data Repository by the Center for Systems Science and Engineering (CSSE) at Johns Hopkins University.

\section{Mozambique}

Mozambique had its first officially recorded case a few days after the pandemic declaration. The government responded with immediate border closures, closures of schools and bans on large gatherings, as cases rose in neighbouring South Africa. Shortly afterwards further restrictions on gatherings and business opening were announced. Reported cases remained low for several months, with the first Covid-related death reported at the end of May, and cases beginning to rise in early June. That increase continued slowly but steadily, overtaking the prevalence of the virus in Nigeria in early August and peaking first in early September. Restrictions were gradually lifted after this peak, as the rate of infection slowed, although the number of positive tests soared in January, potentially linked to the spread of the highly contagious South African variant as a result of Mozambican mine workers returning home from South Africa for the Christmas holidays and the seasonal influx of tourists from neighbouring countries. 


\section{Nigeria}

Nigeria reported the earliest first case of the virus of the three countries, but official statistics show only a slow increase in new cases in the early months of the pandemic. Nevertheless, the Nigerian authorities responded with significant and far-reaching policy responses, often 'borrowed' or imported from countries far harder hit and where health systems were being overwhelmed with patients. These included 'stay-at-home' lockdown orders and curfew restrictions targeted in areas of greatest infection, bans on travel, and closure of schools and businesses. In March an economic stimulus package was announced, although only for the formal economy, and in early April emergency payments to poor and vulnerable households on the National Social Register. After a peak in early July, newly reported cases levelled out at relatively low rates from September to December. A second wave of new cases took off in December, with the Nigerian Center for Disease Control issuing a new advisory notice and government ordering the re-opening of Covid-19 isolation and treatment centres previously closed.

\section{Box 7}

\section{Ic Pakistan}

Pakistan experienced the most pronounced and immediate 'first wave', with newly identified cases rising rapidly from March until a peak in mid-June, reporting the highest number of daily new cases in the world on 13 June $(6,825)$. World Health Organisation data identified Pakistan as the second hardest hit country in South Asia and with the fourteenth highest global case count at this point. Newly reported cases declined steeply between June and September, and the government was praised for its achievements, although some, including the Pakistan Medical Association, raised concerns about a lack of testing taking place ${ }^{51}$ During this period the government rolled out an Ehsaas emergency cash transfer scheme, which delivered USD1.1 billion to 14.8 million families at risk of extreme poverty ${ }^{52}$. The public health responses of 'smart lockdowns', curfews, bans on gatherings, closures of schools and universities, restaurants and some businesses were gradually lifted. Newly reported cases started to rise, at first slowly, and from late October rapidly, in a second wave that peaked in early December following the reintroduction of many restrictions.

\subsection{A year of intersecting crises}

In all three countries the shock of the pandemic coincided with other major events, including some that overtook the virus in public priority. These included continuation and flare-ups of long-standing conflicts, natural disasters, economic crises, and varieties of political tension. When the Mo Ibrahim Foundation published a report in August $^{53}$ on the views of young Africans on the pandemic its conclusion that the health effects of Covid-19 were dwarfed by other social and economic concerns, including those caused by pandemic responses, chimed with our cross-country research panel. In Northern and Central Mozambique, still struggling to recover from two severe cyclones which struck those regions in 2019, conflicts escalated over the course of 2020. The observatory panel in Mozambique included representatives from Cabo Delgado, where a jihadi insurgency that began in the coastal district of Mocímboa da Praia in 2017 rapidly engulfed most of the province, raising fears that it could spread into other provinces. They were clear throughout the research that conflict posed a far greater risk than Covid-19, and that civil society groups were more concerned about how the state of emergency closed down their space to provide humanitarian relief and document the actions of armed groups on the ground. Conflicts persisted too in Nigeria and Pakistan, raising similar concerns about civil society's ability to intervene, provide aid, and call for accountability. In August 
a flare-up of violence in South Kaduna, Nigeria led to displacement, deaths, and economic crisis in this already conflict-affected area. ${ }^{54}$ In Pakistan insurgency and military activity continued in Balochistan, and conflict persisted in Khyber Pakhtunkhwa, where civic space and freedoms were already significantly constrained according to activists on the ground. ${ }^{55}$ Early in the pandemic cases of Covid-19 in Mozambique and Pakistan were reported by our researchers to be higher in these areas of conflict, and Kaduna State became one of centres of the second wave in Nigeria.

Other crises overlayed this background of conflict and emergency response to the pandemic. In Pakistan severe rains in August caused floods, widespread destruction and deaths. ${ }^{56}$ Emergency relief by civil society groups and authorities overtook the pandemic in priority, and citizens challenged public health measures and instructions by protesting over the government's response. As debates were going on across the world on access to relief funds and social protection in the wake of the pandemic, people in the central region of Mozambique were still demanding relief funds promised in the wake of Cyclone Idai in early 2019..$^{57}$

As the pandemic wore on the global economic effects gained more prominence. In Nigeria, the heavy economic dependence on oil caused a severe economic shock as the pandemic led oil demand and prices to drop, impacting public finances hugely. ${ }^{58}$ Stay-at-home orders also greatly affected agricultural production. Immediately after lockdown measures were lifted students took to the streets to protest over increases in electricity and fuel prices. ${ }^{59}$ In Pakistan, the combination of lockdown impacts on the informal economy, soaring inflation and rupee devaluation meant that the lowest paid were struggling on significant real-terms cuts in their income. The deteriorating global market for natural gas combined with the growing insurgency in Cabo Delgado (site of Mozambique's largest gas fields) led several global energy companies to cancel or postpone their investments in the Mozambican gas sector, devastating the government's revenue outlook and increasing popular frustration after many years of raised expectations.

Other forms of political crisis and contestation continued throughout the pandemic. In Mozambique government transparency and accountability around the use of new oil and gas revenues became a central point of contention, notably in calls to create and transparently manage a sovereign fund. In Pakistan opposition parties came together in coalition towards the end of the year to attempt a unified front against the governing party (Pakistan Tehreeke-Insaf - PTI) and the 'militablishment', and actions by the banned PTM movement continued. In Nigeria long-standing grievances on corruption, and poor governance, and police brutality fuelled a number of protests against the government with calls for accountability, most notably in the EndSARS protests and subsequent disorder in October.
BELOW

Many were displaced and moved to temporary accommodation in the conflict hit region of Cabo Delgado during the year (Image from Metuge village, June 2020).

PHOTO: MIROS LAV, SHUTTERSTOCK.COM

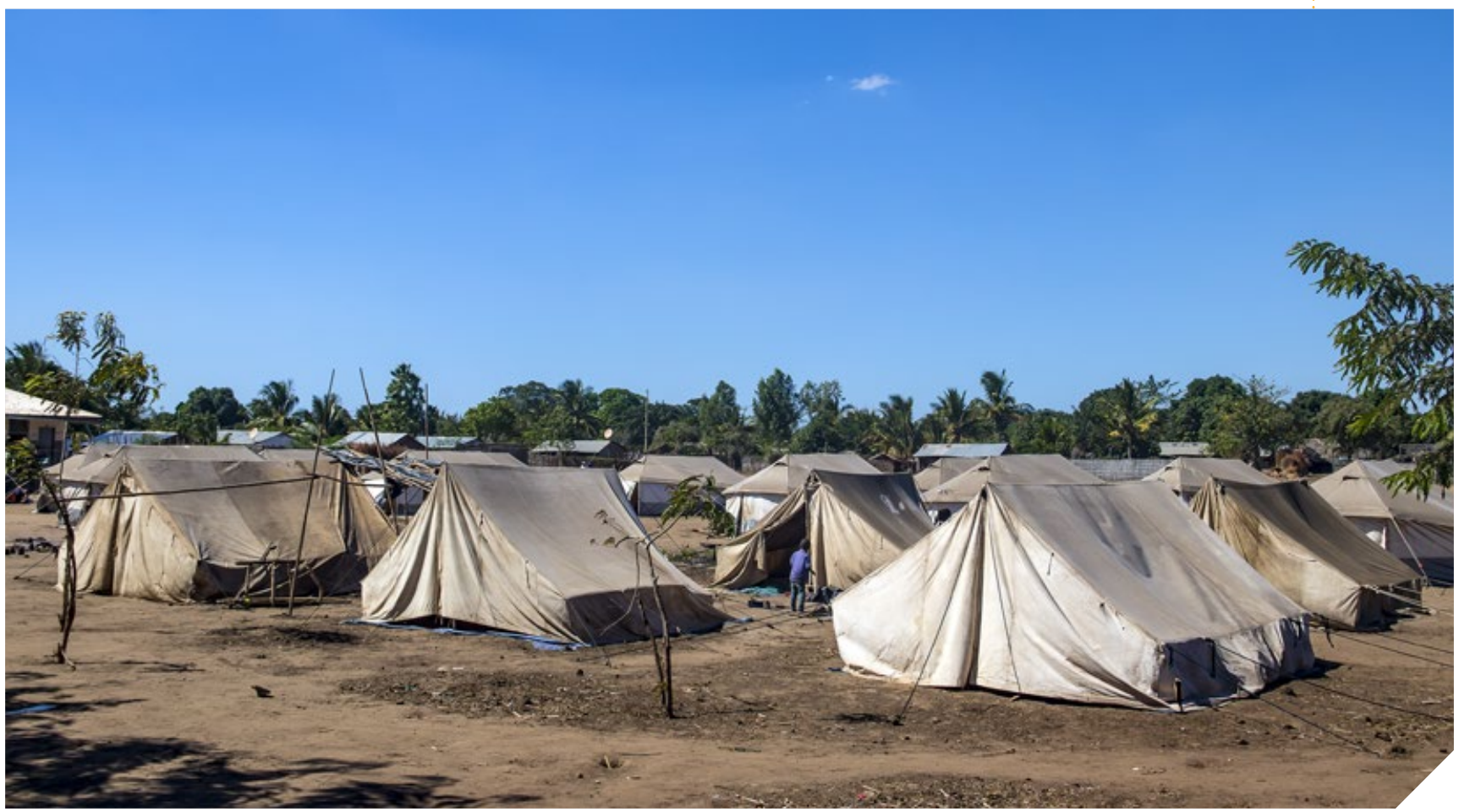




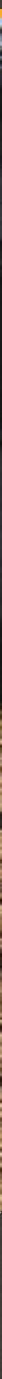

The pandemic hastened and magnified previous trends of civic space closure in Mozambique, Nigeria, and Pakistan, both offline and online. The crisis gave cover and impetus for further repression and attacks by authorities, intensifying the rejection of critical voices. Space was not only closed further for critics of government, but forces of division grew, riding on the stigmatisation of others, internal conflicts, and competition for resources.

ABOVE

Activists from Mozambican NGO Ophenta campaigning against the spread of Covid-19 in the province of Nampula, September 2020 PHOTO: OPHENTA 
A key feature of the global commentary on Covid-19 and governance is the opportunity and impetus it gave for authoritarian and autocratic moves by governments and political elites. Faced with a crisis with many unknowns and pressure for rapid action, emergency powers were taken quickly by authorities in Mozambique, Nigeria, and Pakistan. A wave of restrictions on daily life followed. However justified on public health grounds, these restrictions were widely abused. The 'securitisation' response spawned numerous rights issues, with police and security services particularly guilty of over-reach and opportunism. Rules were not only over-enforced, but enforced selectively to target dissent and critique of government's pandemic response and the social and economic fall-out each country experienced. Previous patterns of seeking to regulate the CSOs that ask difficult questions, and vilify and harass individual activists, continued unabated despite the public policy priority of pandemic relief and alleviation.

Beyond the most obvious restrictions on freedom of assembly, human rights abuses and examples of state over-reach during the pandemic, more insidious attacks on civic freedoms continued. Press freedom was consistently under attack, with reporting restrictions imposed on the pandemic and policy responses, as well as ongoing conflicts and popular protest. Critical journalists were threatened, harassed, subject to malicious investigation and prosecution, and in some instances 'disappeared'. 'Fake news' narratives were used to undermine their reporting alongside widespread disinformation campaigns by authorities and their allies.

Moves to control the debate and silence critical voices applied as much online as offline. As physical gatherings were restricted and unviable much civic action moved online, with some seeing a new era of 'digitivism' that broadened and amplified activist's voices and concerns. But attempts to undermine these spaces kept pace. Online harassment became an even greater issue. Authorities moved to regulate online speech and commonly used platforms, claiming this was to combat 'cybercrime' threats, 'fake news' or 'immoral', 'divisive' or 'anti-patriotic' content. In this highly charged atmosphere freedom of expression online paid the price, with our panellists reflecting on growing mistrust of information, and self-censorship by activists.
Alongside attacks on civic freedoms and space and intensified restrictions on CSOs, the pandemic exacerbated sources of division amongst civil society, and sometimes diverted civic energy along these lines. Long-standing social divisions and tensions were inflamed both by the pandemic and the response - whether in the stigmatisation of particular communities as 'carriers' of the virus, the selective application of rules to some identity groups but not others, or perceived discrimination in relief and aid. Sectarian divisions grew deeper, with accusations of blasphemy being 'weaponised' more than ever in Nigeria and Pakistan to silence critics and sustain grievances.

Tensions and divisions also played out between different areas in each country, and between central and sub-national authorities. The centralising effect of executive powers led to disputes with sub-national governance structures over pandemic management, differing rules, and allocation of resources. These overlaid the effects of ongoing conflict and natural disasters experienced in distinct parts of each country. For CSOs, whilst new opportunities for joined-up action presented themselves, there were also signs of fissures in relationships between national and urban-based organisations and those more rural and community-based.

Finally, the re-direction of public and international donor funds towards pandemic response provided important opportunities but also threatened to be divisive. Alongside many positive examples of new collaborations between civil society actors in the emergency context of the pandemic, explored in the next section, competition for new and dwindling funds on 'old' priorities threatened the solidarity of the CSOs. Such competition - framed by one panel as CSOs 'shrinking their own space' sat alongside decisions by authorities and funders to channel resources through less contentious and service oriented civic organisations.

\subsection{Executive over-reach, securitisation and suppression of dissent}

In common with many countries around the world, the pandemic triggered emergency legislation and 'lockdown' restrictions on public gathering, travel, education, and business in all three countries. On 30 March, the President of Mozambique addressed the nation and declared a State of Emergency 'for reasons of public calamity' 
for the first time in the nation's democratic history. On the same day in Nigeria the federal government signed Covid Regulations I, giving legal backing to lockdown restrictions already in place in Lagos, Ogun, and Abuja since 21 March. Simultaneously the province of Sindh in Pakistan initiated its first full lockdown, closely followed by the provinces of Balochistan, Khyber Pakhtunkhwa (KP) and Punjab. Pakistan also closed its border with Afghanistan and Iran, and held four thousand returnees from Iran in enforced quarantine. ${ }^{60}$

In all countries this represented a significant shift towards executive authority, with the threat of the pandemic triggering a firmly centralised approach that avoided well-established processes for public deliberation and participation. In Nigeria usual measures for triggering oversight of new legislation, requiring consultation and public and parliamentary debate, were avoided. In Pakistan a new body, the National Command Operation Centre was created to oversee the pandemic response, chaired by the Minister of Defence and involving several military representatives. ${ }^{61}$ The Pakistan observatory panel participants who saw this as the start of a 'clawback mode' from the military, seeking to regain some of the political power gradually devolved to provinces and the elected government, noted how the government issued regulations and actively avoided legislation to prevent parliamentary debate. In Mozambique, our panel saw the State of Emergency as significantly 'exaggerated' and violating fundamental rights, also noting that it was effectively extended beyond constitutional provisions through the passing of a new law in August.

Lockdown restrictions gave new space for 'overreach' from authorities, and in particular police and security forces. Lack of clarity on rules hastily enacted and poorly communicated gave free rein to a heavily securitised response to a public health issue. In Mozambique ${ }^{62}$ and Nigeria ${ }^{f}$ reports quickly emerged of excessive force being used to enforce lockdown measures. In both countries this included reports of not only arrests and extortion, but also allegations of extra-judicial killings by police for minor infractions like not wearing face masks in public. In Nigeria reports of police using the threat of lockdown enforcements to sexually assault women alarmed rights advocates, and police arrested people in border areas for breaking interstate travel bans whilst going about daily life. ${ }^{63}$ By July, a report by Bloomberg highlighted that the

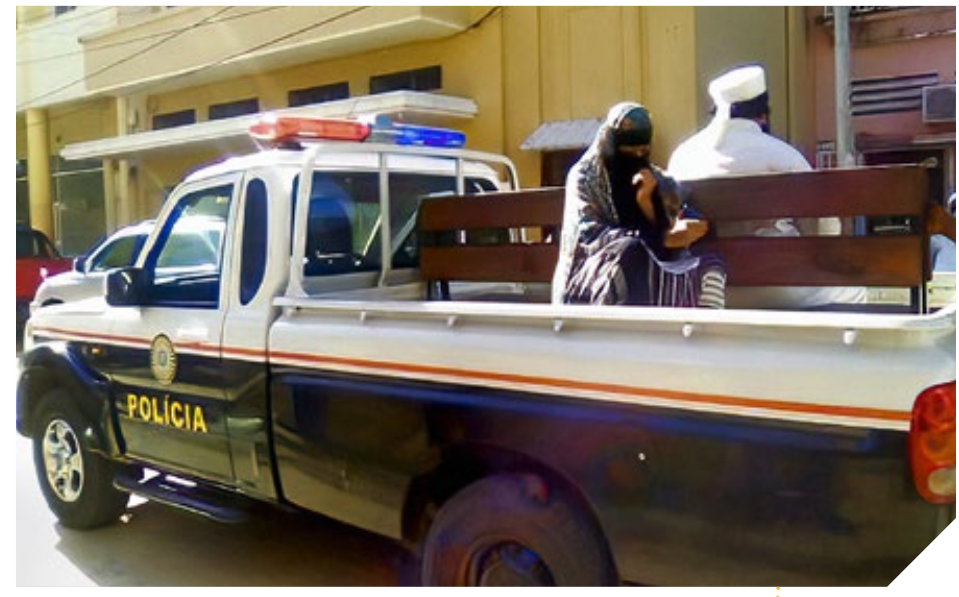

security response was 'deadlier than the disease'. ${ }^{64}$

Alongside these attacks on human rights, lockdown restrictions and the 'securitisation' response had an immediate effect in reducing civic space available to challenge authorities. With gatherings forbidden and new rules regulating freedom of movement, physical protests were banned, or heavily policed. In August Nigerian security forces arrested peaceful protestors in Abuja for violating social distancing rules, although these arrests were accused of being politically motivated. ${ }^{65}$ Demonstrations and political rallies in Pakistan were not granted permission on the grounds of public health ${ }^{66}$.

But these restrictions were not applied equally. In Nigeria mass rallies by political parties were allowed by the APC and PDP parties in the run up to the September 2020 governorship election ${ }^{67}$. These took place without social distancing measures and only shortly after demonstrators had been arrested for publicly gathering to demand better governance of the pandemic ${ }^{68}$. This, and impressions that the political and economic elite were still able to gather in large numbers for burials and weddings, was seen by our panel to be 'powering narratives that Nigerian elites and political class are above the $l a w^{\prime}$. During conflict in southern Kaduna in June there were also reports of the discriminatory application of curfew laws, with indigenous farmers told 66 The pandemic fuelled new forms of human rights abuses under the cover of new restrictions and public health measures.99

to stay inside whilst herders were not punished for grazing freely on their farms ${ }^{69}$. In Pakistan, the new rules and public health justifications were used selectively to target opposition voices. Sectarian

${ }^{\mathrm{f}} \mathrm{See}$ Closing Spaces Database for examples from Nigeria: https://closingspaces.org/covid-19/ 
religious organisations were permitted to hold anti-Shia rallies and gatherings of hundreds of thousands whilst opposition parties were ordered not to gather ${ }^{70}$, and bans on public gathering were seen to be used strategically by the ruling party, for example being issued the day after the GilgitBaltistan elections in November ${ }^{71}$.

In all three countries the familiar tactic of forced disappearance continued, arguably made easier by stay-at-home orders. In Mozambique and Pakistan cases were noted to particularly affect journalists - in the former those reporting from the conflict-affected Cabo Delgado ${ }^{72}$, and in Pakistan those questioning the securitisation of the state ${ }^{73}$. In Pakistan forced disappearances have long been an issue in the provinces of Khyber Pakhtunkhwa and Balochistan, and were reported as increasing in Sindh. In Nigeria, our panel highlighted how the closure of the court system for public health reasons took away one route for civil society actors to challenge unlawful arrests and detentions. Following the EndSARS protests in October numerous reported incidents of missing persons were highlighted by civil society watchdogs ${ }^{74}$.

As the first wave of transmission waned, the securitisation trend continued, and restrictions on civic freedoms persisted, and were taken advantage of by the establishment. In Mozambique, the State of Emergency was extended three times, and a new Act of Parliament passed in August allowing a new 'state of public calamity' to be announced by the President for an undetermined period ${ }^{75}$. In Nigeria, the federal government introduced new legislation, the Infectious Disease Bill 2020, that sought to grant powers to law enforcement officers to apprehend people suffering from infectious diseases, and unparalleled powers to the Nigerian Centre for Disease Control to detain members of the public and minors indefinitely ${ }^{76}$, which members of our panel referred to as containing 'omnibus' clauses that dramatically empowered the state.

During the pandemic long-running attempts to increase state powers to regulate civil society actors continued. In Pakistan official registration requirements for $\mathrm{CSO}$ s have increased and been used to pressure and limit the freedom of civic actors. Since 2019 federal and provincial governments have been pressured to create new Charity Commissions, increasing the number of bodies that CSOs need to register with and that can restrict their operations ${ }^{77}$. Shortly following the first wave of the pandemic the Punjab government made it mandatory for all NGOs to register with the Punjab Charity Commission within 30 days $^{78}$. In other provinces major national advocacy organisations had their registrations revoked under similar rules. Our panel noted that divided by this and similar requirements CSOs resorted to lobbying to gain individual exemptions. Such regulation often happens under the guise of efforts to eliminate terrorist and proscribed organisations, or prevent financial crime. In Nigeria, the Companies Allied Matters Act, on the table prepandemic, was passed in August. The Nigerian Action Group on Free Civic Space pointed out that although the act was meant to focus on corporate governance, it actually empowers authorities to restrict CSO operations and freedom of association ${ }^{79}$. CSOs that had supported EndSARS protesters and joined their calls for accountability were subsequently placed under state surveillance and several de-registered in an attempt to silence them ${ }^{80}$.

Individual activists and dissenting voices were also pressured by authorities, and punished for their protest actions during the year. Across cities in Pakistan students mobilised in November in the third annual Student Solidarity March adding the problems that emerged in Pakistan's education system since Covid-19 to their existing demands ${ }^{81}$. After the Lahore event a detention order was issued against academic and activist Ammar Ali Jan ${ }^{82}$. The way he was described in that order, as a 'symbol of frightens' [sic], took off on as a hashtag on Twitter, mocking the authorities, but also indicating the way that such actions are intended to instil a climate of fear. In Nigeria, the response to EndSARS by the government included targeting of individual activists and supporters for arrest, with travel bans or passport removal, or with blocking of individuals' bank accounts ${ }^{83}$. Authorities also targeted activists through the courts, for example listing prominent celebrities as defendants in a lawsuit accusing them of using their Twitter accounts for the the promotion of unlawful assembly'84. In Mozambique, a strike coordinated by business owners in the second-largest city, Beira, which closed businesses for three days in protest at insecurity and a spate of kidnappings, was met with threats to fine businesses for actions 'contrary to public interests' ${ }^{85}$.

\subsection{Freedom of press and of expression}

Press freedom was under pressure in all three of our countries, as the pandemic heightened sensitivities of those in power and exposed them to critique. In Nigeria data gathered by Spaces 
NAVIGATING CIVIC SPACE IN A TIME OF COVID: SYNTHESIS REPORT

CIVIC SPACE DURING THE PANDEMIC

for Change indicates an increase in attacks on freedom of speech during the year. In March the Nigerian Presidency barred some media outlets from covering its activities, limiting their ability to cover the pandemic response. During the EndSARS protests photo-journalists were reported to be targeted and attacked by security services, and news outlets fined and threatened with closure by the National Broadcasting Commission for 'unprofessional coverage' of the protests. In Mozambique, the offices of newspaper 'Canal i' were attacked and set on fire in August, four days after publishing an investigation into fraudulent contracts that benefitted the party elite ${ }^{88}$. Press access and media reporting on the conflict in Cabo Delgado was greatly impaired, with journalists arrested or disappeared. All but one local radio station in the region was reported as still operating by November, and observatory panel members suspected that TV news channel coverage was being controlled by authorities.

In Pakistan journalists critical of the ruling party or military continued to be targeted by the authorities, with pressure taking many forms. Several disappearances or kidnappings of male journalists brought about protests. Female journalists were subjected to sustained harassment and death and rape threats online (see Box 8). For some women, negotiating space from their families to continue working has become more difficult as a result. In August a group of well-known female journalists submitted a joint statement highlighting this harassment by individuals linked to the ruling party, highlighting that those who had criticised the government's handling of the pandemic were especially targeted ${ }^{89}$. Numerous journalists remain under investigation by the Federal Investigation Agency (FIA), according to the Pakistan Federation Union of Journalists ${ }^{90}$. In July, shortly after press outcry over another disappearance, a para-military force called the Rangers raided the Karachi Press Club ${ }^{91}$. The Pakistan observatory panel also discussed instances where media outlets appeared to be punished with loss of advertising where their coverage was critical of the government. They agreed that government insistence that journalists should remain 'neutral' in their reporting was 'doublespeak' for expecting coverage to be favourable to the establishment.

In the context of uncertainty and conflicting information that the pandemic brought, and in keeping with the emerging tactics of authoritarian
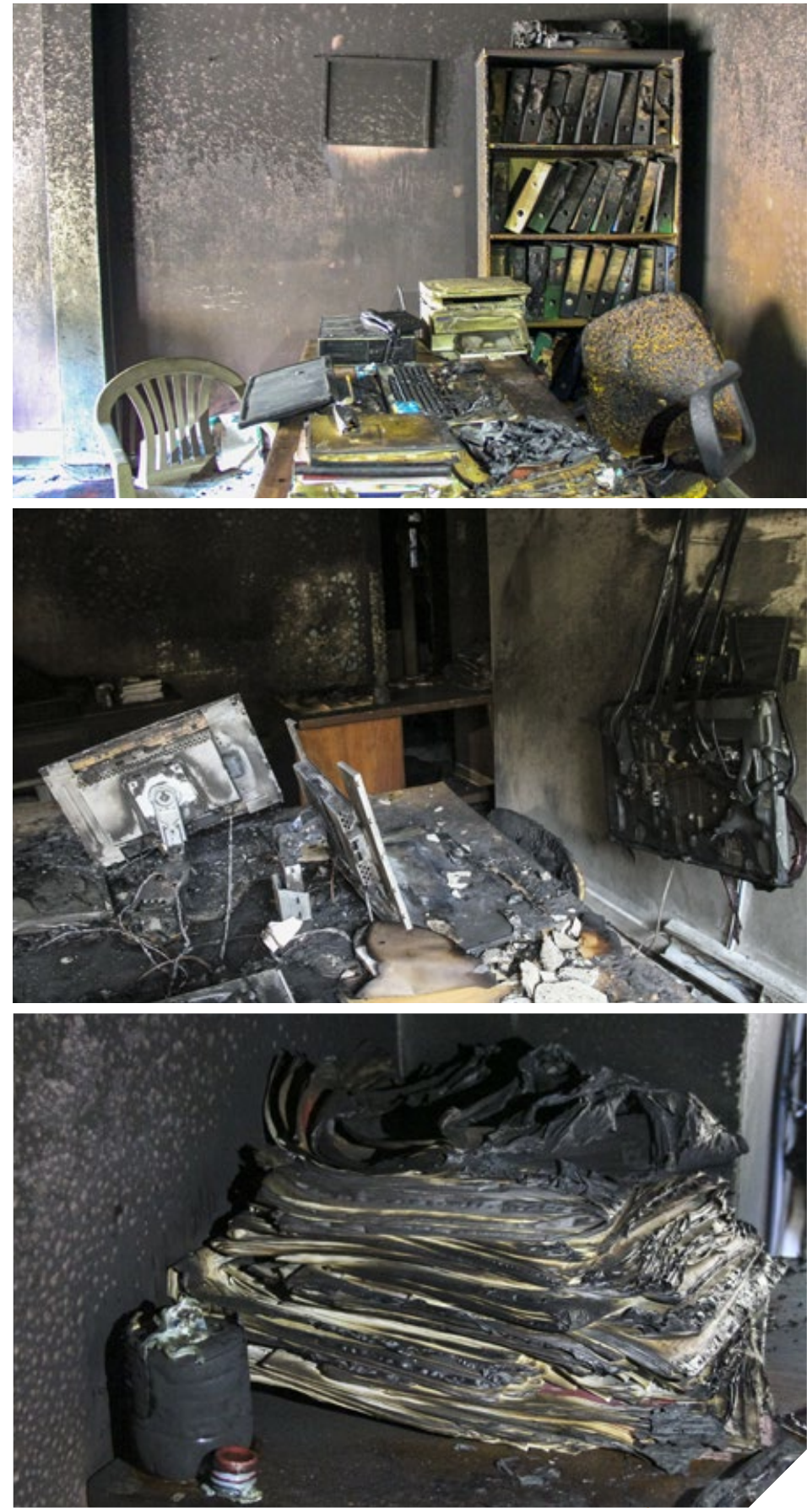

leaders worldwide, accusations of 'fake news' were targeted by governments to undermine independent reporting and narratives. In Mozambique the President publicly accused the independent press of spreading fake news in November, specifically related to their coverage of the conflict in the north, and encouraged the military to suppress such coverage ${ }^{92}$. In Pakistan journalist Ahmed Noorani's exposé on a prominent political aide led to him being accused of spreading fake news, with a news channel accusing him of working for anti-state interest - an accusation that spurred death threats online ${ }^{93}$. In Nigeria
ABOVE

Offices of the independent media house Canal de Moçambique following publication of investigations into state corruption, August 2020. PHOTO: LUCAS DE MOÇAMBIQUE 


\section{Case study: Online harassment and persecution of female journalists in Pakistan}

Benazir Shah, editor at the Geo News, was active in investigating Covid-19 in Pakistan since the start of the pandemic, writing several news pieces about its emerging impact and posting daily updates of cases and deaths that she received from official sources on her Twitter feed.

Shah and other female colleagues who published this kind of critical coverage of the pandemic response were subjected to a wave of sexual harassment and abuse online, which they suspect was coordinated by the ruling party.

Shah explains, 'Since I began Covid reporting [...] my timeline would just be flooded with abuses'. She says the harassment campaign is intended to 'target women journalists so much that they stop tweeting ${ }^{\prime 95}$. Sadly, male journalists also suggest that their female colleagues stop using Twitter, not understanding that social media is the only platform for them to raise their voice in a climate of shrinking civic space. Similarly, Ailia Zehra, a journalist with digital news platform Naya Daur, published an article in early March highlighting that Imran Khan's statements about the virus and its transmission did not reflect WHO guidelines.

She has since been trolled many times on Twitter, but recently the ruling party shared a doctored video of Zehra on Twitter, increasing the pressure. Zehra claimed that, 'The Covid situation exposed the government's incompetence and its inability to deal with such a situation which is what we reported. This is why government trolls tried to silence us. And of course women journalists are an easier target $^{\prime 96}$.

Even those supposed to regulate online media are implicated. Recently the FIA charged nine women journalists under the PECA after an alleged sexual harasser, a well-known singer, filed a defamation case against them for their coverage of a case of sexual harassment he allegedly committed. Although Zehra provided proof of death threats and rape threats on her Twitter account and personal WhatsApp number, the FIA instead helped the alleged harasser to place defamation charges against women journalists, activists and lawyers ${ }^{97}$. authorities responded to the EndSARS protests by spreading disinformation on CSOs and outlets involved in reporting and assisting the campaign ${ }^{94}$.

The upshot of both targeting of critical journalists and accusations of fake news is significant. Our panels reported that even independent media outlets can no longer be trusted to reflect the situation on the ground, silenced through self-censorship in an atmosphere of fear. This applied in both traditional outlets and online publications and sources.

\subsection{Tightening online space}

The public health measures of the pandemic closed down many 'offline' spaces for protest, hastening a move to online spaces. However as civic action moved online, so did efforts to undermine and regulate it, and silence critical voices. One of our researchers spoke of the surge in digital action as a 'moment in the sun' before authorities caught up, and another about social media as a 'doubleedge sword' for activists given their subsequent targeting by authorities. Some of the pressure online came from direct harassment and threats. As noted above, women journalists who reported against the government's narrative on its Covid-19 response in Pakistan found themselves targeted with online harassment and trolling. One described her Twitter timeline being 'flooded with abuses ${ }^{\prime 98}$. Pressure also came from increased
66 The more the civic space expands beyond the traditional media outlets, the streets and town halls, the wider the dragnet of targets of governmental crackdowns.99

- NIGERIA RESEARCH TEAM 
use of the online space for state surveillance of activists. Our cross-country observatory panel noted the ways that such attacks led to selfcensorship by activists, stopping them from speaking out in fear of reprisals.

Legal regulations were used in both Pakistan and Nigeria to increase state control of digital tools and spaces and limit free expression. In Pakistan the PECA was used to investigate and arrest journalists for their online posts, accusing them of defamation. Stricter rules on social media companies, including sharing unencrypted data with authorities, were introduced early in $2020^{99}$. A variety of popular apps were banned during the rest of the year, with some suggesting that the block on TikTok was related to the emergence of political content on the platform ${ }^{100}$. The Supreme Court hinted at the possibility of re-instating a ban on YouTube for inciting hatred against members of the judiciary, government, and armed forces ${ }^{101}$. In October 2020 new regulations were passed under the PECA requiring data localisation, and granting further wide-ranging powers to the Pakistan Telecommunication Authority to determine what content is unlawful and issue blanket bans, including for material that threatens 'public order $^{\prime 102}$. In Nigeria, the 2015 Cybercrime Act has often been used to intimidate online journalists and citizens $\mathrm{s}^{103}$ and terrorism legislation was also used to target and detain individuals for online posts critical of government ${ }^{104}$.

\subsection{Social division, stigmatisation and polarisation}

Across countries, the response to the pandemic exacerbated existing social divisions, with both discourse and action playing into tensions between communities, and the pandemic hitting those already excluded or vulnerable harder. A more fractious and antagonistic public debate raised the stakes for those acting in civic space, particularly those acting for the needs of oftenstigmatised minorities.

In the early days of the pandemic, before cases were widespread and community transmission accepted, it was often framed as an 'imported' virus, and supposed 'carrier' population groups stigmatised. In Mozambique, the arrival of the virus in Maputo via a senior Frelimo figure who contracted it on a visit to London was widely discussed, intensifying perceptions of Covid-19 as an 'elite' or 'foreigners' disease, but as it spread to the North popular narratives began to stigmatise local religious and ethnic minority groups as carriers of the virus ${ }^{105}$. In Pakistan, the focus from media and government on the risk of the virus spreading through those returning from religious pilgrimage to Iran, and the migration along the Iran and Afghanistan borders reinforced anti-Shia and anti-Hazara sentiments, who were blamed by some for importing the virus ${ }^{106}$. One of our panellists explained in June how members of the Hazara ethnic group in Quetta were increasingly experiencing mob attacks and persecution by officials in the light of this stigmatisation. As noted above, quarantine centres set up in border crossing towns became key sites of virus transmission amongst an already marginalised group ${ }^{107}$.

As transmission spread and the parallel actions of authorities
66 In the wake of the pandemic, social media apps are crucial to foster dialogue and debate but the state refuses to stop moral policing and censorship which ultimately restricts the country's civic space. 99

- PAKISTAN RESEARCH TEAM to enforce lockdown measures

and provide targeted relief ramped up, further tensions were inflamed. In Nigeria conflict reignited in South Kaduna, where stay-at-home orders and curfews were more strictly enforced for minority ethnic and Christian farmers, increasing their vulnerability to a resurgence of violence from other groups ${ }^{108}$. Our panel highlighted how the enforcement of these orders prevent community self-organising for relief or protection, and external aid to those affected by the conflict. One of our members reported that this new wave of violence during the pandemic further fuelled debates about the perceived bias of the Kaduna State Government against the Christian minority populations.

In Pakistan discrimination surfaced as it has done before in how humanitarian relief was distributed, both in relation to Covid-19 and flooding, in particular to non-Muslims. Civil society protests broke out in Karachi accusing relief workers of being reluctant to provide relief goods to the local Hindu population ${ }^{109}$. Against a background of stigmatisation and sectarianism, one panellist highlighted that anti-Shia wall chalking - a common practice in Pakistan during the 1980s - was reappearing in Karachi ${ }^{110}$.

These specific examples sit against a growing sectarianism experienced in Pakistan across the year ${ }^{111}$. One expression of this, also noted in 
Nigeria, came to be referred to in our discussions as 'the weaponisation' of blasphemy accusations. Our panel observed that the pandemic's first six months saw a sudden and disturbing increase in blasphemy accusations and associated vigilante actions in Pakistan. There was a particular surge in accusations against Shias in Pakistan in August around observation of Muharram, and numerous journalists had similar charges laid against them in the courts across the year ${ }^{112}$. Although accusations came from multiple directions, our Pakistan panel saw these as a coordinated campaign to sustain insecurity and conflict, and reinforce the role of the military and federal government, particularly in Sindh and Balochistan. Often they were more blatantly political, using the blasphemy charge as a tool of persecution and harassment. A politician from the ruling PTI filed a blasphemy complaint in July against Khwaja Asif, an opposition politician, for saying that all religions are equal ${ }^{113}$. In Nigeria Mubarak Bala was arrested for blasphemy in April, and transferred to Kano State, known for its intolerance for religious dissent. Mubarak was detained in solitary confinement, without access to representation, and un-charged for months. Our panel discussed how others accused of blasphemy couldn't access legal support given the lockdown measures and fears amongst lawyers that they would be targeted with violence for being involved in these high-profile cases.

\subsection{Centralisation and sub-national divergence}

The need for decisive action in the face of the pandemic not only saw the shift of power towards the executive or military discussed above, but also a centralisation of authority and increasing tensions between national and sub-national authorities $^{115}$, with consequences for the locally empowering and democratising effects - actual or potential - of each country's decentralisation trajectories to date.

In Mozambique, our panel saw the State of Emergency as centralising decision-making further still in a context where local authorities lacked significant discretion in the first place. In Pakistan, the federal government revived the debate over decentralisation itself, suggesting revision of the $18^{\text {th }}$ Amendment of the Constitution that provides for devolved budgets and authority ${ }^{116}$.

There were differences in approach to the pandemic between national and sub-national

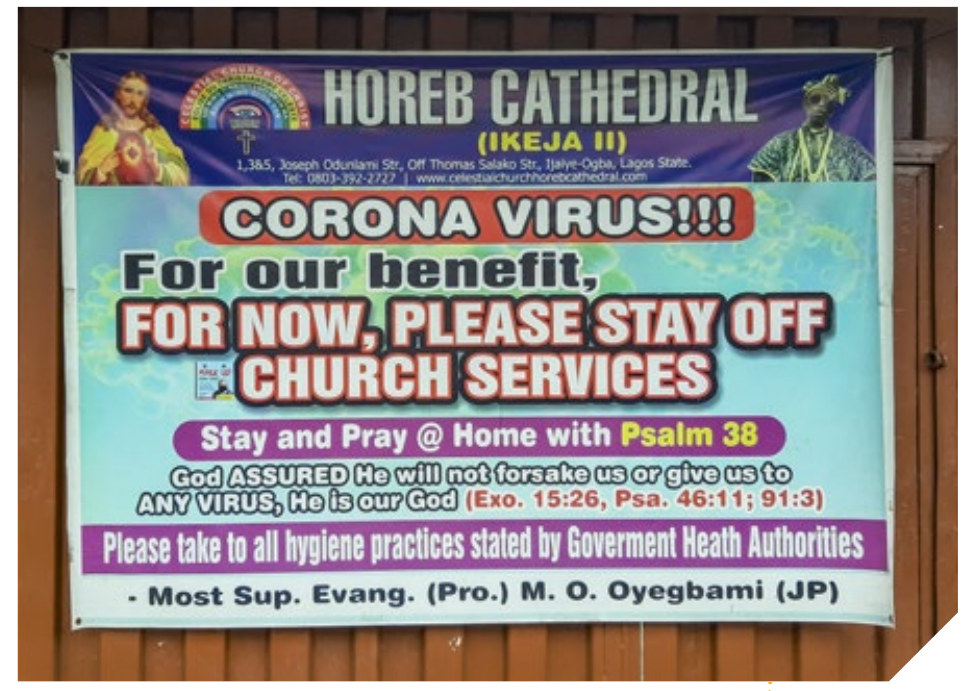

authorities. In Pakistan provincial governments took different public health approaches to the federal government. One activist in Sindh spoke of people being 'trapped between two narratives' one of the Sindh Government emphasising WHO advice, and a national narrative that initially at least downplayed the severity of the virus and opposed lockdown measures on economic grounds. Broader political tensions informed this, with Sindh the only
ABOVE A billboard at the entrance of a church in Lagos, asking worshippers to stay at home due to the pandemic, June 2020. PHOTO: OLUWAFEMI DAWODU, SHUTTERSTOCK.COM province not governed by the national ruling party, PTI, and further conflict between the two levels of government across the year ${ }^{117}$. In Nigeria, our panel discussed examples of inconsistency between national and state or local regulations, which meant that companies complying with regulations set by federal government were found to be violating local laws.

There were also tensions around distribution of pandemic relief and aid. In Nigeria State Governors of oil-producing states claimed that they were overlooked in the 'palliatives' of Covid-19 relief ${ }^{118}$. In Pakistan, our
66 The pandemic's first six months saw a sudden and disturbing increase in blasphemy accusations and vigilante actions which the government appeared unsure whether to condemn or condone. 99

- PAKISTAN RESEARCH TEAM panel heard reports of

political friction when the federal government refused emergency assistance to the Government of Balochistan to provide relief rations for those in quarantine.

These tensions and differences combined with the sub-national conflicts going on in all three countries to make civic space far from uniform across their territories. The unevenness of civic space had different characteristics in different places. In 
Mozambique, our panel saw not only significantly more curtailed space in areas of conflict, but also urban/rural divides. Organisations outside of the capital were reported to be less able to adapt to online forms of action and support, given lower levels of connectivity, resources, and skills. It is notable that a coalition of CSOs that came together to monitor Covid-19 emergency funds (discussed more below) included no organisations outside of the capital, Maputo. In Pakistan, the differences in more conflictual areas, where disappearances and lack of access to information were more common, and in opposition-run Sindh were seen as crucial to understand experiences of civic space. For our Nigerian panel, the exploitation of tensions in states like South Kaduna and Kano highlighted perceived differences in freedoms in the South versus the North of Nigeria. They reflected that civic actors in the North were more vulnerable to crackdowns linked to freedom of expression relating to faith, religion and morality while their counterparts in the South were more likely to get into trouble for critical commentary directed at state actors.

\subsection{Shifts in funding flows}

The pandemic put significant financial pressure on governments and civic organisations alike. The need to re-direct resources to pandemic response had its own impacts on civic space, including re-direction of donor funds that previously supported a wider range of CSO activity (a trend also evidenced globally ${ }^{119}$ ). This led to changes in the landscape for CSOs in our three countries, including exacerbating divisions amongst civic actors.

In our three contexts international funding of civic organisations, and particular larger CSOs, has been important historically in sustaining their role in civic space. The re-direction of funds to Covid-19 relief had both positive and negative effects. In Mozambique and Pakistan, it increased the pressure on advocacy and rights-based organisations that were already facing significant funding problems, threatening to remove these voices from the civic arena. In Pakistan, in contrast to previous emergencies, our panel observed that NGOs working on advocacy and with more of a rights orientation were quietly side-lined from the emergency response to Covid-19, despite having a potential role to play. Their view was that donors' decisions on which NGOs to fund were influenced by government preference to more service-oriented, less politically challenging, organisations. In Mozambique there was also significant concern amongst our panel that funds were being re-directed to Covid-19 away from the needs of displaced communities and human rights defence in conflict-affected areas. In both Mozambique and Pakistan the increase in funding flowing through state institutions was seen to increase the risks of co-optation of civic actors by authorities. More positively, researchers in Nigeria observed a more positive pattern of donors giving CSOs more flexibility in how they responded and reoriented their work to immediate community needs, recognising their networks and grassroots links.

In this context of changing funding, there were points where our panels saw competition between CSOs increasing, weakening the potential for collective voice 36 In recent years, Mozambican civil society has tended to segment itself more and more and with an internal struggle to seek protagonism, which ends up weakening its activism. and coordinated action.

Examples of this came to be discussed regularly in our project's observatory panels. Competition for funds was considered a major barrier to the success of CSOs in Mozambique and Nigeria in particular. In Mozambique this was referred to as the 'struggle for protagonism' - with organisations seeking to be lead partner in consortia, or managing funds on others' behalf, or being seen to be the most effective in responding to the pandemic. Panel reflections felt that this built on pre-pandemic patterns that had limited how far CSOs had managed to impact on governance in Mozambique. Competition over funds was one of the ways that our Nigerian panel observed that civil society actors 'shrink their own space'. In both countries this played into geographic differences. In Mozambique our panel observed that Maputo-based organisations were better placed to find funding, leaving provincially-based organisations vulnerable. A similar reflection on the concentration of funds on urban-based organisations was made in Nigeria. 


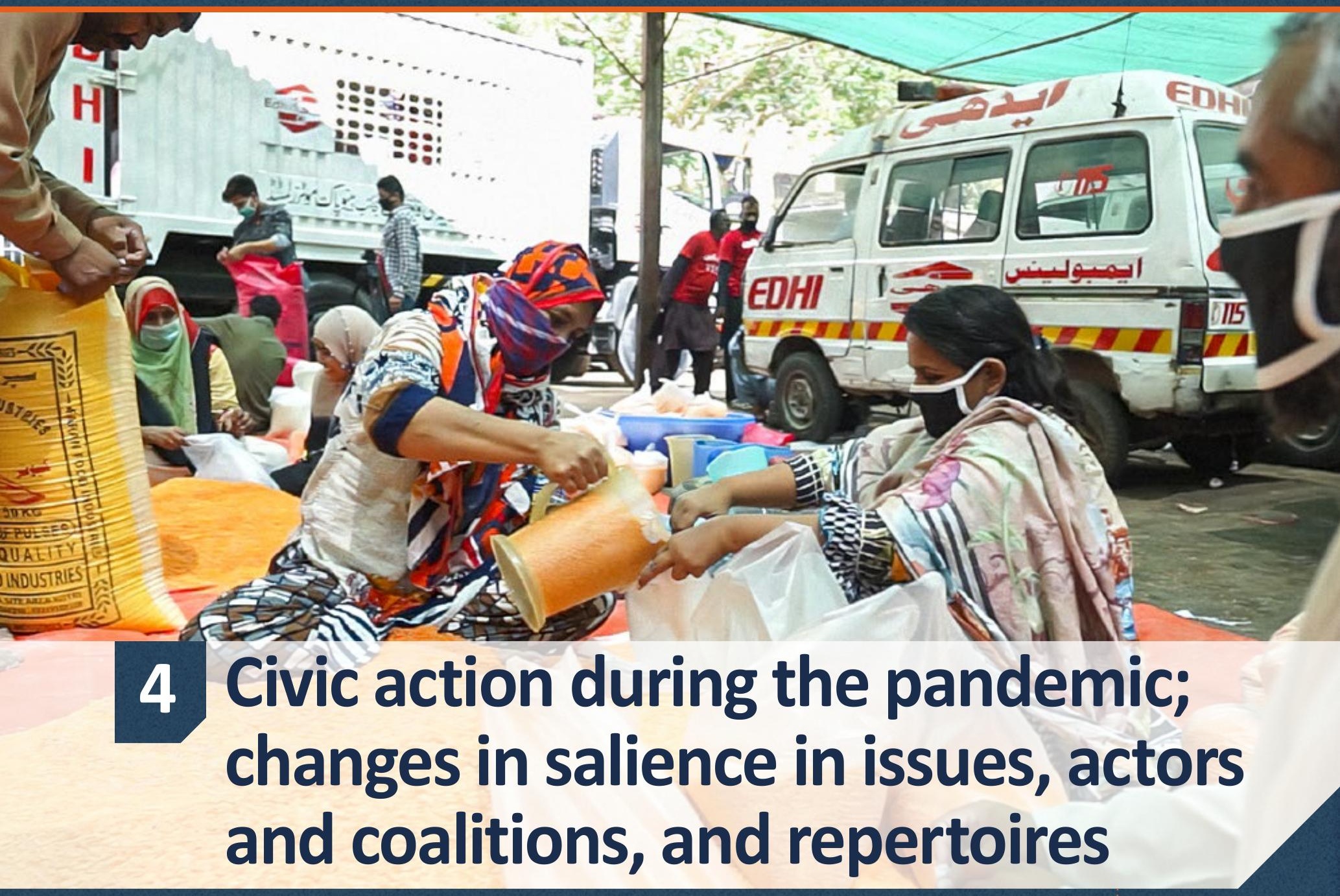

During the pandemic a host of public policy concerns became newly or especially salient, and much civic energy and action shifted towards these. Action on these issues drew in and brought together new actors and new coalitions, sometimes expanding the repertoires of action they used to navigate the available space.

ABOVE

Women prepare emergency food rations for

distribution in Pakistan. PHOTO:
KHIZER HABIB

This came about in part as issues that were most affected by the pandemic grew in salience, but also in more subtle ways, as the pandemic laid bare the unfairness of the status quo. 
I mportant shifts have occurred in civic action in Mozambique, Nigeria, and Pakistan since the onset of the pandemic, in some cases because of, and in some cases in spite of, the narrowing and more repressive civic space documented in the previous section.

We cannot say that these changes are directly driven by the pandemic and countries' responses to it, but they are clearly associated with it. None of the civic action observed is completely unprecedented: what has changed is the salience of particular issues, kinds of actor, and repertoires of action during this period.

The pandemic shifted attention and civic energy towards certain issues that stood out in a global and national public health emergency situation. Civic action focused on issues such as health and emergency relief, directly relevant to controlling the spread and effects of the virus, and on areas of life that were disproportionately affected by government responses to the pandemic, such as gender-based violence, livelihood struggles, education and law and order ${ }^{120}$. While these issues were not invisible nor uncontested before the pandemic, they grew in salience as a result of it.

Drawn out by the changing salience of issues, new actors and new coalitions came to the fore, sometimes out of necessity and other times as a strategic response. With them came adaptation and expansion of the usual repertoires of action, so that civil society actors could better navigate the available space. More unruly repertoires were on the ascendant, and citizen oversight mechanisms arose to monitor Covid-19 emergency relief, driven by a sense that mismanagement of these funds undermines the moral economy of society. The shifts in repertoire reflect declining trust between citizens and governments at this juncture where the status quo within societies has been laid bare and its fairness deeply and often indignantly questioned.

Online space became all the more important and an increasingly powerful arena for activism and dissent ${ }^{121}$. This activism included the involvement of wider groups of citizens in public debate and calls for government action. Numerous successful examples of 'digital protest' and online petitioning through hashtag campaigns emerged during the pandemic period ${ }^{122}$. In Nigeria, our panel saw online activism, for example through Twitter and Facebook, allowing citizens to circumvent restrictions on traditional media, and to 'speak truth to authorities' with less fear of reprisal. Social media and digital technologies also allowed rapid sharing of eye-witness evidence of what was happening on the ground, for example in the EndSARS protests in Nigeria ${ }^{123}$, enabling activists to counter official narratives. In Mozambique, our panel noted that for established CSOs the shift to communicating online widened their audiences and re-connected them with their constituencies, though it also intensified the gap in visibility and voice between Maputo-based and local NGOs. Digital technologies allowed new networks and connections to be built - sometimes reported to generate social capital that could feed both online and offline activism.

In the sections that follow we explore these general trends through the lens of civic action on six especially salient issues.

\subsection{Healthcare}

It is no surprise that the pandemic put public healthcare systems under the microscope, with health systems worldwide struggling to cope, and healthcare workers on the frontline of the fight against the pandemic. Correspondingly, these workers and their allies have mobilised across the world to demand more resources, greater protection in the form of PPE and risk payments, and greater recognition. Projects like the Accountability Research Center's health worker protest project have been tracking and compiling these ${ }^{g}$. CSOs have responded in solidarity but also in the direct delivery of public health services, filling in for deficiencies in government responses ${ }^{124}$.

In Pakistan, many groups of health workers were already mobilising before the pandemic, challenging moves to privatise healthcare systems and campaigning on their working conditions. The crisis of the pandemic and its impact, including the deaths of medics and nurses from Covid-19, saw increasing action by the 'Grand Health Alliance' (GHA) bringing together previously mobilised doctors and Lady Health Workers with newly mobilised nurses and medical students joining campaigns that included boycotts, strikes, and demonstrations ${ }^{125}$. The Medical Association of Mozambique took court action against the Ministry of Health and the Ministry of Economy and Finance in October 2020 for not fulfilling promises to pay overtime and risk subsidies in relation to Covid-19126. In Nigeria, doctors and nurses also protested, including through strike action, at inadequate working conditions and provision of PPE, and unions campaigned successfully on issues of hazard allowances and life insurance ${ }^{127}$. The observatory panel and representatives of unions in Nigeria observed that this marked a change in strategy

${ }^{\mathrm{g}}$ See https://twitter.com/HealthWorkerPro 
for a previously conservative and less confrontational part of the workforce - 'reshaping the dynamics of medical activism' as health unions 'deepened their understanding of the interconnectedness and interdependence of all social and economic issues ${ }^{\prime 28}$. Helping these various attempts by health workers to make forceful demands on the system were a sense of public support for the vulnerability forced on them by the pandemic and the inadequacy of government responses.

Civil society actors in all three countries responded to immediate needs by repurposing their resources and networks to deliver health-related pandemic emergency aid, in line with the approaches identified in many other contexts, for example the strategies observed by Brechenmacher et al ${ }^{129}$. Sometimes this was a deliberate move to partner with government. In Mozambique, our researchers observed this to include a number of organisations who had previously taken a critical stance towards government, with some reflections that this was a 'win-win' strategy that also gave them space to operate on the ground and to monitor the implementation of Covid-19 strategies and funding by government. In Pakistan large non-profit health organisations were observed to be heavily involved in the response with government support - continuing a trend of government supporting civil society actors focused on service delivery rather than advocacy or campaigning.

Box 9

\section{Case study: Upheaval and unrest in Pakistan's health sector ${ }^{\text {h }}$}

The pandemic has put health service providers in danger of contracting Covid-19. It has also afforded them opportunities to build public support for their ongoing demands for improved working conditions.

In Pakistan, the pandemic added fuel to doctors' ongoing campaign against the privatisation of medical colleges and public hospitals, which is planned as part of the IMF-mandated reforms in the provinces. Doctors contend that privatisation would make healthcare less accessible to the poor and endanger their job security as government employees. When the Province of Punjab passed into law a reform of medical training in line with these reforms in March 2020, paramedics, nurses and young doctors across Pakistan mobilised the Grand Health Alliance (GHA) against this law. Momentum gathered, bolstered by additional health workers' grievances about lack of PPE, ill treatment by patients and relatives under stringent Covid-19 hospital visiting rules, and mounting fatalities among their cadres. Additional nurses, hired by government in an attempt to manage emergency demand in hospitals, came out in protest in May 2020 when they too began to suffer high infection rates. In December 2020 the government announced the privatisation of the Pakistan Institute of Medical Sciences, and the GHA scaled up its protests into a fully-fledged strike. Government responses varied, from arrests of protesting health workers in Quetta to negotiations over PPE and pay in Lahore and Karachi.

Also mobilised before the pandemic were Pakistan's Lady Health Workers (LHWs). These frontline community health workers, who provide vaccinations, contraception and maternal health screening in rural and peri-urban areas, have formed associations to demand improved employment conditions since 2010 , holding strikes, sit-ins and legal petitions. In October, tired of inadequate PPE, limited health risk allowances and the inability to meet patients' demands due to global supply chain disruptions, thousands of LHWs held a sit-in outside the National Assembly in Islamabad and were joined by the temporary nurses. Government agreed to meet their demands.

Yet another strand of unrest in the health sector during the pandemic is medical students' opposition to changes to their examination structure and licensing system. A legal petition and online activism led to a delay in the medical school admissions exam in November 2020, which then went ahead despite rising Covid-19 infection rates, leading protesters to question its legality and demand a re-test. 


\subsection{Providing and monitoring Covid relief}

One of the primary forms of civic action during the pandemic related to relief work and monitoring of relief funds. Globally, CSOs set about repurposing themselves to do emergency relief work during the pandemic ${ }^{130}$. Some have argued that the pandemic presented a window of opportunity to demand accountability from government ${ }^{131}$. Across our three countries several different civic actors engaged in different forms of civic action to take on crucial relief work during the pandemic.

In Pakistan, several protests were held to demand that the state and coalitions provide relief to those in need. Protests against the lack of services in government hospitals were discussed by our panel, who also noted that due to the shortage of PPE kits NGOs were providing these to doctors. When floods hit Karachi, and residents staged protests demanding better support from authorities, CSOs worked with the state to provide much-needed relief. The state needed NGOs to provide services in the health sector, and our panel discussed how non-profit health organisations were helping the government with vaccine testing facilities and public messaging related to the pandemic. In Nigeria, several coalitions were key to Covid-19 relief. By the end of March, the private sector Coalition Against Covid-19 (CACOVID) had raised over USD 72 million for the purchase of food relief materials and to provide medical facilities and equipment in different regions of the country ${ }^{132}$.

In Nigeria rights organisations like Spaces for Change provided free legal helplines to support victims of Covid-19 lockdown measures. Over 190 Catholic parishes in Lagos donated and distributed palliative items that reached more than 100,000 households ${ }^{133}$. In Mozambique, our panel discussed how several CSOs were involved in the provision of services, such as awareness-raising, distribution of masks, disinfectants and buckets. Many CSOs, since the first moments of the pandemic in the country, were involved in service provision activities, with the status of 'government partners'. These included organisations with a more independent history, and more critical of government. An activist and rights-oriented CSO leader from Sofala Province noted that in the context of the pandemic the government showed more openness to these arrangements, but continuing a trend that they felt was driven by the government's lack of resources, that this was 'taking advantage' of civic organisations, limited to direct service provision, and only as far as organisations 'complied' with government's own aims ${ }^{134}$.

Attempts to hold the government accountable were witnessed in Mozambique and Nigeria. CSOs in Nigeria demanded accountability for Covid-19 funds by writing letters to state governments to publish their spending of these funds received. A CSO, Africa Network for Environment \& Economic Justice (ANEEJ) and MANTRA $A^{i}$ partners began the nationwide monitoring of disbursement of relief money to poor Nigerians ${ }^{135}$. In Mozambique, CSOs were reported to use services as entry points for actions more linked to governance issues, such as the monitoring of schools by a CSO to assess preparedness to reopen schools. Some of these CSOs managed to monitor government action, thus navigating within a civic space marked by major constraints. Additionally, several CSOs also managed to monitor the expenditure of Covid-19 funds through civil society coalitions ${ }^{136}$ (see Box 10). Delays in paying relief payments related to the devasting impacts of Cyclone Idai led thousands of people to gather outside the Sofala Provincial Government's building to demand justice and transparency in the allocation of the funds ${ }^{137}$.

Across all three countries CSOs were involved in providing critical emergency services, often in partnership with the government. Civic actors were also involved in holding the government accountable regarding Covid-19 funds, particularly in Mozambique and Nigeria. Coalitions were critical during emergency relief, both to provide the relief and to hold the government accountable. More 'unruly' tactics such as sit-ins, violent protests, and riots were also visible alongside these partnerships and advocacy efforts. 


\section{Case study: Monitoring Covid-19 relief funds in Mozambique}

Transparency in the use of public funds is a major concern of CSOs in Mozambique, particularly those that work in the area of governance and belong to the Budget Monitoring Forum (Fórum de Monitoria do Orçamento, FMO).

When the Mozambican Government secured significant Covid-19 relief funds from donor governments and the World Bank, the FMO launched the initiative 'Responding to Covid-19 with the right accounts'. The initiative monitors procurement processes and tracks expenses allocated to provinces and districts for works and service provision in various sectors. It also tracks how the Ministry of Health accounts for these funds. The FMO's analysis highlights disbursements by province, rural/urban breakdown and uses of the funds in terms of types of goods and specific institutions. Compiled as reports, the findings are presented to and discussed with government representatives from the relevant ministries.

In a setting where public expenditure lacks transparency, and civil society lacks experience or confidence to confront government, the unusual situation of the pandemic has afforded civil society an unexpected degree of access and voice on the use of Covid-19 relief funds.

\section{Box 11}

\section{Case study: Collaborative Covid-19 relief fundraising in Nigeria}

The pandemic mobilised huge philanthropic funding in Nigeria. Several national and international donors gave funds to the Nigerian Government in support of national efforts to combat the spread of the Covid-19 pandemic. This included USD 114 million from various World Bank sources, intended to contain the Covid-19 outbreak across the 36 states and the Federal Capital Territory. The organised private sector, under the banner of the 112-organisation-strong CACOVID, raised over USD 72 million for relief materials to ameliorate the health crisis and economic hardship triggered by the pandemic. Among other donations received from the religious community, over 190 Catholic parishes in Lagos donated and distributed palliative items that reached more than 100,000 households. Such an influx of charitable donations and aid opened up several new fronts for citizens and CSOs to strengthen their demands for accountability in public expenditure for healthcare and social welfare provisions.

\subsection{Education}

Education was one of the key sites of disruption and contention during Covid-19, against the background of widespread challenges in schools and university access and quality. Issues such as school and university closure and inequalities in remote learning brought forth demands for accountability from civic actors and the general public. Simultaneously students and teachers played a significant role in popular protests during this period. Across our three countries civic actors, both organised civil society and the general public, played a significant role in trying to hold the government accountable for its education policies. In doing so they showed that collective action was possible despite the overall clampdown on civic space, and particularly on issues of suddenly higher priority.

Concerns about student safety and possible transmission of the virus were highlighted by groups in all three countries. Medical students in Pakistan demanded postponement of examinations. In Nigeria, teacher unions warned the government that implementing distancing guidance and other safety measures was infeasible for public schools ${ }^{139}$. In Mozambique, the NGO-led campaign 'Education for All' advocated for school closures until schools were safe for students, pushing the government to issue clear guidelines for the reopening of schools ${ }^{140}$. 
In Balochistan, Pakistan, students protested at how their lack of stable internet connections, in the face of strict internet controls and shutdowns, was impacting their learning as classes moved online ${ }^{141}$. Our panels discussed the 'digital divide' for students during the pandemic as a serious concern, and noted too the gendered implications of school and university closures, with girls facing increasing risk of being expected to do domestic work rather than studying from home.

In Pakistan, civic action around pre-Covid issues such as the right to form student unions, bigger budgets for higher education, and sexual harassment on campuses, persisted during the pandemic, but also incorporated the challenges of studying under Covid-19. The Student Solidarity March in Pakistan in November raised these issues as well as the impact of poor internet provision throughout the country on remote learning ${ }^{142}$. Other issues such as the Federal Government's attempt to institute the Single National Curriculum became major talking points in the media, with discussions on the Islamisation of education. In Nigeria, closure of universities in March 2020 allowed for the high participation of the youth in protests and civic mobilisation. These included student union-led protests around electricity and fuel price hikes ${ }^{143}$, the August \#RevolutionNow demonstrations ${ }^{144}$, and the EndSARS mobilisation. During the latter, the government announced universities would re-open, interpreted by some as attempting to neutralise the protests ${ }^{145}$.

Overall, one common theme across our countries has been the public debate over reopening of schools. Civic action by students and teachers was more visible in Nigeria and Pakistan, whereas Mozambique witnessed a more central role played by CSOs. While both Nigeria and Pakistan demonstrate a confrontational approach to demanding accountability, in Mozambique accountability was sought through gathering and presenting evidence. Online mobilisation was a prominent strategy across countries, and unruly protests, filing legal petitions and media advocacy were also prominently used in this period.

\subsection{Gender-based violence}

Emergencies and crises are known to increase gender-based violence (GBV) ${ }^{146}$. Evidence globally confirms this for the Covid-19 pandemic ${ }^{147}$. Responses and mobilisation from both organised and unorganised civil society emerged on these issues across all three countries in this project.

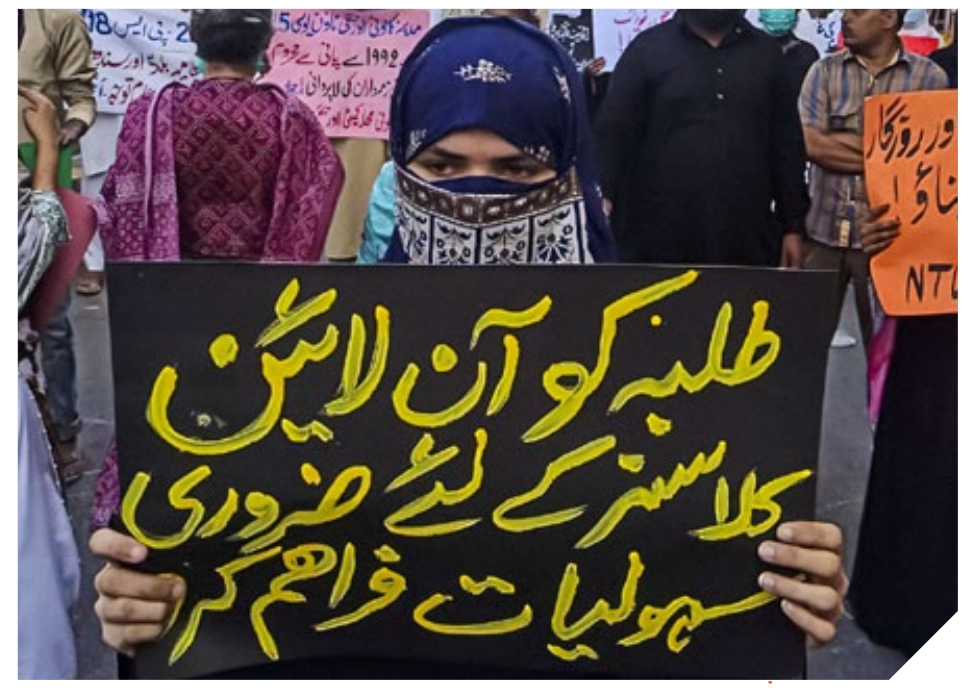

Different forms of civic action were witnessed during the pandemic across the three countries including protests, advocacy, digital activism, direct service provision, coordination with the state and other civil society actors, and filing of petitions. In Nigeria and Pakistan this included physical protests. Pakistan saw protests on the issues of sexual harassment on campuses and at workplaces, sexual assault against women from minority communities, targeted attacks on female journalists, and victim blaming by the police ${ }^{148}$. Nigeria witnessed protests over rising GBV during Covid-19 ${ }^{149}$. The International Federation of Women Lawyers Nigeria, active in this campaign, also offered free legal assistance to victims of GBV, as well as advocating for policy change ${ }^{150}$. In Pakistan, our panel heard how CSOs were setting up helplines and offering shelter to women, in coordination with the provincial government in some cases.

The pandemic also saw increased discussion and public condemnation of GBV both online and offline. In Nigeria, our panel discussed how a high-profile rape case involving a popular singer led to much public condemnation of sexual violence and the complicity of security forces in intimidating victims in such cases. Digital activism powered a large-scale petition calling on the UN to remove the accused from the position of 'Youth Ambassador'151. Mozambique witnessed public condemnation of sexual violence committed by members of the police and security forces ${ }^{152}$. The Mozambique panel explored how in two cases, information on GBV was digitally circulated via social media which led to media discussion of sexual violence in Mozambique, and impunity of perpetrators more generally.
ABOVE

A young woman in Pakistan protesting during the pandemic, with a sign that reads 'Provide students with adequate resources for online classes'. PHOTO: KHIZER HABIB 
Civic action also took the form of lobbying for better policies on GBV in Nigeria and Pakistan, continuing pressure on issues under debate for some time. In Nigeria, after significant civil society and activist pressure, a Sexual Harassment Bill was passed in July 2020 focusing on universities and tertiary institutions ${ }^{153}$. Our panel described this as a piece of 'landmark' legislation and a great win for civil society activists, although also noting the need to maintain pressure on state-level adoption of other relevant legislation. Two ordinances concerning sexual violence were passed in the Pakistani parliament which banned the controversial 'two-finger test' ${ }^{\prime} 154$. Students in Pakistan continued to demand the inclusion of students in sexual harassment committees, and Pakistani journalists and feminists wrote a public letter to 'The State of Pakistan' condemning GBV in the country and vicious online attacks on prominent female journalists, and making a charter of demands involving provisions for women's safety ${ }^{155}$.

Across all three countries GBV was observed to have increased and become a part of public debates on the effects of the pandemic. State actors were observed to perpetrate GBV in all three countries. In Mozambique, state actors were direct perpetrators of sexual violence, in Nigeria they were complicit in protecting the accused and harassing victims further, and in Pakistan they blamed the victim for the crime. Civil society, both formal CSOs and general public, protested, engaged in media debates, and pressurised the state and international bodies to demand change.

\subsection{Economic issues and livelihoods}

The economic impact of the pandemic was significant in all three countries. Immediate restrictions on businesses and trading were followed as the pandemic wore on, with escalating concerns about livelihoods, unemployment and the costs of basic goods, all of which triggered new action and demands from civic organisations. Those reliant on the informal economy were particularly vulnerable, and the inability of social security and social protection systems to cushion the economic fall-out was laid bare in many countries ${ }^{156157}$. Consequently, the pandemic led to several forms of civic action led by unions, professional associations, and unique coalitions that sought to address issues concerning the economy and livelihoods.

Pakistan saw a variety of civic action related to livelihoods, as incomes fell and economic pressure mounted. Workers from unions and federations held protests and approached the court to address
BELOW

Members of the Pakistan Fisherfolk Forum hold a protest at sea in September 2020 against government plans that threatened their livelihoods. PHOTO: KHIZER HABIB

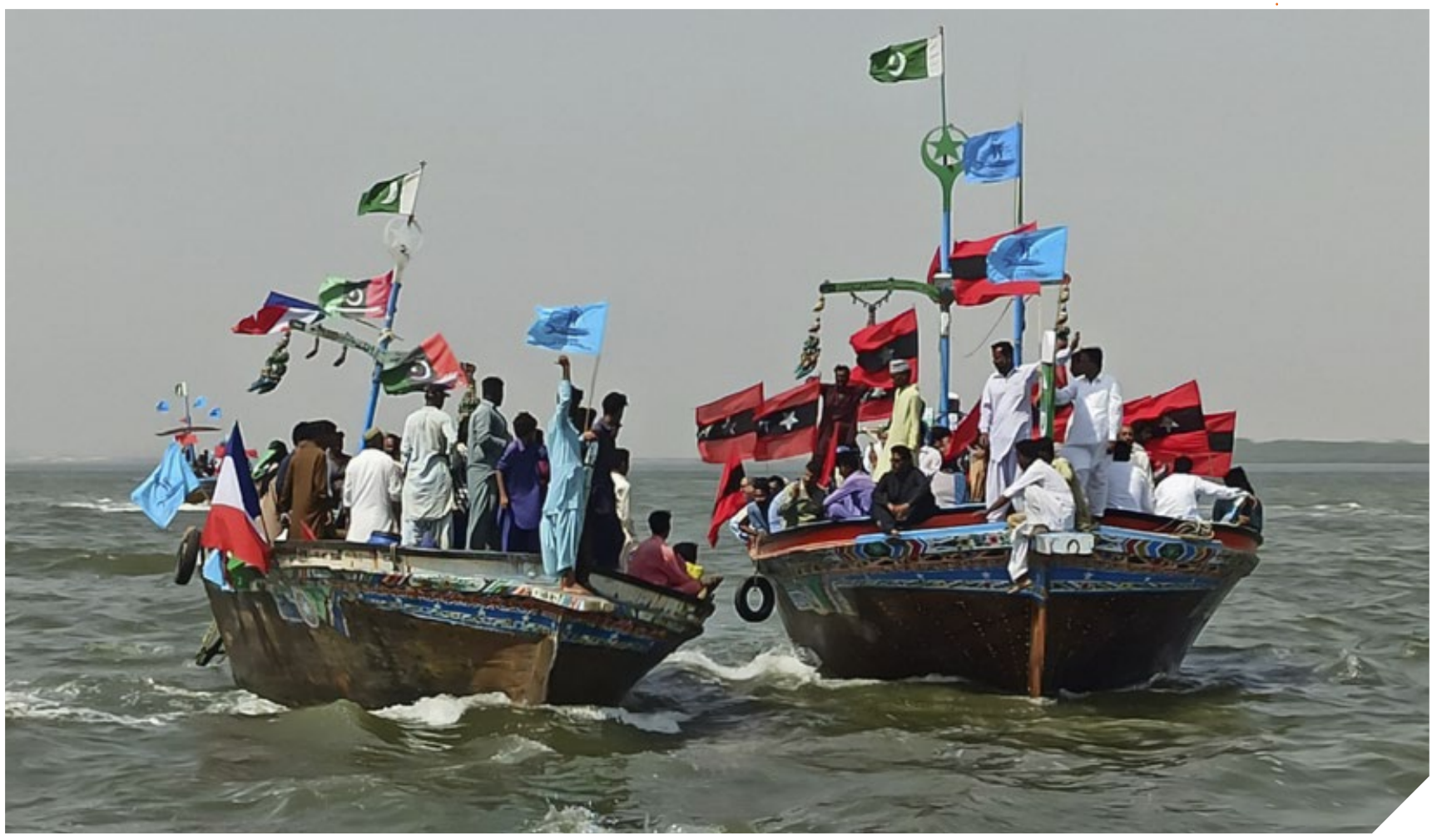

'The 'two finger test' is a form of virginity test used in several countries for multiple reasons which has been discredited for being a medically unnecessary, and at times painful and traumatic practice. 
issues such as privatisation policies, closure of factories, low prices, and increased layoffs among other issues. The Pakistan Fisherfolk Forum (PFF), a CSO representing the fishing community in coastal areas of Pakistan, began to mobilise in September against plans to develop two islands off the coast of Karachi and the Federal Government's decision to provide licenses to deep-sea fishing trawlers, reducing their own income ${ }^{158}$. Seven hundred employees of Radio Pakistan staged a mass sit-in against their recent sacking which received a good measure of political response, although they have not yet been restored ${ }^{159}$. Hundreds of brick kiln workers staged a protest after closures of brick kilns ${ }^{160}$, and bread-makers in Balochistan went on strike for days in November demanding better fixed prices ${ }^{161}$. Worker's groups often acted in solidarity, such as in the case of unions supporting farmers demanding lower tariffs on electricity ${ }^{162}$, and the collective protests of trade unions and the federation of home-based workers ${ }^{163}$.

In Nigeria unions were active. Interest groups actively represented disparate sectors of the workforce while protesting job and income loss. Our panel reflected that adopting the 'leaderless' approach taken by other mobilisations was connected to common disappointment following previous mass actions initiated by trade unions, human rights organisations and CSOs, and a loss of public trust that these formally organised protests would lead to change. Weeks before the leaderless EndSARS protests, the leadership of the Nigerian Labour Congress (NLC) and the Trade Union Congress (TUC) suspended a planned general strike against hikes in electricity tariffs and fuel prices ${ }^{164}$.

There were instances of civic action around prices of goods and services in Pakistan and Nigeria. In Pakistan, farmer's demands are rarely covered by urban-based media, so in November farmers belonging to Kissan Ittehad (KI) and the Pakistan's Farmer's Board marched to Lahore to demand a uniform tariff rate for electricity to run tube-wells, an increase in the government's purchase rate of wheat and sugarcane, and a price reduction of fertilisers and pesticides in all provinces ${ }^{165}$. Women rallied demanding an end to price hikes, joblessness, and the plans for commercial development of Sindh islands ${ }^{166}$. In Nigeria, members of political associations like the Socialist Party of Nigeria (SPN) and the National Conscience Party (NCP), and students from the National Association of Nigerian Students (NANS)

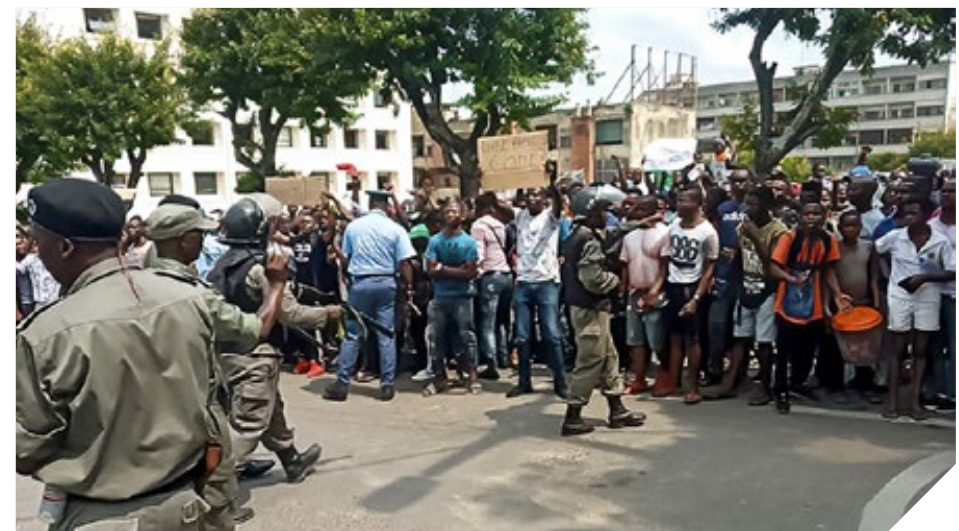

were involved in organising demonstrations against the increase in petrol prices and electricity tariff. Additionally, the problem of food insecurity led to food riots in several parts of the country. Thousands broke into warehouses used to store allegedly hoarded Covid-19 relief goods, amid claims of state corruption ${ }^{167}$

Mozambique witnessed civic action in the form of advocacy and media debates. The Confederation of Economic Association, a business lobby, pressured the government to protect lives of workers ${ }^{168}$. An example of public debate covered by the media, involving several civic groups, and discussed by our panel was about the nature and scope of a proposed Sovereign Fund that could create savings from Mozambique's anticipated gas revenues and reduce the country's dependence on foreign aid as well as promote its development based on the resources at its disposal. Even though the lives and livelihoods of those working in small and medium enterprises were affected by the pandemic, our panel didn't observe any significant social movement led by trade unions or CSOs around the issue, with action focusing instead on humanitarian assistance and poverty relief alongside fundraising for personal
66 Activism is no longer the exclusive reserve of civil society, trade unions and media advocates, but a wider group of private actors and associational bodies campaigning extensively online and offline against various social issues, injustices and restrictions, including demanding better welfare for their members. 99

\section{- NIGERIA RESEARCH TEAM} protective equipment.

Overall, in all three countries civic action around the economy, livelihoods, and costs of goods and services were prominent. We observed several protests in Pakistan led by unions and professional
ABOVE Maputo protest March 2020. HOTO: ROMEU DA SILVA, DW.COM 
associations, interest groups in Nigeria, and professional associations and CSOs in Mozambique. Unruly protests, sit-ins, advocacy and media debates were some of the repertoires used in these countries. While these repertoires are not new in any of these countries, their use seems to have increased in frequency and intensity in a period of great economic upheaval and dramatic livelihoods impacts.

\subsection{Policing and law and order}

The heavy-handed and securitised response to the pandemic brought to crisis point a range of longheld grievances about the insecurity facing people in their everyday lives, and the role of state actors in sustaining or causing that insecurity ${ }^{169}$. Around the world this manifested in a range of action, including protests against lockdown and public health measures. In all three of our countries, it created grounds for flashpoints in relation to law and order and the actions of security services.

In Mozambique businesspeople in Beira staged a three-day strike in October in protest at the state's inaction or inability to address a wave of kidnappings that also affected the capital, Maputo. Following a press conference by small business leaders others joined the strike, reportedly 'paralysing' the market and trading activity in Mozambique's second-largest city ${ }^{170}$. Following government threats to fine those that closed their businesses, civic, religious, and political leaders, including the opposition-party Mayor of Beira City, added their voices to campaign against insecurity. In Pakistan protests and campaigning against insecurity focused particularly on the issue of forced disappearances and arbitrary arrests of government critics and dissenting voices. Multiple online campaigns were spurred, often successfully, to free prominent arrested journalists and commentators ${ }^{171}$. In August, families of missing persons from Balochistan staged a sit-in outside the Press Club in Quetta ${ }^{172}$, continuing many years of peaceful protests against abductions which have included long marches and hunger strikes. Similar sit-in tactics were used in a rare protest by the group of women in North Waziristan whose male family members had disappeared ${ }^{173}$.

In Nigeria demonstrators gathered across the country in August to protest under the hashtag banner \#RevolutionNow, calling for authorities to take accountability for rising insecurity and poor governance ${ }^{174}$. Attacks on and arrests of the protestors by state security forces were justified by the police on public health grounds ${ }^{175}$. These dynamics reappeared a few months later in October, as protests erupted at the latest actions of the Special Anti-Robbery Squad (SARS), under the hashtag banner \#EndSARS (see Box 12) and tapping into widespread anger at police brutality and overpolicing ${ }^{176}$. The Nigerian observatory panel and researchers noted various ways that the pandemic context heightened the power of this moment and movement.

\section{Box 12}

\section{Case study: \#EndSARS protests}

The campaign to abolish the Nigerian Special AntiRobbery Squad (SARS) first gained prominence in online and offline protests in 2018, opposing the particular brutality and targeting of young people by this police unit. But against a background of brutal enforcement of lockdown measures and growing insecurity and vulnerability, the October 2020 protests spurred a significant change in direction in Nigerian activism. On 1 October 2020, activists mobilised in small demonstrations across the country to protest against insecurity and poor governance on Nigerian Independence Day. A few days later footage of SARS killing of a young man in Delta State started circulating online, leading to nationwide protests on 8 October. Organised largely online, outside of formal organisations, and mostly by young people, the protests also gained widespread support from businesses, celebrities, and religious organisations. Unlike other protests and demonstrations in recent Nigerian history, the leaderless structure of the movement, solidarity of activists, and crowd-funded nature of the action resisted attempts at co-optation by authorities, and saw a resurgence in mutual aid and community organising. The violent and deadly crackdown on protests and attempts to use Covid-19 restrictions to ban them only fuelled the dissent and activism. 


\subsection{For civic space: 'No space to breathe ${ }^{\mathrm{k}}$}

The Governments of Mozambique, Nigeria and Pakistan have each been particularly swift and far-reaching in rolling back democratic progress by squeezing an already-constrained civic space still further during the pandemic. Here and in a wide range of other countries, power seems likely to become more centralised and less shared, and civic space more constricted in years to come. The evidence suggests that the governments of these three countries are using the Covid-19 crisis juncture opportunistically to advance preexisting anti-democratic projects of stifling dissent and manufacturing consent, not only applying temporary measures to protect public health. Covid-19 relief partnerships between government and CSOs, reflecting opportunism on both sides, are likely to be short-lived, small air bubbles in a context where there is less and less room for civil society to breathe.

For the foreseeable future, then, as V-DEM captured in the title of its latest democracy report, autocratisation looks set to remain viral ${ }^{178}$. Civic space in these three countries seems likely to be increasingly affected by a process of concentration of power, in which aspects of decentralised systems are re-centralised and sub-national autonomies clawed back. This cannot be interpreted as a simple reversal of locally empowering democratic decentralisation: these are contexts where governance has been fragile throughout their post-colonial histories and decentralisation processes never decidedly democratic, nor always intended to empower local levels, nor particularly effective at resolving historical sub-national grievances.

Nonetheless, the marked centralising turn that we have observed in Mozambique, Nigeria and Pakistan during the pandemic has serious ongoing implications for civic space. In these contexts of fragile political pluralism, civic space at national and sub-national levels has been a crucial arena for critical dialogue, expression of difference, and pluralism. The centralisation and concentration of power tends to increase political, ethnic and religious inequality and strife at the same time that spaces for managing differences peacefully and democratically are coming under rising pressure and the economic effects of the pandemic are increasing competition for resources. It jeopardises the balance of powers, as the executive takes and retains a disproportionate degree of authority and wields it heavy-handedly through the security forces under its command. It favours the securitisation of governance, to the neglect of other dimensions of the social contract and to the benefit of state or dominant party schemes to close and control civic space. Our Mozambique researcher's observation that 'when civic space closes, violence rises ${ }^{\prime 179}$ may capture a correlation rather than a causal relationship, but it is a correlation to be heeded.

\subsection{For citizen-state relations: Prolonged post-pandemic polarisation}

While the Covid-19 pandemic has been the first of its kind since the influenza pandemic of 1918, it is acknowledged to herald a more uncertain future, in which pandemics join terrorist and nuclear threats as occurrences that can never be ruled out ${ }^{180}$. Viewed thus, what we have seen in 2020 s-21 is only the beginning of an enduring securitisation of public health and democratic governance, in which civil society and government are re-positioned antagonistically with one protecting civil liberties and the other a securitised version of public health and the common good.

Governments need civil society, whether they like it or not, even if they actively dislike its more vocally critical elements ${ }^{181}$. If this is true in ordinary times, it has proven more true in these times of Covid, when civil society has been a vital ally for targeting relief and delivering health prevention messages, and a useful if unwelcome barometer of public opinion on both legitimate government restrictions and security force overreach alike. Since the start of the pandemic emergency in Mozambique, Nigeria, and Pakistan, both parties to the governance relationship have been looking more askance at each other than before, homing in on each other's perceived weak flanks under increased pressures of all kinds including, crucially, on public finances and aid flows. In this latest episode of an ongoing distancing and withdrawal of trust, the default mode has been one of suspicion.

\footnotetext{
${ }^{\mathrm{k}}$ The phrase is borrowed from a Pakistan observatory panel member.
} 
Following in the footsteps of repressive states elsewhere that have developed sophisticated repertoires of social and judicial harassment of activists $^{182}$, elements within these three countries' states are set to continue 'oppositionising' the more contestatory segments of civil society, driving it into the arms of the political opposition and possibly even armed insurgent opposition in some instances. As authoritarian and autocratisation patterns deepen, civil society actors, turned into victims of acute human rights abuses, are becoming more explicitly anti-government in their narrative and consolidating adversarial and denunciatory identities, as seen in practices like honouring as martyrs the individuals most acutely persecuted by the state.

In settings of acutely polarised government-civil society relations, collapse of the rule of law and direct oppression of civil society, bilateral official and non-governmental aid has been able to play an important role when it has been politically savvy, adaptive and risk-taking ${ }^{183}$. Often this has involved suspension of governmentto-government aid, with non-governmental international solidarity channels coming to the fore instead, as well as more deliberate and visible alignment of donor countries' aid operations with their diplomatic operations. There is a history of the United Nations system playing a central role in such polarised settings, particularly through the Office of the High Commissioner for Human Rights and its Special Rapporteurs on key civic freedoms and acute forms of rights violations ${ }^{184}$. The challenge to official aid donors operating in Mozambique, Nigeria and Pakistan and similar contexts today is to both adapt their own bilateral roles to the evolving dynamics of civic space, and to act in concert to bolster the legitimacy, reach and effectiveness of the multilateral UN human rights system.

\subsection{For civil society and civic action: Weathering, circumventing or countering the constraints}

Despite the evidence of newfound coalitions and solidarity especially early in the pandemic, the fractures showing up in civil society in all three countries look likely to widen. Fragmentation will be driven by growing competition between CSOs for dwindling external and government funding and for favour with the state, and by mounting

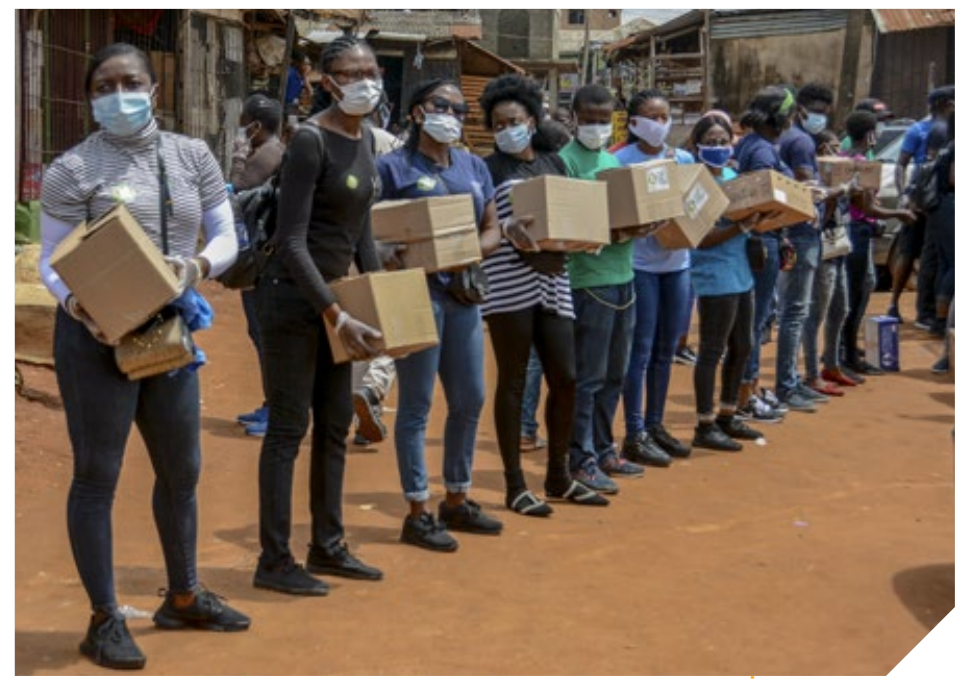

pressure towards welfare and relief work and away from advocacy. Civil society in Mozambique, Nigeria and Pakistan may see the emergence of small but stronger and more significant contentious segments than have existed before, even while other CSOs retreat from advocacy into uncontroversial service provision roles.

The increasingly sophisticated, targeted and overt fake news strategies deployed by these and other governments are likely to continue limiting, monitoring, stigmatising and discrediting both civic space as an arena and civil society actors themselves. The shift of civic activism online will continue to be an empowering trend. But a key question will be how fast and how far the shifts online of activism are mirrored by shifts online of surveillance, harassment, delegitimisation and sabotage, and how well activists succeed in shielding themselves against its worst effects, exposing it and campaigning for online privacy and safety. Another question is to what extent the online activism initially spawned by crisis can evolve in the longer term into sustained movements for change, online, offline or combined.

More positively, civic action has found fresh impetus through this crisis. The pandemic and the injustices it laid bare have had a political consciousness-raising effect, igniting existing campaigners, protesters and accountability claimants and enlisting new recruits into activist expressions of critique and moral outrage. Some of these expressions relate to pandemic-induced privations and abuses committed under cover of the pandemic. Others are defences of civic space itself, asserting the role of civil society in holding
ABOVE

Volunteers at the Lagos Food Bank Initiative outreach to Ikotun, Lagos, Nigeria, June 7, 2020.

PHOTO: OLUWAFEMI DAWODU, SHUTTERSTOCK.COM 
governments to account, and some model nonhierarchical and democratic practices and cultures within that space.

Also positively, the new focus on monitoring Covid-19 relief to try to ensure fair distribution and transparent, accountable management testifies to new levels of indignation at the violation of the 'moral economy' that underpins popular expectations of how public provision should work $^{185}$. This may well translate longer-term into more homegrown citizen oversight and advocacy on normal public expenditure as well as emergency relief. While the leadership roles assumed in some Covid-19 emergency contexts by celebrities and social influencers may prove to be fleeting, the coalitions emerging around shared occupational, demographic or political identities are likely to endure, deepen and perhaps even become crossclass alliances as the longer-lasting effects of the pandemic and policy and budget responses are felt on livelihoods and lifestyles. No less will be needed, to hold open a further-shrinking civic space.

The navigation strategies of civil society actors in these changing civic spaces are likely to settle down and become more distinct with time. Should they build on service delivery relationships forged with government in crisis? Should they get behind and amplify popular politics and civic indignation? While most CSOs will probably adopt a mixed strategy for pragmatic reasons, many will be forced to hone their political identities more definitively than before. Civil society may well segment into actors that weather civil-society-restricting moves, those that circumvent them, and those that actively counter them - and the latter will need to work more centrally on movement-building, organising and coalition strategies in order to survive and thrive in the civic space of the future.

\subsection{Conclusion}

The shifts in citizen-state relations we have seen intensify during the pandemic call for re-strategising, re-positioning and re-tooling by advocates of democracy and accountable governance at all levels. Activists and civic organisations will have difficult choices to make, and need to chart a careful path to maintain solidarity across causes and identities. International actors, including aid donors, need to revive approaches used in the least democratic settings and in less democratic global eras. In contexts where civil society, civic space and government notions of accountability have been heavily shaped by international aid, the defence of civic space and assertion of accountability claims over the past year by domestic social actors - not dominated by donors or international NGOs - hold particular promise. The energy generated to monitor civic freedoms and call out the democratic backsliding we have seen during the pandemic must be sustained, and both national and international attention focused on the dangers of emergence from the pandemic with our civil liberties eroded and autocratic governance normalised. 


\section{References}

${ }^{1}$ Sarah Repucci, 'Freedom in the World 2020: A Leaderless Struggle for Democracy' (Freedom House, 2020), https://freedomhouse.org/report/ freedom-world/2020/leaderless-struggle-democracy.

${ }^{2}$ Elisha Aaron, 'Coronavirus Shows the Need for a Human Rights-Based Approach to Public Health Crises', Freedom House (blog), 3 August 2020, https://freedomhouse.org/article/coronavirus-shows-need-humanrights-based-approach-public-health-crises.

${ }^{3}$ Ayesha Khan, Aslam Khwaja, and Asiya Jawed, 'Navigating Civic Spaces During a Pandemic Pakistan Report' (Collective for Social Science Research, December 2020), opendocs.ids.ac.uk/opendocs/ handle/20.500.12413/16543; Spaces for Change, 'Navigating Civic Space in a Time of Covid: Nigeria Country Report' (Lagos: Spaces for Change, January 2021), opendocs.ids.ac.uk/opendocs/ handle/20.500.12413/16565; Crescêncio Pereira and Salvador Forquilha, 'Navigating Civic Space in a Time of COVID-19: Mozambique Country Report' (Maputo: Institute for Social and Economic Studies, January 2021), opendocs.ids.ac.uk/opendocs/handle/20.500.12413/16570.

${ }^{4}$ CIVICUS, 'People Power Under Attack' (CIVICUS, December 2019), 5, https://civicus.contentfiles.net/media/assets/file/ GlobalReport2019.pdf.

${ }^{5}$ Repucci, 'Freedom in the World 2020: A Leaderless Struggle for Democracy', 1.

${ }^{6}$ Nazifa Alizada et al., 'Autocratization Turns Viral' (University of Gothenburg: V-Dem Institute, March 2021), 9, https://www.v-dem.net/ media/filer_public/c9/3f/c93f8e74-a3fd-4bac-adfd-ee2cfbc0a375/ dr_2021.pdf.

${ }^{7}$ Anna Lührmann, Marcus Tannenberg, and Staffan I Lindberg, 'Regimes of the World (RoW): Opening New Avenues for the Comparative Study of Political Regimes', Politics and Governance 6, no. 1 (2018): 18.

${ }^{8}$ Charles Tilly and Sidney G. Tarrow, Contentious Politics, Second revised edition (New York, NY: Oxford University Press, 2015), 75

${ }^{9}$ Naomi Hossain and Nalini Khurana, 'Donor Responses and Tools for Responding to Shrinking Space for Civil Society: A Desk Study' (Swiss Agency for Development and Cooperation (SDC), 2019), 6, https:// opendocs.ids.ac.uk/opendocs/handle/20.500.12413/15118.

${ }^{10}$ United Nations, 'United Nations Guidance Note: Protection and Promotion of Civic Space' (United Nations, September 2020), https://www.ohchr.org/Documents/Issues/CivicSpace/UN Guidance_Note.pdf.

11 'Development Needs Society-The Implications of Civic Space for the Sustainable Development Goals', ACT Alliance Development, 1 April 2019, https://opendocs.ids.ac.uk/opendocs/handle/20.500.12413/14541.

${ }^{12}$ Claudia Hacke and Antoine Buyse, 'Research Bibliography Civic Space and Human Rights 10 and NGO Sources 2015 to 2020' (Utrecht University, January 2021), https://documentcloud.adobe.com/link/trac k?uri=urn:aaid:scds:US:ae551b2a-e167-4275-b302-d0f1caf65da1.

${ }^{13}$ Hossain et al., 'Development Needs Society-The Implications of Civic Space for the Sustainable Development Goals'.

${ }^{14}$ Chris van der Borgh and Carolijn Terwindt, 'Shrinking Operational Space of NGOs - a Framework of Analysis', Development in Practice 22, no. 8 (1 November 2012): 1065-81, https://doi.org/10.1080/09614524 .2012 .714745 .

${ }^{15}$ Antoine Buyse, 'Squeezing Civic Space: Restrictions on Civil Society Organizations and the Linkages with Human Rights', The International Journal of Human Rights 22, no. 8 (14 September 2018): 971, https:// doi.org/10.1080/13642987.2018.1492916.
${ }^{16}$ Seraphine F. Maerz et al., 'State of the World 2019: Autocratization Surges - Resistance Grows', Democratization 27, no. 6 (17 August 2020) 909-27, https://doi.org/10.1080/13510347.2020.1758670.

${ }^{17}$ Fiona Garguilo, '2019: A Year of Protest', IPI Global Observatory (blog), 20 December 2019, https://theglobalobservatory.org/2019/12/a-yearof-protest/.

${ }^{18}$ Samuel J. Brannen, Christian S. Haig, and Katherine Schmidt, 'The Age of Mass Protests: Understanding an Escalting Global Trend' (Centre for Strategic \& International Studies, March 2020), 1, https://csis-website-prod. s3.amazonaws.com/s3fs-public/publication/200303_MassProtests_V2.pdf.

${ }^{19}$ Erica Chenoweth, 'The Future of Nonviolent Resistance', Journal of Democracy 31, no. 3 (July 2020): 69-84.

${ }^{20}$ Richard Youngs, Civic Activism Unleashed: New Hope Or False Dawn for Democracy? (Oxford University Press, 2019).

${ }^{21}$ Carnegie Endowment for International Peace, 'Global Protest Tracker - Carnegie Endowment for International Peace', 31 March 2021, https:// carnegieendowment.org/publications/interactive/protest-tracker.

${ }^{22}$ Einar Braathen, Camilla Houeland, and Berit Aasen, 'Civil Society under Pressure' (NORAD, 2018), 19, https://norad.no/en/toolspublications/ publications/2018/civil-society-under-pressure/.

${ }^{23}$ Ahmed El Assal and Amr Marzouk, 'Reinvention of Nationalism and the Moral Panic against Foreign Aid in Egypt', in The Power of Civil Society in the Middle East and North Africa: Peace-Building, Change, and Development, ed. Ibrahim Natil, Chiara Pierobon, and Lilian Tauber, 1st ed. (Abingdon, Oxon ; New York, NY : Routledge, 2019. | Series: Routledge explorations in development studies: Routledge, 2019), https://doi.org/10.4324/9780429265006.

${ }^{24}$ This list draws on: Buyse, 'Squeezing Civic Space'; Borgh and Terwindt, 'Shrinking Operational Space of NGOs - a Framework of Analysis'; Naomi Hossain et al., 'What Does Closing Civic Space Mean for Development? A Literature Review and Proposed Conceptual Framework', IDS Working Papers, no. 515 (31 July 2018), https://opendocs.ids.ac.uk/opendocs/ handle/20.500.12413/13962; Saskia Brechenmacher and Thomas Carothers, 'Defending Civic Space: Is the International Community Stuck?', Carnegie Endowment for International Peace, 29 October 2019, 45.

25 Thomas Carothers and David Wong, 'Authoritarian Weaknesses and the Pandemic', Carnegie Endowment for International Peace, August 2020, https://carnegieendowment.org/2020/08/11/authoritarianweaknesses-and-pandemic-pub-82452; Elena Danescu, 'Autocratization Surges-Resistance Grows - Democracy Report 2020' (Gothenburg, Sweden: V-Dem Institute, the Department of Political Science at the University of ..., March 2020), https://www.v-dem.net/en/publications/ democracy-reports/; Amanda B Edgell et al., 'An Update on Pandemic Backsliding: Democracy Four Months After the Beginning of the Covid-19 Pandemic' (V-Dem Institute, the Department of Political Science at the University of ..., 30 June 2020), https://www.v-dem.net/en/ourwork/research-projects/pandemic-backsliding/; Sarah Repucci and Amy Slipowitz, 'Freedom in the World 2021: Democracy Under Siege' (Freedom House, 2021), https://freedomhouse.org/sites/default/ files/2021-02/FIW2021_World_02252021_FINAL-web-upload.pdf; Palina Kolvani et al., 'Pandemic Backsliding: Democracy and Disinformation Seven Months into the Covid-19 Pandemic' (V-Dem Institute, the Department of Political Science at the University of ..., October 2020), https://www.v-dem.net/media/filer_public/37/de/37defb66-94574eeb-887a-f0c168dc4365/v-dem_policybrief-25_201002_v2.pdf; Nazifa Alizada et al., 'Autocratization Turns Viral'; Anwar Mhajne Whetstone Crystal, 'The Rise of the COVID Dictatorships', Foreign Policy (blog), 16 October 2020, https://foreignpolicy.com/2020/10/16/the-rise-of-thecovid-dictatorships/. 
${ }^{26}$ CIVICUS, 'People Power Under Attack 2020' (CIVICUS, 8 November 2020), https://civicus.contentfiles.net/media/assets/file/

GlobalReport2020.pdf; ICNL, 'Top Trends in COVID Impact on Civic Space.Pdf' (International Center for Not-for-Profit Law, May 2020), https://www.icnl.org/wp-content/uploads/05.2020-Trends-in-COVIDimpact-on-CS-vf.pdf.

${ }^{27}$ Cheeseman and Jeffrey Smith, 'Authoritarians Are Exploiting the Coronavirus. Democracies Must Not Follow Suit.', Foreign Policy, 28 April 2020, https://foreignpolicy.com/2020/04/28/authoritarians-exploitingcoronavirus-undermine-civil-liberties-democracies/; Kanishka Jayasuriya, 'The Rise of the Right: Populism and Authoritarianism in Southeast Asian Politics', Southeast Asian Affairs 2020, no. 1 (13 May 2020): 43-55; Kolvani et al., 'Pandemic Backsliding: Democracy and Disinformation Seven Months into the Covid-19 Pandemic'; Nazifa Alizada et al., 'Autocratization Turns Viral'; Sarah Repucci and Amy Slipowitz, 'Freedom in the World 2021: Democracy Under Siege'.

${ }^{28}$ Nazifa Alizada et al., 'Autocratization Turns Viral'.

${ }^{29}$ Felix S. Bethke and Jonas Wolff, 'COVID-19 and Shrinking Civic Spaces: Patterns and Consequences', Zeitschrift Für Friedens- Und Konfliktforschung, 2 October 2020, 1-12, https://doi.org/10.1007/ s42597-020-00038-w; CIVICUS, 'People Power Under Attack 2020'.

${ }^{30}$ Forum on Information and Democracy, 'Working Group on Infodemics' (Forum on Information and Democracy, November 2020), https:// informationdemocracy.org/wp-content/uploads/2020/11/ForumID_ Report-on-infodemics_101120.pdf.

${ }^{31} \mathrm{~J}$ Scott Brennen et al., 'Types, Sources, and Claims of COVID-19 Misinformation', April 2020, 13; Kolvani et al., 'Pandemic Backsliding: Democracy and Disinformation Seven Months into the Covid-19 Pandemic'.

${ }^{32}$ CIVICUS, 'People Power Under Attack 2020'; CIVICUS, 'Civic Freedoms and the Covid-19 Pandemic', Research Brief (Civicus, April 2020), https:// monitor.civicus.org/COVID19/.

${ }^{33}$ CIVICUS, 'People Power Under Attack 2020'; Nazifa Alizada et al., 'Autocratization Turns Viral'.

${ }^{34}$ Adrian Shahbaz and Allie Funk, 'Freedom on the Net 2020: The Pandemic's Digital Shadow' (Freedom House, October 2020), https:// freedomhouse.org/sites/default/files/2020-10/10122020_FOTN2020 Complete_Report_FINAL.pdf; Marisa von Bülow, 'The Impacts of the Pandemic on Digital Activism' (Resocie, 17 November 2020), https:// resocie.org/wp-content/uploads/2020/11/ResearchReport02_resocievon-Bulow.pdf; Steven Feldstein and Steven Feldstein, 'Revitalizing Democracy: Digital Democracy Struggles - The Day After', Carnegie Endowment for International Peace (blog), accessed 6 October 2020, https://carnegieendowment.org/2020/09/09/digital-democracystruggles-pub-82532.

${ }^{35}$ Tony Roberts et al., 'Digital Rights in Closing Civic Space: Lessons from Ten African Countries', 26 February 2021, https://doi.org/10.19088/ IDS.2021.003.

${ }^{36}$ Adrian Shahbaz and Allie Funk, 'Freedom on the Net 2020: The Pandemic's Digital Shadow'; CIVICUS, 'People Power Under Attack 2020'.

${ }^{37}$ Duncan Green, 'How Is Covid-19 Affecting Civil Society Worldwide? How Is It Responding?', From Poverty to Power (blog), 23 April 2020, https://oxfamblogs.org/fp2p/how-is-covid-affecting-civilsociety-worldwide-how-is-it-responding/; Niranjan J. Nampoothiri and Filippo Artuso, 'What Can We Learn from 200 Case Studies of "Emergent Agency in a Time of Covid"?', From Poverty to Power (blog), 17 March 2021, https://oxfamblogs.org/fp2p/what-can-we-learnfrom-200-case-studies-of-emergent-agency-in-a-time-of-covid/; Richard Youngs, ed., Global Civil Society in the Shadow of Coronavirus (Carnegie Endowment for International Peace, 2020), https:// carnegieendowment.org/files/Youngs-Coronavirus_Civil_Society final.pdf.
${ }^{38}$ Francesca Angiolillo, 'Pandemic in Brazil: Every Night We Take to Our Balconies in Protest', Literary Hub (blog), 1 April 2020, https:// lithub.com/pandemic-in-brazil-every-night-we-take-to-our-balconiesin-protest/; Yunus Berndt, 'Peopleless Protest: Bridging the OnlineOffline Divide for Greater Movement Impact in the Covid-19 Period', ICNC (blog), 26 August 2020, https://www.nonviolent-conflict.org/ blog_post/peopleless-protest-bridging-the-online-offline-dividefor-greater-movement-impact-in-the-covid-19-period/; Mfuneko Toyana, 'Hashtags and Spectacles: Zimbabwe's Feminist Activists Find Online Avenues to Tackle Government's COVID-19 Clampdown', n.d., https://www.africaportal.org/publications/hashtags-andspectacles-zimbabwes-feminist-activists-find-online-avenues-tac kle-governments-covid-19-clampdown/; Bülow, 'The Impacts of the Pandemic on Digital Activism'; Claudia Ciobanu, 'Poles Find Creative Ways to Protest Despite the Pandemic', Balkan Insight, 21 April 2020, https://balkaninsight.com/2020/04/21/poles-find-creative-ways-toprotest-despite-the-pandemic/; Maciej Kowalewski, 'Street Protests in Times of COVID-19: Adjusting Tactics and Marching "as Usual"', Social Movement Studies, 3 November 2020, https://doi.org/10.1080/147 42837.2020.1843014; Richard Youngs, 'Coronavirus as a Catalyst for Global Civil Society' (Carnegie Europe, 2020), https://carnegieeurope. eu/2020/12/07/coronavirus-as-catalyst-for-global-civil-societypub-83138.

${ }^{39}$ Danescu, 'Autocratization Surges-Resistance Grows - Democracy Report 2020'.

40 The Economist Intelligence Unit, 'Democracy Index 2020: In Sickness and in Health' (The Economist Intelligence Unit, 2021), https://pages. eiu.com/rs/753-RIQ-438/images/democracy-index-2020.pdf.

${ }^{41}$ CIVICUS, 'People Power Under Attack'; CIVICUS, 'People Power Under Attack 2020'.

${ }^{42}$ Except where otherwise stated, the rest of this section is based on the following baseline research reports produced for this project: Ayesha Khan, 'Navigating Civic Space Baseline Report - Pakistan' (Karachi: Collective for Social Science Research, September 2020), opendocs. ids.ac.uk/opendocs/handle/20.500.12413/15788; Crescêncio Pereira and Salvador Forquilha, 'Navigating Civic Space Baseline Report - Mozambique' (Maputo: Institute for Social and Economic Studies, September 2020); Ibezim-Ohaeri, Victoria and Zikora Ibeh, 'The Civic Space in Nigeria: Before and Beyond Covid-19 Baseline Report' (Spaces for Change, 2020), opendocs.ids.ac.uk/opendocs/ handle/20.500.12413/16564.

${ }^{43}$ OECD, 'States of Fragility 2020' (Organisation of Economic Cooperation and Development, September 2020), https://doi.org/10.1787/ fa5a6770-en.

${ }^{44}$ Transparency International, 'Corruption Perceptions Index 2020', accessed 15 April 2021, https://www.transparency.org/en/cpi/2020.

45 USAID, 'The 2016 CSO Sustainability Index for Sub-Saharan Africa' (USAID, 2016), 176, https://www.usaid.gov/africa-civil-society/2016.

${ }^{46}$ Salewa Akomolafe, 'Solidarity with End SARS Protestors', Institute of Development Studies (blog), 22 October 2020, https://www.ids.ac.uk/ news/solidarity-with-end-sars-protestors/.

${ }^{47}$ Daniel Kaufmann and Aart Kraay, 'World Governance Indicators' (World Bank Group, 2020), https://info.worldbank.org/governance/wgi/.

${ }^{48}$ Human Rights Commission of Pakistan, 'State of Human Rights in 2019' (Human Rights Commission of Pakistan, 2020), http://hrcp-web.org/ hrcpweb/wp-content/uploads/2020/04/REPORT_State-of-HumanRights-in-2019-20190503.pdf.

${ }^{49}$ Ayesha Khan, 'Women Empowerment Leaders Rely on Their Involvement and Experience with Civil Society Organisations.', Institute of Development Studies, Policy Briefing, no. 172 (January 2021): 4.

${ }^{50}$ Adrian Shahbaz and Allie Funk, 'Freedom on the Net 2020: The Pandemic's Digital Shadow'. 
${ }^{51}$ Aamir Latif, 'Pakistan: Experts Say Too Early to Declare Victory against Virus', Anadolu Agency, 16 July 2020, https://www.aa.com.tr/en/ asia-pacific/pakistan-experts-say-too-early-to-declare-victory-againstvirus/1912253.

${ }^{52}$ Bakhtawar Mian, 'Ehsaas Averted Catastrophe during Pandemic: Report', DAWN.COM, 24 March 2021, https://www.dawn.com/news/1614205.

${ }^{53}$ Now Generation Network, 'Covid in Africa: What Does It Mean for Young People?' (Mo Ibrahim Foundation, July 2020), https://mo.ibrahim. foundation/sites/default/files/2020-07/ngn-survey-report.pdf.

${ }^{54}$ Kolapo Olapujo, 'Southern Kaduna: Conflict in a Pandemic (II): The Deserted Villages', TheCable, 6 October 2020, https://www.thecable. $\mathrm{ng} /$ conflict-in-a-pandemic-ii-the-deserted-villages-of-southern-kadunawhere-only-the-brave-dare-reside.

${ }^{55}$ CSSR Research team, Interview with Farooq Kubdani, 12 August 2020.

${ }^{56}$ ReliefWeb, 'Pakistan: Floods and Landslides - Aug 2020', ReliefWeb, August 2020, https://reliefweb.int/disaster/fl-2020-000185-pak-0.

${ }^{57}$ André Baptista, 'Watch: Why Are Cyclone Idai Victims Protesting in Beira, Mozambique?', Mozambique, 31 August 2020, https:// clubofmozambique.com/news/watch-why-are-cyclone-idai-victimsprotesting-in-beira-mozambique-170226/.

${ }^{58}$ Olatokewa Ayoade, 'The Economic Repercussion of Coronavirus Pandemic on Nigerians', Pulitzer Center, 11 June 2020, https://pulitzercenter.org/ stories/economic-repercussion-coronavirus-pandemic-nigerians.

${ }^{59}$ Anadolu Agency, 'Nigeria: Arrests in Protests against Fuel Price Hike', 10 September 2020, https://www.aa.com.tr/en/africa/nigeria-arrestsin-protests-against-fuel-price-hike/1969344.

${ }^{60}$ Shadi Khan Saif, 'Pakistan: Stranded Afghans Flood Border amid Pandemic', Anadolu Agency, 7 April 2020, https://www.aa.com. tr/en/asia-pacific/pakistan-stranded-afghans-flood-border-amidpandemic/1796014.

${ }^{61}$ Baqir Sajjad Syed, 'Bajwa Calls for National Unity to Fight Covid-19', DAWN.COM, 2 April 2020, https://www.dawn.com/news/1545740.

${ }^{62} \mathrm{M}$. M. O. Notícias, 'Agente da polícia assassinado por dois polícias em Nampula - MMO', 31 July 2020, https://noticias.mmo.co.mz/2020/07/ agente-da-policia-assassinado-por-dois-policias-em-nampula.html.

${ }^{63}$ National Human Rights Commission, 'Report of Alleged Human Rights Violations Recorded Between 13th April to 4th May, 2020 Following the Extention of the Lockdown Period' (National Human Rights Commission Nigeria, 10 May 2020), https://www.nigeriarights.gov.ng/nhrc-media/ press-release/104-report-of-alleged-human-rights-violations-recordedbetween-13th-april-to-4th-may-2020-following-the-extension-of-thelockdown-period.html.

${ }^{64}$ Ruth Olurounbi, 'Nigerian Security Response to Covid Is Deadlier Than the Disease', Bloomberg.Com, 5 July 2020, https://www.bloomberg. com/news/articles/2020-07-05/nigerian-security-response-to-covid-isdeadlier-than-the-disease.

${ }^{65}$ Kingsley Omonobi, 'FCT Police Did Not Arrest Protesters over Revolution Now in Abuja - CP', Vanguard News, 5 August 2020, https:// www.vanguardngr.com/2020/08/fct-police-did-not-arrest-protestersover-revolution-now-in-abuja-cp/.

${ }^{66} \mathrm{ANI}$, 'Imran Khan Urges Opposition to Not Hold Lahore Rally, Says Gathering Leads to Spread of COVID-19', ANI News, sec. World, accessed 15 April 2021, https://www.aninews.in/news/world/asia/imrankhan-urges-opposition-to-not-hold-lahore-rally-says-gathering-leadsto-spread-of-covid-1920201210231517/; Jamil Nagri, 'Imran Slams PDM Rallies amid Spike in Covid Cases', DAWN.COM, 3 December 2020, https://www.dawn.com/news/1593683.

${ }^{67}$ Mudiaga Affe, 'Nigeria: Edo Election - APC, PDP Flout Covid-19 Guidelines in Campaigns', AllAfrica.Com, 16 September 2020, sec. News, https://allafrica.com/stories/202009160808.html.
${ }^{68}$ Omeiza Ajayi, 'COVID-19 Protocol: FCT Releases 40 \#RevolutionNow Protesters', Vanguard News, 5 August 2020, https://www.vanguardngr. com/2020/08/covid-19-protocol-fct-releases-40-revolutionnow-protesters/.

${ }^{69}$ CSW, 'Nigeria: At Least 33 Killed in Southern Kaduna State despite 24-Hour Curfew', CSW, 7 August 2020, https://www.csw.org. uk/2020/08/07/press/4755/article.htm.

${ }^{70}$ Jaffer A. Mirza, 'The Changing Landscape of Anti-Shia Politics in Pakistan', 28 September 2020, https://thediplomat.com/2020/09/thechanging-landscape-of-anti-shia-politics-in-pakistan/.

${ }^{71}$ Nagri, 'Imran Slams PDM Rallies amid Spike in Covid Cases'.

${ }_{72}$ MISA, 'A Year without Ibraimo Mbaruco', 7 April 2021, https://www. misa.org.mz/index.php/destaques/noticias/109-um-ano-sem-ibraimombaruco.

${ }^{73}$ Imtiaz Ali, 'Express Tribune Journalist Bilal Farooqi Arrested in Karachi for "Defaming Pakistan Army"', DAWN.COM, 11 September 2020, https://www.dawn.com/news/1579118.

${ }^{74}$ Spaces for Change, '\#EndSARS: POLICE BRUTALITY, PROTESTS AND SHRINKING CIVIC SPACE IN NIGERIA' (Spaces for Change, 22 March 2021), 73, https://closingspaces.org/endsars-police-brutality-protestsand-shrinking-civic-space-in-nigeria/.

${ }^{75}$ Nádia Issufo, 'Covid-19: Estado de calamidade pública declarado em Moçambique | DW | 04.09.2020', DW.COM, 4 September 2020, https:// www.dw.com/pt-002/covid-19-estado-de-calamidade-p\%C3\%BAblicadeclarado-em-mo\%C3\%A7ambique/a-54822206.

${ }^{76}$ Fund for Global Human Rights, 'Nigerian Civil Society Pushes Back on Draconian Disease Bill', The Fund for Global Human Rights (blog), 21 May 2020, https://globalhumanrights.org/en_gb/blogs/nigerian-civilsociety-pushes-back-on-draconian-disease-bill/.

${ }^{77}$ Khan, 'Navigating Civic Space Baseline Report - Pakistan'.

${ }^{78}$ Saadia Salahuddin, 'All NGOs Asked to Register with Punjab Charity Commission', The News International, 3 July 2020, https://www. thenews.com.pk/print/681353-all-ngos-asked-to-register-with-punjabcharity-commission.

${ }^{79}$ Spaces for Change, 'PRESS STATEMENT: Civil Society Groups Demand Urgent Review of CAMA 2020', Spaces for Change (blog), 25 August 2020, https://spacesforchange.org/august-25-2020-press-statement-civilsociety-groups-demand-urgent-review-of-cama-2020/.

${ }^{80}$ Spaces for Change, '\#EndSARS'.

${ }^{81}$ Ammar Ali Jan, 'Students on the March', The News International, 27 November 2020, https://www.thenews.com.pk/print/749751students-on-the-march.

${ }^{82}$ Ammar Ali Jan, 'Rule of Fear and Symbols of Hope', The News International, 4 December 2020, https://www.thenews.com.pk/ print/753251-rule-of-fear-and-symbols-of-hope.

${ }^{83}$ Tosin Adams, '\#EndSARS Protester, Eromosele, Allegedly Arrested in Lagos', The Guardian Nigeria News - Nigeria and World News, 10 November 2020, https://guardian.ng/news/endsars-protestereromosele-allegedly-arrested-in-lagos/.

${ }^{84}$ Spaces for Change, '\#EndSARS'.

${ }^{85}$ Kolapo Olapujo, 'Southern Kaduna'.

${ }^{86}$ Success Nwogu, 'Villa Coverage: PDP, CSOs Knock Buhari for barring PUNCH, Others', Punch Newspapers (blog), 26 March 2020, https://punchng. com/villa-coverage-pdp-csos-knock-buhari-for-barring-punch-others/.

${ }^{87}$ Spaces for Change, 'NBC Sanctions AriseTV, Channels, AIT for \#EndSARS Coverage', Closing Spaces, 27 October 2020, https://closingspaces.org/6375-2/.

${ }^{88}$ Amnesty International, 'Moçambique: Ataque Ao Jornal Canal Deve Ser Investigado de Imediato', Amnistia Internacional Portugal (blog), 31 August 2020, https://www.amnistia.pt/mocambique-ataque-ao-jornalcanal-deve-ser-investigado-de-imediato/. 
${ }^{89}$ Patricia Gossman, 'Online Harassment', DAWN.COM, 22 October 2020, https://www.dawn.com/news/1586411; 'Letter from Women of Pakistan to the State of Pakistan', accessed 16 April 2021, https:// docs.google.com/document/d/1bWUER2z1cSLj8mtBI_NnmaZHMGb6jUFGOlolN19hHQ/edit?usp=embed_facebook.

${ }^{90}$ The News International, 'PFUJ Concerned over Fictitious Cases against 49 Journalists', The News International, 26 September 2020, https:// www.thenews.com.pk/print/720376-pfuj-concerned-over-fictitiouscases-against-49-journalists.

${ }^{91}$ DAWN, 'Outcry over Rangers "Raid" on Karachi Press Club', DAWN. COM, 28 July 2020, https://www.dawn.com/news/1571551.

${ }^{92}$ MISA, 'On the Pronouncements of the PR: MISA Mozambique Concerned about the Risk of a New Wave of Persecutions against Journalists in Cabo Delgado', MISA, 26 November 2020, https:// www.misa.org.mz/index.php/destaques/noticias/105-sobre-ospronunciamentos-do-pr-o-misa-mocambique-preocupado-com-o-riscode-uma-nova-onda-perseguicoes-contra-jornalistas-em-cabo-delgado.

${ }^{93}$ Ahmad Noorani, 'Ahmad Noorani on Twitter', Twitter, 30 August 2020, https://twitter.com/Ahmad Noorani/status/1299957765104951297.

${ }^{94}$ Spaces for Change, '\#EndSARS'.

${ }^{95}$ CSSR Research Team, Telephone interview with Benazir Shah, 24 December 2020

${ }^{96}$ CSSR Research Team, Correspondance with Ailia Zehra, 17 October 2020.

${ }^{97}$ Gossman, 'Online Harassment'.

${ }^{98}$ Ayesha Khan, Aslam Khwaja, and Asiya Jawed, 'Navigating Civic Spaces During a Pandemic Pakistan Report'.

${ }^{99}$ Sindhu Abbasi, 'Explainer: Pakistan's New Social Media Rules | SAMAA' Samaa TV, 20 November 2020, https://www.samaa.tv/news/2020/11/ explainer-pakistans-new-social-media-rules/.

${ }^{100}$ Salman Masood, 'Pakistan Bans TikTok, Citing Morals. Others Cite Politics.', The New York Times, 11 October 2020, sec. Technology, https:// www.nytimes.com/2020/10/11/technology/tiktok-pakistan-ban.html.

${ }^{101}$ Hasnaat Malik, 'Supreme Court Hints at Banning YouTube', The Express Tribune, 22 July 2020, sec. Pakistan, http://tribune.com.pk/ story/2256150/supreme-court-hints-at-banning-youtube.

${ }^{102}$ Asad Hashim, 'Pakistan's New Regulations Aim to "Silence the Internet"', 2 December 2020, https://www.aljazeera.com/ news/2020/12/2/pakistans-new-regulations-aim-to-silence-the.

${ }^{103}$ Victoria Ibezim-Ohaeri, 'Galvanizing Collective Action To Protect The Civic Spave in Nigeria' (Spaces for Change, 13 March 2021), 12, https:// yaraduafoundation.org/files/Galvanizing\%20Collective\%20Action.pdf.

${ }^{104}$ Vanguard News, 'DSS Must Release Emperor Ogbonna from Illegal Custody Now - FALANA', Vanguard News, 19 July 2020, https://www. vanguardngr.com/2020/07/dss-must-release-emperor-ogbonna-fromillegal-custody-now-falana/.

${ }^{105}$ Lúcio Posse and Egídio Chaimite, 'Perceptions of Covid-19 in Mozambique and the Influence of "Intermediaries"', Institute of Development Studies (blog), 12 November 2020, https://www.ids.ac.uk/ opinions/perceptions-of-covid-19-in-mozambique-and-the-influenceof-intermediaries/.

106 Jaffer A. Mirza, 'Pakistan's Hazara Shia Minority Blamed for Spread of Covid-19', Institute of Development Studies (blog), 17 April 2020, https:// www.ids.ac.uk/opinions/pakistans-hazara-shia-minority-blamed-forspread-of-covid-19/.

${ }^{107}$ Hannah Ellis-Petersen and Shah Meer Baloch, 'Pakistan Coronavirus Camp: "No Facilities, No Humanity"', The Guardian, 19 March 2020, sec. World news, http://www.theguardian.com/world/2020/mar/19/ pakistan-coronavirus-camp-no-facilities-no-humanity.
${ }^{108}$ CSW, 'Nigeria'.

${ }^{109}$ CSSR Research Team, Interview with Nasir Mansoor., 3 November 2020.

${ }^{110}$ News Desk, 'Anti-Shia Wall Chalking Surfaces On Karachi Streets', Naya Daur, 3 September 2020, https://nayadaur.tv/2020/09/anti-shia-wallchalking-surfaces-on-karachi-streets/.

${ }^{111}$ Ayesha Khan, Aslam Khwaja, and Asiya Jawed, 'Navigating Civic Spaces During a Pandemic Pakistan Report'.

${ }^{112}$ Gandhara, 'Rights Bodies Alarmed Over Surge In Pakistan's Blasphemy Cases', RFE/RL, 2020, https://gandhara.rferl.org/a/rights-bodiesalarmed-over-surge-in-pakistan-s-blasphemy-cases/30825288.html.

${ }^{113}$ ANI News, 'Pak Ex-Foreign Minister Khawaja Asif Facing Blasphemy Charges Speaking for Religious Equality', ANI News, 14 July 2020, sec. World, https://www.aninews.in/news/world/asia/pak-ex-foreignminister-khawaja-asif-facing-blasphemy-charges-speaking-for-religiousequality20200714154322/.

${ }^{114}$ Opinion Nigeria, 'Mubarak Bala: 300 Days in Detention Without Trial -By Leo Igwe', Opinion Nigeria (blog), 23 February 2021, https:// opinionnigeria.com/mubarak-bala-300-days-in-detention-without-trialby-leo-igwe/.

${ }^{115}$ Ermi Ndoen et al., 'Existing Political Tensions Intensify during Pandemic: A "glocal" Observation', The Conversation, 1 October 2020, http://theconversation.com/existing-political-tensions-intensifyduring-pandemic-a-glocal-observation-146677; Hassan Javid, Sameen M. Ali, and Umair Javed, 'Factional Federalism, State Capacity, and Fiscal Constraints: Pakistan's COVID-19 Challenges', South Asia@LSE (blog), 3 April 2020, https://blogs.lse.ac.uk/southasia/2020/04/03/factionalfederalism-state-capacity-and-fiscal-constraints-pakistans-covid-19challenges/; The Economist, 'Across the World Central Governments Face Local Covid-19 Revolts', The Economist, 12 October 2020, https:// www.economist.com/international/2020/10/12/across-the-worldcentral-governments-face-local-covid-19-revolts; Shandana Khan Mohmand et al., 'Governance for Building Back Better', IDS Bulletin 52, no. 1 (23 March 2021), https://doi.org/10.19088/1968-2021.113.

${ }^{116}$ Imran Ayub, '18th Amendment Needs to Be "Reviewed": PM', DAWN. COM, 18 June 2020, https://www.dawn.com/news/1564273.

${ }^{117}$ Madiha Afzal, 'Pakistan Teeters on the Edge of Potential Disaster with the Coronavirus', Brookings (blog), 27 March 2020, https://www. brookings.edu/blog/order-from-chaos/2020/03/27/pakistan-teeterson-the-edge-of-potential-disaster-with-the-coronavirus/.

${ }^{118}$ Spaces for Change, 'Navigating Civic Space in a Time of Covid-19: Nigeria Report'; The Guardian, 'CSOs Accuse FG of Excluding Niger Delta from COVID-19 Interventions', The Guardian Nigeria News - Nigeria and World News (blog), 22 April 2020, https://guardian.ng/news/csosaccuse-fg-of-excluding-niger-delta-from-covid-19-interventions/.

${ }^{119}$ Amy Dodd, Dean Breed, and Daniel Coppard, 'How Is Aid Changing under Covid-19', Development Initiatives (blog), November 2020, https://devinit.org/resources/how-aid-changing-covid-19-pandemic/.

${ }^{120}$ CIVICUS, 'People Power Under Attack 2020'.

${ }^{121}$ Bülow, 'The Impacts of the Pandemic on Digital Activism'.

${ }^{122}$ Berndt, 'Peopleless Protest'; Toyana, 'Hashtags and Spectacles: Zimbabwe's Feminist Activists Find Online Avenues to Tackle Government's COVID-19 Clampdown'; Ciobanu, 'Poles Find Creative Ways to Protest Despite the Pandemic'.

${ }^{123}$ Spaces for Change, '\#EndSARS'.

${ }^{124}$ Saskia Brechenmacher, Thomas Carothers, and Richard Youngs, 'Civil Society and the Coronavirus: Dynamism Despite Disruption', Carnegie Endowment for International Peace, 21 April 2020, https:// carnegieendowment.org/2020/04/21/civil-society-and-coronavirusdynamism-despite-disruption-pub-81592; Youngs, 'Coronavirus as a Catalyst for Global Civil Society'. 
${ }^{125}$ DAWN Staff reporter, 'Medics, Health Workers Protest "NonProvision" of PPE in Lahore', DAWN.COM, 28 April 2020, https://www. dawn.com/news/1552721.

${ }^{126}$ DW, 'Covid-19: Mozambican Doctors to Sue Government', DW.COM, October 2020, https://clubofmozambique.com/news/covid-19mozambican-doctors-to-sue-government-dw-175658/.

${ }^{127}$ Olawale Ajimotokan, 'Nigeria: FG Pays N4.6 Billion Hazard Allowance to 55,031 Health Workers', AllAfrica.Com, 22 June 2020, sec. News, https://allafrica.com/stories/202006220952.html.

${ }^{128}$ Spaces for Change, 'Navigating Civic Space in a Time of Covid-19: Nigeria Report'.

${ }^{129}$ Brechenmacher, Carothers, and Youngs, 'Civil Society and the Coronavirus'; Youngs, 'Coronavirus as a Catalyst for Global Civil Society'.

${ }^{130}$ Brechenmacher, Carothers, and Youngs, 'Civil Society and the Coronavirus'.

${ }^{131}$ Abigail Bellows and Nada Zohdy, 'Is the Coronavirus Catalyzing New Civic Collaborations for Open Government?' (Carnegie Endowment for International Peace, 23 November 2020), https://carnegieendowment. org/2020/11/23/is-coronavirus-catalyzing-new-civic-collaborations-foropen-government-pub-83289.

${ }^{132}$ CACOVID, 'Coalition Against Covid-19', 2020, https://www.cacovid. org/.

${ }^{133}$ S4C Research Team, Interview with Father Raymond Anuliefo, Lagos, 7 December 2020.

134 IESE Research Team, Interview with member of National Human Rights Pressure (PNDH), Sofala, 21 January 2021.

${ }^{135}$ ANEEJ, 'Covid 19: 748,684 Households Received N16.3billion from Recovered \$322.5million Abacha Loot -MANTRA Report', ANEEJ (blog), 18 June 2020, https://www.aneej.org/covid-19-748684-householdsreceived-n16-3billion-from-recovered-322-5million-abacha-lootmantra-report/.

${ }^{136}$ Alfredo Junior, 'Sociedade civil moçambicana exige contas certas na resposta à Covid-19', VOA, 28 July 2020, https://www. voaportugues.com/a/sociedade-civil-exige-contas-certas-na-reposta-àcovid-19/5521104.html; Forum De Monitoria Do Orcamento, 'Monitoria e Rastreio Mostra Que Pouco Dinheiro Foi Alocado Às Províncias e Às Famílias' (Forum De Monitoria Do Orcamento, December 2020), https:// omrmz.org/omrweb/wp-content/uploads/FMO-Monitoria-e-rastreiomostra-que-pouco-dinheiro-foi-alocado-as-provincias-e-as-familias.pdf.

${ }^{137}$ Andre Baptista, 'Vítimas do ciclone Idai protestam contra atraso de subsídios na Beira', VOA, 29 August 2020, https://www.voaportugues. com/a/vítimas-do-ciclone-idai-protestam-contra-atraso-de-subsídiosna-beira/5562354.html.

138 The News International, 'MDCAT 2020: Students Voice Anger on Twitter, Demand PMC to Postpone Exam beyond Nov 29', The News International, 25 November 2020, https://www.thenews.com.pk/ latest/749104-mdcat-2020-students-voice-anger-on-twitter-demandpmc-to-postpone-exam-beyond-nov-29.

${ }^{139}$ Chukwuma Muanya and lyabo Lawal, 'School Resumption Raises Fresh Concerns', The Guardian Nigeria News - Nigeria and World News, 1 September 2020, https://m.guardian.ng/news/school-resumptionraises-fresh-concerns/.

${ }^{140}$ ROSC, 'Em Tempos Da COVID-19 Proteger as Crianças Do Trabalho Infantil é Um Imperativo', The ROSC, 30 August 2020, http://www.rosc org.mz/index.php/noticias/86-em-tempos-da-covid-19-proteger-ascriancas-do-trabalho-infantil-e-um-imperativo.

${ }^{141}$ Zia Ur Rehman, ‘Balochistan's Students Seek Internet Access for Online Classes', The News International, 12 June 2020, https://www. thenews.com.pk/print/671357-balochistan-s-students-seek-internetaccess-for-online-classes.
${ }^{142}$ Ammar Ali Jan, 'Students on the March'.

${ }^{143}$ Anadolu Agency, 'Nigeria'.

${ }^{144}$ Alfred Olufemi, 'October 1: \#RevolutionNow Organisers Call for Nationwide Protest', 25 September 2020, https://www. premiumtimesng.com/news/more-news/416862-october-1revolutionnow-organisers-call-for-nationwide-protest.html.

${ }^{145}$ Spaces for Change, '\#EndSARS'.

146 UNFPA, 'COVID-19: A Gender Lens- Protecting Sexual and Reproductive Health and Rights and Promoting Gender Equality' (UNFPA, March 2020), 1, https://www.unfpa.org/sites/default/files/resourcepdf/COVID-19_A_Gender_Lens_Guidance_Note.pdf.

147 UNDP, 'UNDP Brief Gender Based Violence and COVID 19' (UNDP, May 2020), https://www.undp.org/content/undp/en/home/ librarypage/womens-empowerment/gender-based-violence-andcovid-19.html; UNFPA, 'COVID-19: A Gender Lens- Protecting Sexual and Reproductive Health and Rights and Promoting Gender Equality'; Amber Peterman and Megan O'Donnell, 'COVID-19 and Violence against Women and Children: A Second Research Round Up - World' (Centre for Global Development, 23 September 2020), https:// reliefweb.int/report/world/covid-19-and-violence-against-womenand-children-second-research-round.

${ }^{148}$ Ayesha Khan, Aslam Khwaja, and Asiya Jawed, 'Navigating Civic Spaces During a Pandemic Pakistan Report'

${ }^{149}$ Abdur Rahman Alfa Shaban, 'Nigerians Protest Rising Sexual Violence: On Streets, Social Media', Africanews, 21 June 2020, https://www. africanews.com/2020/06/21/nigerians-protest-rising-sexual-violenceon-streets-social-media/.

${ }^{150}$ FIDA, 'FIDA Nigeria Cries Out Against the Rise in Gender Based Violence', FIDA (blog), 3 June 2020, https://fida.org.ng/2020/06/fidanigeria-cries-out-against-the-rise-in-gender-based-violence/.

151 This Day Live, 'Rape Allegation: Over 11,000 Sign Petition to Remove D'banj as UN Youth Ambassador', THISDAYLIVE (blog), 19 June 2020, https://www.thisdaylive.com/index.php/2020/06/19/rapeallegation-over-11000-sign-petition-to-remove-dbanj-as-un-youthambassador/.

${ }^{152}$ Amnesty International, 'Moçambique: Vídeo Com Execução de Mulher Prova Mais Uma Vez Violações de Direitos Humanos Pelas Forças Armadas', Amnistia Internacional Portugal (blog), 15 September 2020, https://www.amnistia.pt/mocambique-video-com-execucaode-mulher-prova-mais-uma-vez-violacoes-de-direitos-humanos-pelasforcas-armadas/.

${ }^{153}$ PLAC, 'Senate Passes Sexual Harassment Bill, 2020 - Policy and Legal Advocacy Centre', Policy and Legal Advocacy Centre (blog), 8 July 2020, https://placng.org/i/senate-passes-sexual-harassment-bill-2020/.

${ }^{154}$ Saroop ljaz, 'Beginning of the End for "Virginity Exams" in Pakistan?', Human Rights Watch (blog), 14 October 2020, https://www.hrw.org/ news/2020/10/14/beginning-end-virginity-exams-pakistan.

155 Gossman, 'Online Harassment'.

156 ILO, 'Social Protection Responses to the COVID 19 Pandemic in Developing Countries Strengthening Resilience by Building Universa Social Protection' (ILO, May 2020), https://www.ilo.org/wcmsp5/ groups/public/---ed_protect/---soc_sec/documents/publication/ wcms 744612.pdf.

${ }^{157}$ World Bank, Poverty and Shared Prosperity 2020: Reversals of Fortune (The World Bank, 2020), https://doi.org/10.1596/978-14648-1602-4.

${ }^{158}$ Staff Author, 'Protest Campaign Planned against Deep-Sea Fishing Trawlers', DAWN.COM, 3 September 2020, https://www.dawn.com/ news/1577579. 
${ }^{159}$ International Federation of Journalists, 'Pakistan: State-Owned Radio Pakistan Sacks 749 Media Workers', International Federation of Journalists, 22 October 2020, https://www.ifj.org/media-centre/news/ detail/category/press-releases/article/pakistan-state-owned-radiopakistan-sacks-749-media-workers.html.

160 Hamid Riaz, 'Workers Decry Unplanned Closure of Brick Kilns', Voicepk. Net (blog), 3 November 2020, https://voicepk.net/2020/11/03/ workers-decry-unplanned-closure-of-brick-kilns/.

${ }^{161}$ Ary News, 'Nanbais' Strike for Hike in Price Enters 12th Day', ARY NEWS (blog), 2 November 2020, https://arynews.tv/en/nanbais-strikequetta-12-day/.

162 The News International, 'Silenced Protests', The News International, 7 November 2020, https://www.thenews.com.pk/print/740008-silencedprotests.

${ }^{163}$ Shazia Hasan, 'Workers' Rally Slams Govt's Policies, Seeks End to "Protection of Major Investors"', DAWN.COM, 30 November 2020, https://www.dawn.com/news/1593134.

${ }^{164}$ Angela Ukomadu, 'Nigeria's Main Unions Suspend Planned Strike after Government Talks', Reuters, 28 September 2020, https://www.reuters. com/article/health-coronavirus-nigeria-strike-idINKBN26JOFK.

165 DAWN Staff reporter, 'Farmers Postpone Protest after Baton-Charge, Arrests', DAWN.COM, 5 November 2020, https://www.dawn.com/ news/1588687.

${ }^{166}$ Shazia Hasan, 'Boat Rally Taken out to Oppose Development of Cities on Islands', DAWN.COM, 16 October 2020, https://www.dawn.com/ news/1585307.

${ }^{167}$ Fidelis Mbah, 'Nigeria Seeks to Halt Looting amid Fury over "Food Warehouses"', Al Jazeera, 25 October 2020, https://www.aljazeera. com/news/2020/10/25/nigeria-cracks-down-on-rising-mob-looting-onfood-warehouses.

${ }^{168}$ CTA, 'Positioning of the Private Sector Presented at the Press Conference on State Decree and Insecurity in Cabo Delgado', 2020, https://cta.org.mz/posicionamento-do-sector-privado-apresentado-naconfereencia-de-imprensa-sobre-o-decreto-de-estado-de-calamidadepublica-e-a-inseguranca-em-cabo-delgado/.

${ }^{169}$ Aaron, 'Coronavirus Shows the Need for a Human Rights-Based Approach to Public Health Crises'.

${ }^{170}$ Club of Mozambique, 'Mozambique: Beira Wakes up to Deserted Streets as Protest against Kidnappings Begins', Club of Mozambique, 23 October 2020, https://clubofmozambique.com/news/mozambiquebeira-wakes-up-to-deserted-streets-as-protest-against-kidnappingsbegins-175066/.

${ }^{171}$ RFE/RL, 'Pakistan Urged To Stop Online "Hate Campaigns” Against Critical Journalists', Gandhara, 15 January 2021, https://gandhara.rferl. org/a/reporters-without-borders-journalists-pakistan/31047413.html.

${ }^{172}$ Abdul Hai Kakar and Abubakar Siddique, 'One Family's Torment Showcases A Region's Suffering In Pakistan', RFE/RL, August 2020, https://gandhara.rferl.org/a/one-family-s-torment-showcases-aregion-suffering/30791736.html.

${ }^{173}$ Radio Mashaal, 'Women In Remote Pakistani Region Demand Release Of Local Men', RFE/RL, 13 October 2020, https://gandhara.rferl.org/a/ pakistan-women-in-waziristan-stage-sit-in-protest-to-demand-releaseof-local-men/30891498.html.

${ }^{174}$ Alfred Olufemi, 'October 1 '.

175 Kingsley Omonobi, 'FCT Police Did Not Arrest Protesters over Revolution Now in Abuja - CP'.

${ }^{176}$ Spaces for Change, '\#EndSARS'.

177 Spaces for Change.
${ }^{178}$ Nazifa Alizada et al., 'Autocratization Turns Viral'.

${ }^{179}$ Institute of Development Studies, 'Minutes of NCS Cross-Synthesis Meeting December 2020', December 2020, 3.

${ }^{180}$ Melissa Leach et al., 'Post-Pandemic Transformations: How and Why COVID-19 Requires Us to Rethink Development', World Development 138 (February 2021): 105233, https://doi.org/10.1016/j. worlddev.2020.105233.

${ }^{181}$ Hossain N. with Nalini Khurana, Sohela Nazneen, Marjoke Oosterom, Patrick Schröder, and Alex Shankland2019 'Development Needs Society-The Implications of Civic Space for the Sustainable Development Goals'.

${ }^{182}$ UN Human Rights Office of the High Commissioner, 'OHCHR | End of Mission Statement by the United Nations Special Rapporteur on the Situation of Human Rights Defenders, Michel Forst on His Visit to Colombia, 20 November to 3 December 2018*' (UN Human Rights Office of the High Commissioner, 2018), https://www.ohchr.org/EN/ NewsEvents/Pages/DisplayNews.aspx?NewsID=23960\&LangID=E; International Federation for Human Rights, 'Azerbaijan: Crackdown on Human Rights Defenders Intensifies as Baku Games Approach' (International Federation for Human Rights, 2016), https://www. refworld.org/docid/553619694.html; Borgh and Terwindt, 'Shrinking Operational Space of NGOs - a Framework of Analysis'; Christian Davenport, 'State Repression and Political Order', Annual Review of Political Science 10, no. 1 (June 2007): 1-23, https://doi.org/10.1146/ annurev.polisci.10.101405.143216

${ }^{183}$ Rosemary McGee, 'An International NGO Representative in Colombia: Reflections from Practice', Development in Practice 20, no. 6 (2010): 636-48; Angela Christie and Duncan Green, 'The Case for an Adaptive Approach to Empowerment and Accountability Programming in Fragile Settings', 21 June 2019, https://opendocs.ids. ac.uk/opendocs/handle/20.500.12413/14556; Diana Koester et al., 'How Can Donors Improve Their Support to Gender Equality in Fragile Settings? Findings from OECD Research', Gender \& Development 24 no. 3 (1 September 2016): 353-73, https://doi.org/10.1080/1355207 4.2016.1240907

${ }^{184} \mathrm{OHCHR}$, 'Report of the Special Rapporteur on the Rights to Freedom of Peaceful Assembly and of Association', Advance unedited version (Geneva: Office of the Human Rights Commissioner of the United Nations, 2017); OHCHR, 'Report of the Special Rapporteur on the Situation of Human Rights Defenders', Report of the Special Rapporteur on the situation of human rights defenders to the UN General Assembly (Office of the Human Rights Commissioner of the United Nations, 2017), http://www.ohchr.org/EN/Issues/SRHRDefenders/Pages/ SRHRDefendersIndex.aspx; UN, 'Report of the Special Rapporteur on the Situation of Human Rights in Myanmar', Human rights situation that require the attention of the Council (New York: United Nations Human Rights Council, 2018)

${ }^{185}$ Naomi Hossain and Devangana Kalita, 'Moral Economy in a Global Era: The Politics of Provisions during Contemporary Food Price Spikes', The Journal of Peasant Studies 41, no. 5 (3 September 2014): 815-31, https://doi.org/10.1080/03066150.2014.895328. 


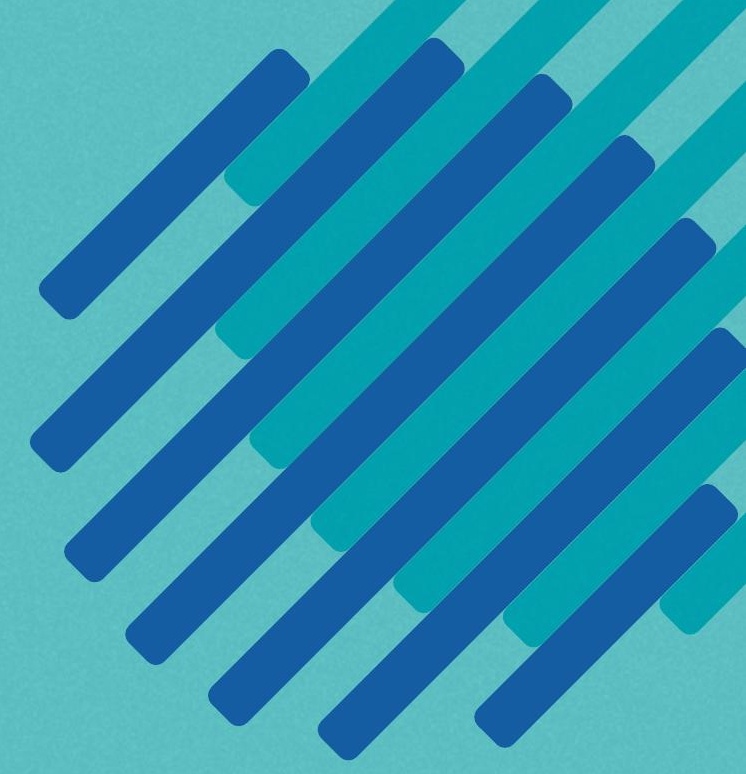


Produced as part of:

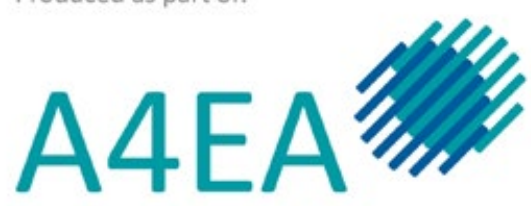

Action for empowerment and accountability research programme

Action for Empowerment and Accountability (A4EA) is an international research programme which explores how social and political action can contribute to empowerment and accountability in fragile, conflict, and violent settings, with a particular focus on Egypt, Mozambique, Myanmar, Nigeria and Pakistan.

Led by the Institute of Development Studies, A4EA is being implemented by a consortium that includes: the Accountability Research Center (ARC), the Collective for Social Science Research (CSSR), the Institute of Development and Economic Alternatives (IDEAS), Itad, Oxfam GB, and the Partnership for African Social and Governance Research (PASGR).

It is supported with UK aid from the UK Government.

The views expressed in this publication do not necessarily reflect the official policies of our funder.

www.ids.ac.uk/A4EA

@A4EA_Research 